\title{
MAP OF INDUSTRIAL MINERALS OCCURRENCES IN ALASKA
}

\author{
by \\ DeAnne S. Pinney and Emily S. Duenwald
}

September 2001

\author{
Alaska Division of Geological \& Geophysical Surveys \\ 794 University Avenue, Suite 200 \\ Fairbanks, Alaska 99709-3645
}

THIS REPORT HAS NOT BEEN REVIEWED FOR TECHNICAL CONTENT

OR FOR CONFORMITY TO THE EDITORIAL STANDARDS OF DGGS 


\title{
MAP OF INDUSTRIAL MINERAL OCCURRENCES IN ALASKA
}

\author{
by \\ DeAnne S. Pinney ${ }^{1}$ and Emily S. Duenwald ${ }^{1}$

\section{CONTENTS}

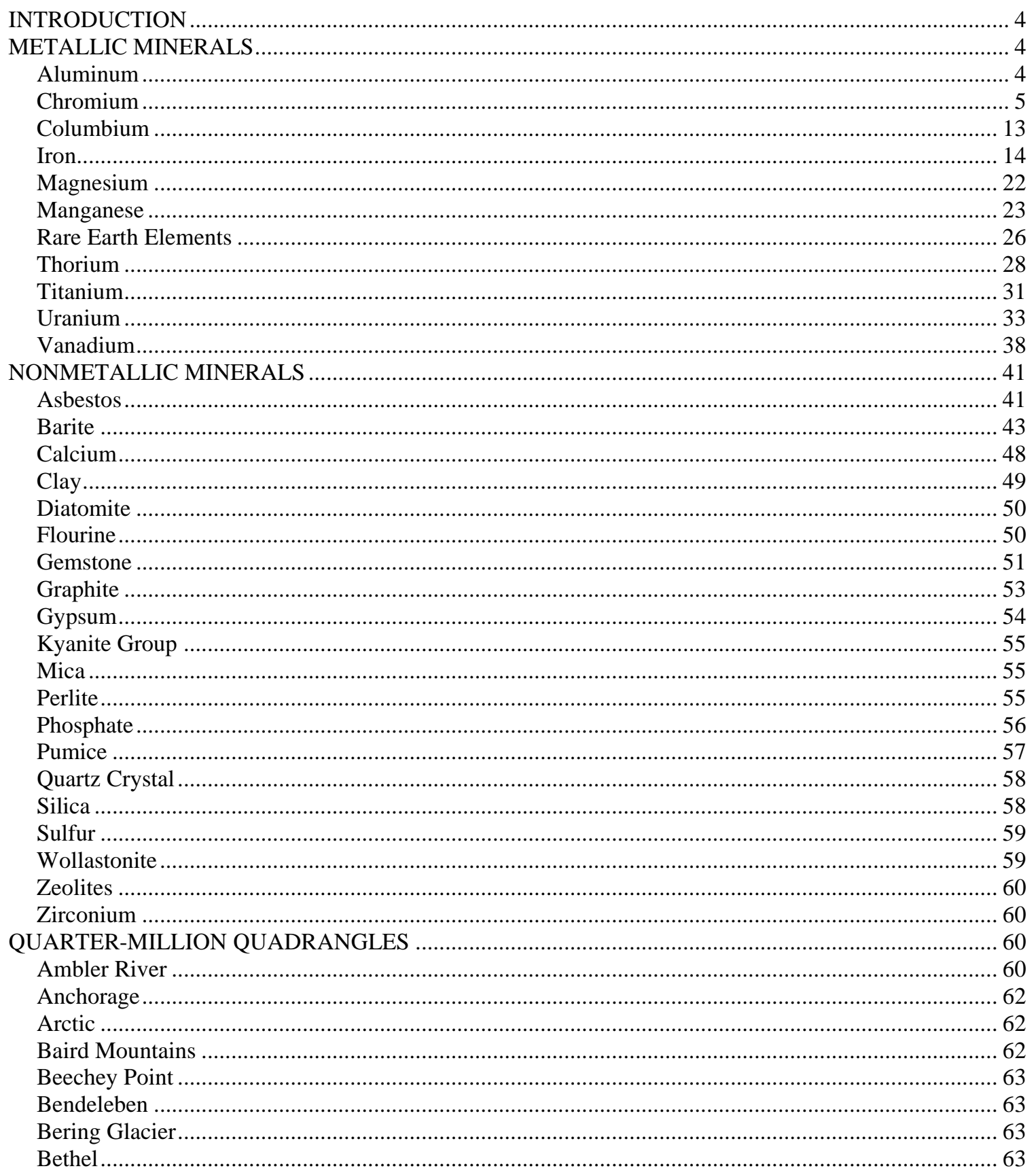

\footnotetext{
${ }^{1}$ Alaska Division of Geological \& Geophysical Surveys, 794 University Ave., Suite 200, Fairbanks, Alaska 99709-3645.
} 


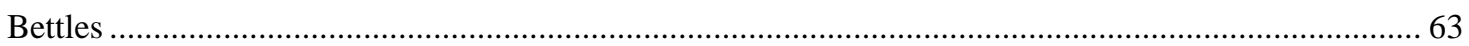

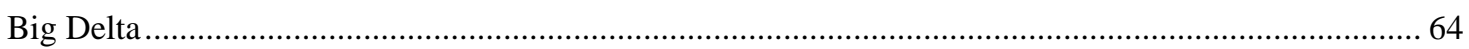

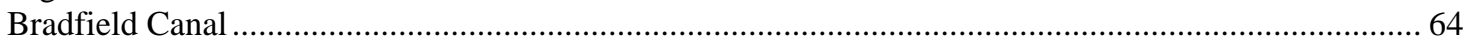

Candle

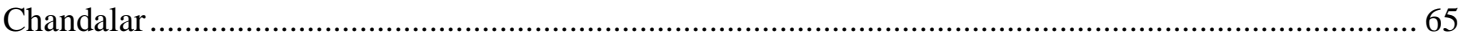

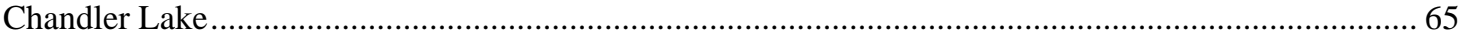

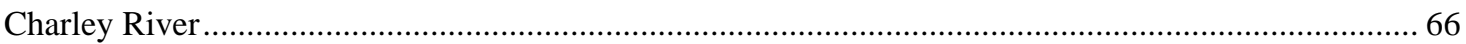

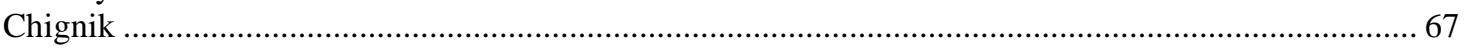

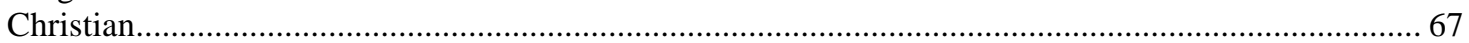

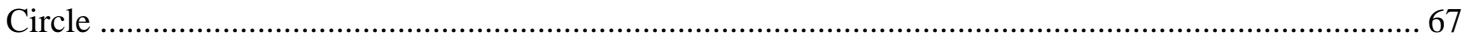

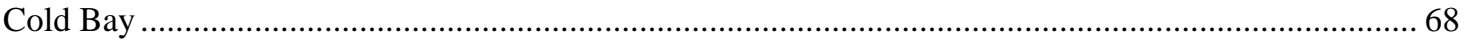

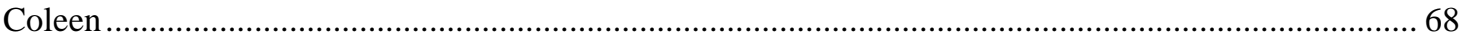

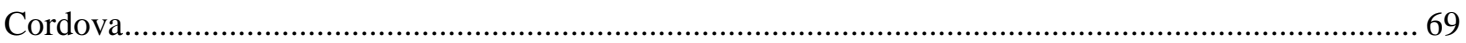

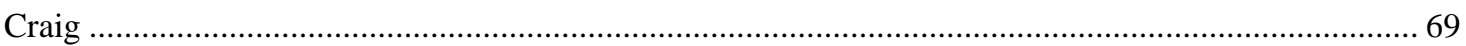

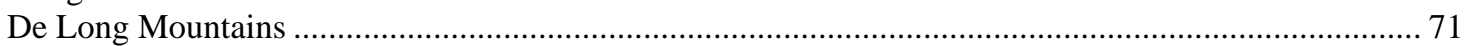

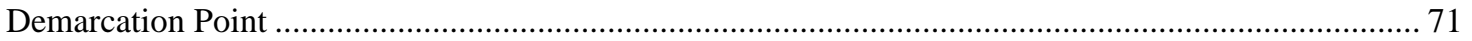

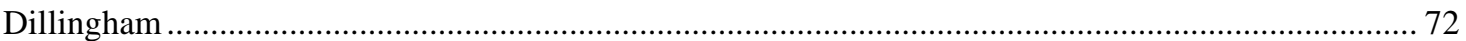

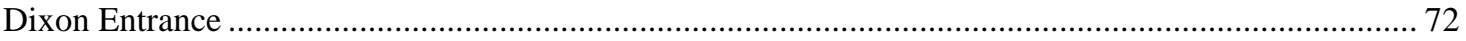

Eagle

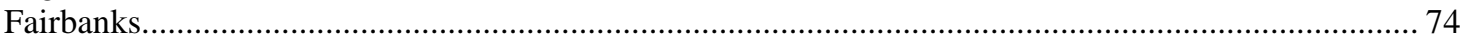

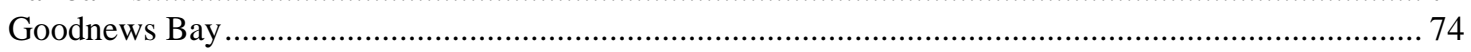

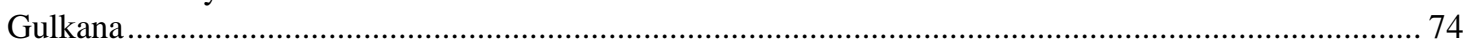

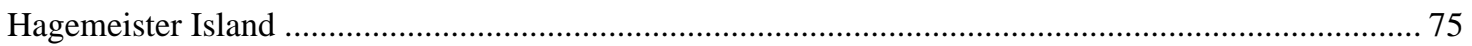

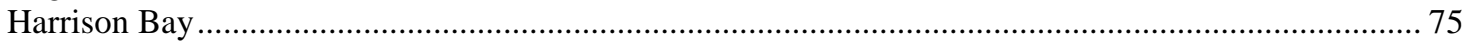

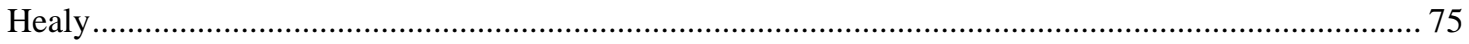

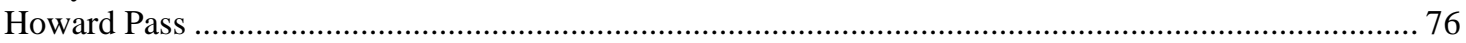

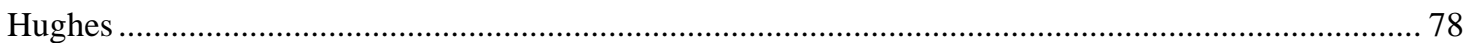

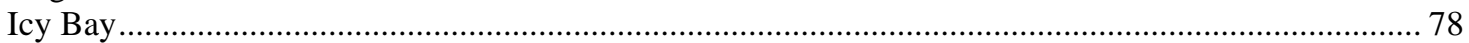

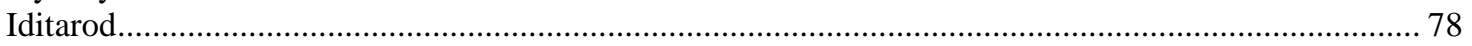

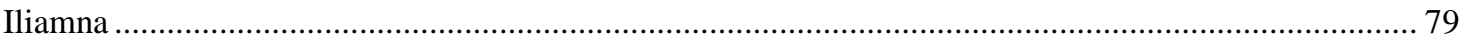

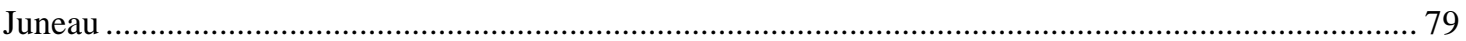

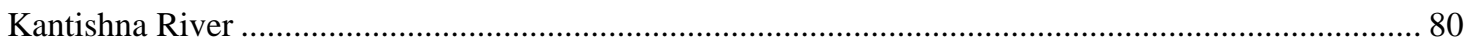

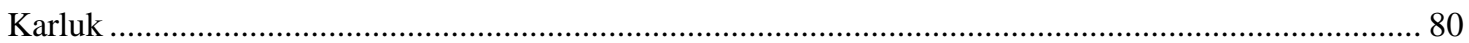

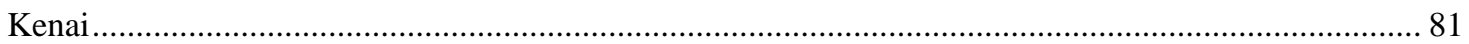

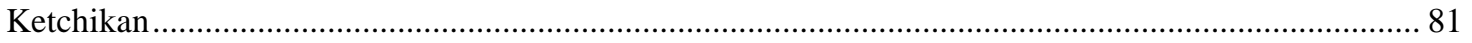

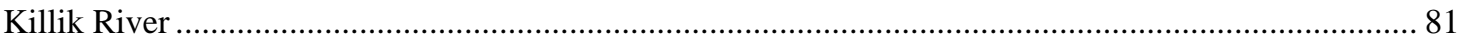

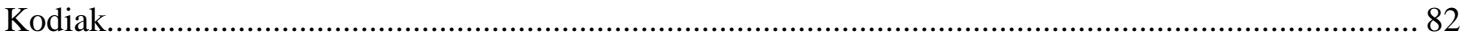

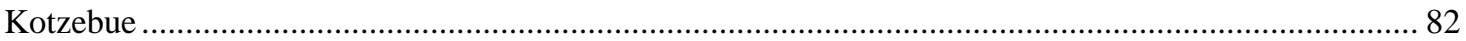

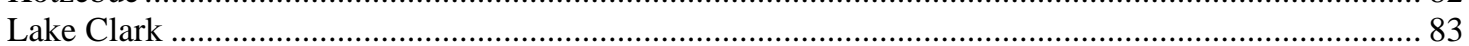

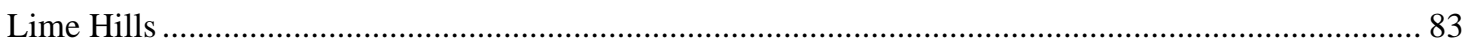

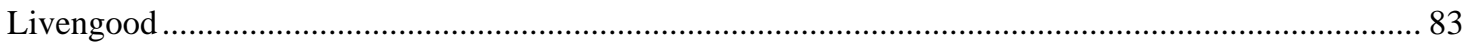

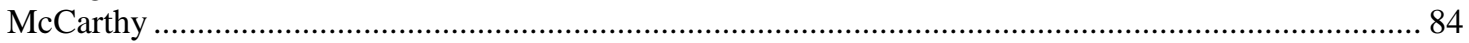

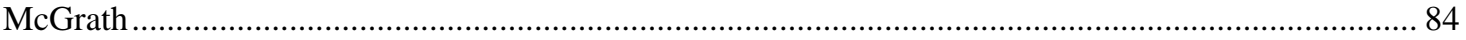

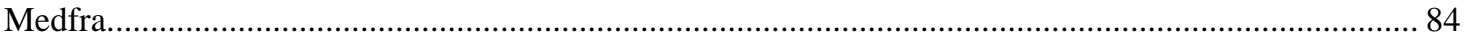

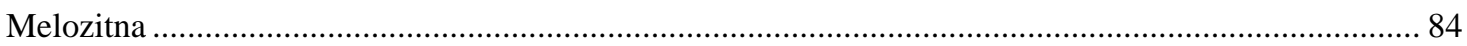

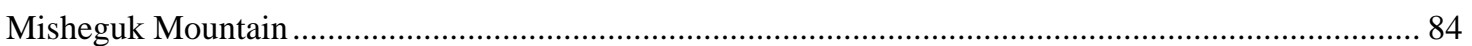

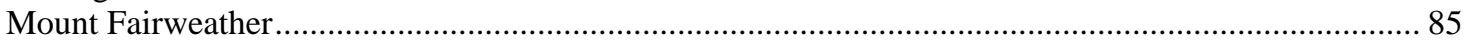

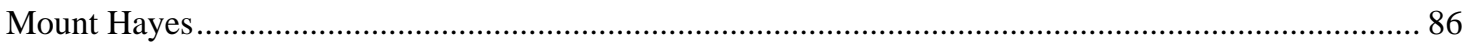

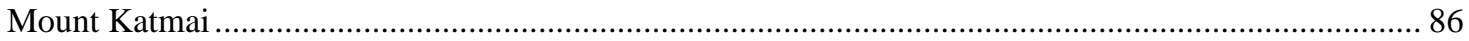

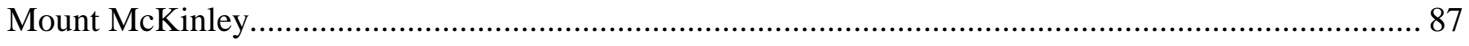

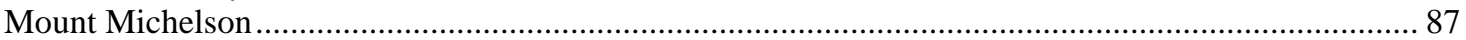

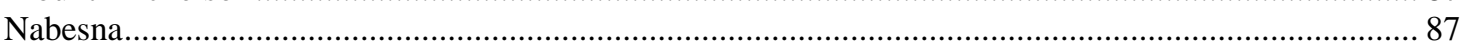

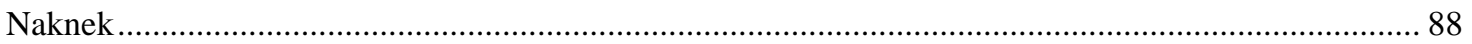

Noatak

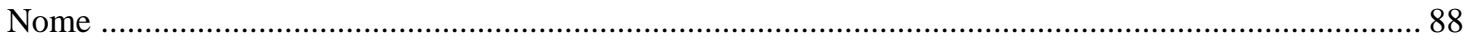

Nulato 


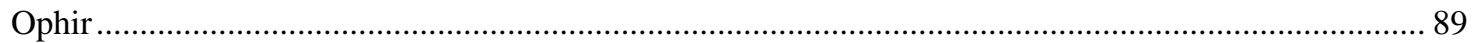

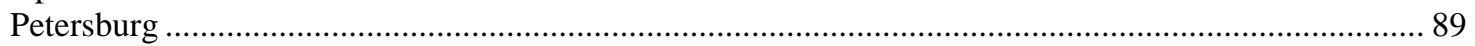

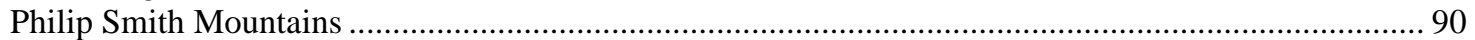

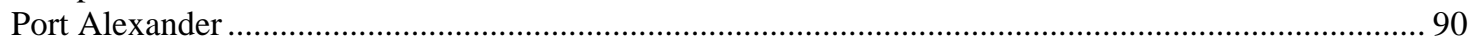

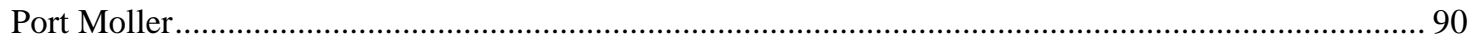

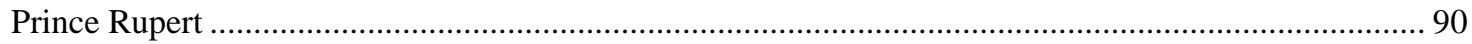

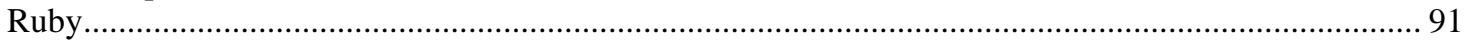

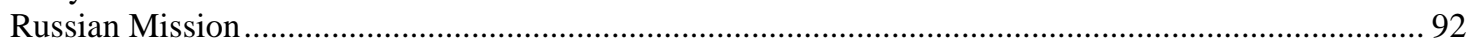

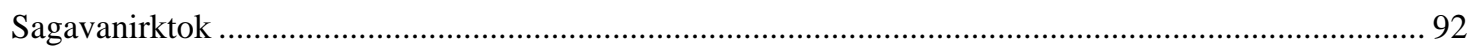

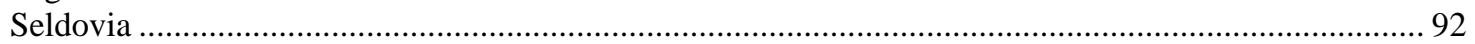

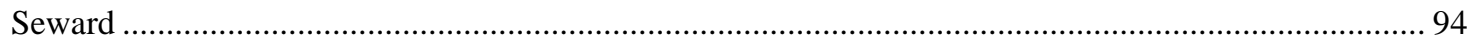

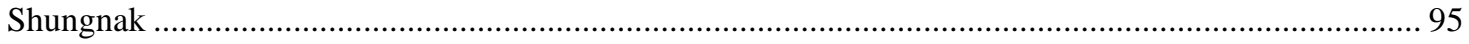

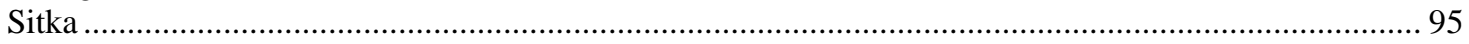

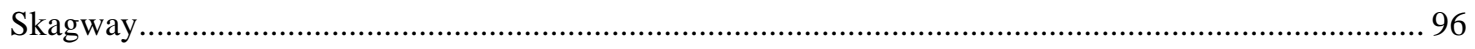

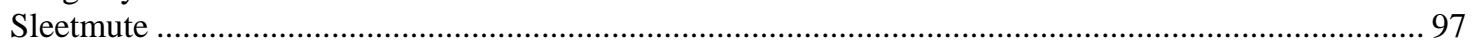

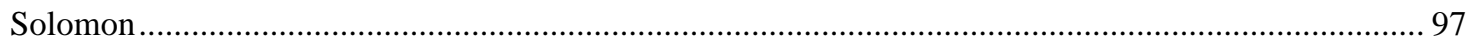

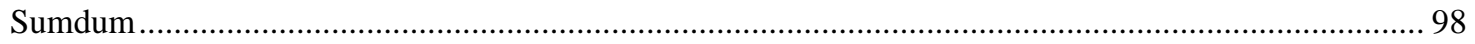

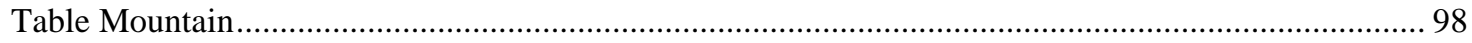

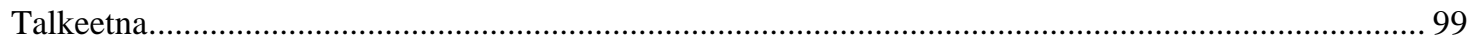

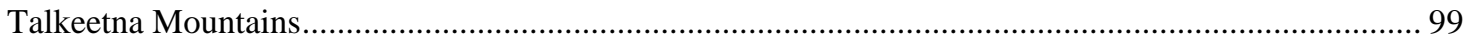

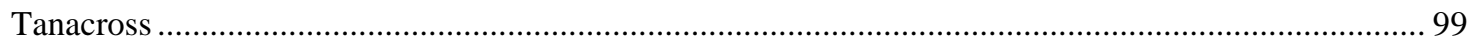

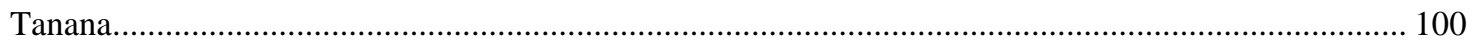

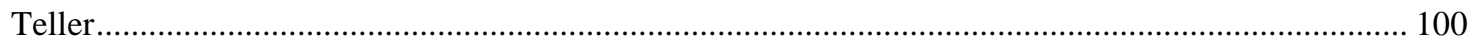

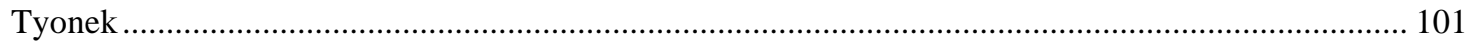

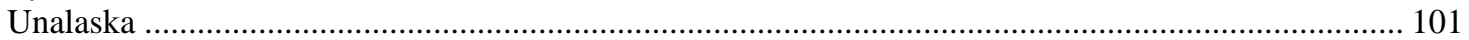

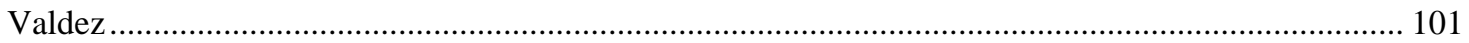

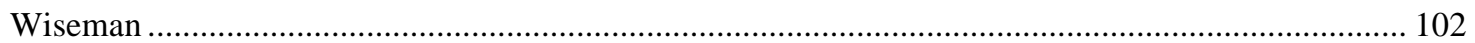

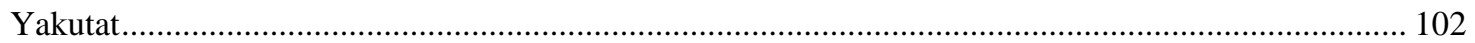




\title{
INTRODUCTION
}

This index was compiled to identify known industrial minerals occurrences in Alaska and to provide a bibliography of publications that address industrial minerals in at least moderate detail. Source materials include publications of the Alaska Division of Geological \& Geophysical Surveys, the U.S. Geological Survey, the U.S. Bureau of Mines, and many others. Publications listings and bibliographies were consulted to identify potentially relevant titles; the corresponding publications were examined and assessed for locations and descriptions of industrial minerals resources. This index should not be regarded as comprehensive, for there may be publications containing information on industrial minerals occurrences in Alaska that were not targeted by the search routines employed in the compilation of these maps.

Industrial minerals locations and commodities that were identified in selected publications are shown on sheets 1 and 2. Metallic industrial minerals are shown on sheet 1 and nonmetallic industrial minerals are shown on sheet 2. Construction materials (stone; sand and gravel) are not included in this bibliography because occurrences are so numerous and widespread that the documentation of their distribution is beyond the scope of this report. The first of the following bibliographic listings on which the maps were based is listed alphabetically by commodity. The second bibliographic listing is by 1:250,000scale U.S.G.S. quadrangle.

\section{METALLIC MINERALS}

\author{
Aluminum \\ Barker, J.C., Still, J.C., Mowatt, T.C., and Mulligan, J.J., 1981, Critical and Strategic Minerals in Alaska: \\ Cobalt, the Platinum-Group Metals, and Chromite; Bureau of Mines Information Circular 8869, \\ 8 p., 1 sheet, scale 1:250,000.
}

Berg, H.C, 1972, Geologic Map of Annette Island, Alaska; U.S. Geological Survey Miscellaneous Geologic Investigations Series Map I-684, 8 p., 1 sheet, scale 1:63,360.

Bird, M.L., 1977, Electron-Microprobe Analysis of Chromite and Olivine From Alpine Ultramafic Complexes; U.S. Geological Survey Open-File Report 77-236, 66 p.

Cobb, E.H., 1972, Metallic Mineral Resources Map of the Seldovia Quadrangle, Alaska; U.S. Geological Survey Miscellaneous Field Studies Map MF-397, 1 sheet, scale 1:250,000.

Cobb, E.H., 1972, Metallic Mineral Resources Map of the Sumdum Quadrangle, Alaska; U.S. Geological Survey Miscellaneous Field Studies Map MF-425, 1 sheet, 1:250,000.

Kaufman, A., 1958, Southeastern Alaska's Mineral Industry; Bureau of Mines Information Circular 7844, $37 \mathrm{p}$.

Rutledge, F.A., Thorne, R.L., Kerns, W.H., and Mulligan, J.J., 1953, Nonmetallic Deposits Accessible to the Alaska Railroad as Possible Sources of Raw Materials for the Construction Industry; Bureau of Mines Report of Investigations 4932, 129 p.

Sanford, R.S., and Cole, J.W., 1943, Claim Point Chromite Deposit, Kenai Peninsula, Alaska; Bureau of Mines War Minerals Report 253, 34 p. 
Sanford, R.S., and Cole, J.W., 1941, Investigation of the Claim Point Chromite Deposits, Kenai Peninsula, Alaska; Bureau of Mines Report of Investigations 4419, 11 p.

Thorne, R.L., and Wells, R.R., 1956, Studies of the Snettisham Magnetite Deposit, Southeastern Alaska; Bureau of Mines Report of Investigations 5195, 41 p.

U.S. Bureau of Mines, 1967, Potential Sources of Aluminum; Bureau of Mines Information Circular 8335, $148 \mathrm{p}$.

Warfield, R.S., 1962, Some Nonmetallic Mineral Resources for Alaska's Construction Industry; Bureau of Mines Report of Investigations 6002, 25 p.

\section{Chromium}

Alaska Department of Revenue, 1983, Mine License Application.

Alaska Department of Revenue, 1985, Mine License Application.

Bain, H.F., 1946, Alaska's Minerals as a Basis for Industry; Bureau of Mines Information Circular 7379, $89 \mathrm{p}$.

Barker, J.C., Still, J.C., Mowatt, T.C., and Mulligan, J.J., 1981, Critical and Strategic Minerals in Alaska: Cobalt, the Platinum-Group Metals, and Chromite; Bureau of Mines Information Circular 8869, 8 p., 1 sheet, scale 1:250,000.

Becker, G.F., 1898, Reconnaissance of Some Gold Fields of Southern Alaska with Some Notes on General Geology: in Wolcott, Charles D., dir.; U.S. Geological Survey 18th Annual Report, p. 7-86.

Berg, H.C., 1972, Geologic Map of Annette Island, Alaska; U.S. Geological Survey Miscellaneous Geologic Investigations Series Map I-684, 8 p., 1 sheet, scale 1:63,360.

Berg, H.C., 1999, Alaska Resource Data File-Prince Rupert Quadrangle; U.S. Geological Survey Open-File Report 99-306, 16 p.

Berg, H.C., and Cobb, E.H., 1967, Metalliferous Lode Deposits of Alaska; U.S. Geological Survey Bulletin $1246,254 \mathrm{p}$.

Berg, H.C., Elliott, R.L., and Koch, R.D., 1978, Map and Tables Describing Areas of Metalliferous Mineral Resource Potential in the Ketchikan and Prince Rupert Quadrangles, Alaska; U.S. Geological Survey Open-File Report 78-73M, 1 sheet, scale 1:250,000, 48 p. pamphlet.

Bird, M.L., 1977, Electron-Microprobe Analysis of Chromite and Olivine From Alpine Ultramafic Complexes; U.S. Geologic Survey Open-File Report 77-236, 66 p.

Bird, M.L., 1978, Electron-Microprobe Study of Chromatites Associated with Alpine Ultramafic Complexes and Some Genetic Implications; U.S. Geological Survey Open-File Report 78-119, 53 p.

Brooks, A.H., 1918, The Alaska Mining Industry in 1916, in Brooks, A.H., and others, Mineral Resources of Alaska, 1916; U.S. Geological Survey Bulletin 662, p. 11-62.

Brooks, A.H., 1921, The Future of Alaska Mining, in Martin G.C. and Others, Mineral Resources of Alaska, 1917; U.S. Geological Survey Bulletin 714, p. 5-57. 
Brooks, A.H., and others, 1915, Mineral Resources of Alaska: Report on Progress of Investigations in 1914; U.S. Geological Survey Bulletin 622, 391 p.

Brooks, A.H., and others, 1923, Mineral Resources of Alaska: Report on Progress of Investigations in 1921; U.S. Geological Survey Bulletin 739, 182 p.

Brosge, W.P., and Reiser, H.N., 1964, Geologic Map and Section of the Chandalar Quadrangle, Alaska; U.S. Geological Survey Miscellaneous Geologic Investigations Series Map I-375, 1 sheet, scale $1: 250,000$.

Bundtzen, T.K., Eakins, G.R., and Conwell, C. N., 1982 Review of Alaska's Mineral Resources; Alaska Division of Geological \& Geophysical Surveys and Alaska Department of Commerce and Economic Development AMR 81-82.

Burns, L.E., 1985, The Border Range Ultramafic and Mafic Complex, Southcentral Alaska: Cumulative Fractionates of Island-Arc Volcanics; Canadian Journal of Earth Science, v. 22; p. 1020-1038.

Campbell, L.J., 1995, Alaska's Mineral Industry Today; Alaska Geographic, v.22, no.3, p. 31-65.

Capps, S.R., 1937, Kodiak and Adjacent Islands, Alaska, in Smith, P.S. and Others, Mineral Resources of Alaska, 1934; U.S. Geological Survey Bulletin 880, p. 111-184, 1 sheet, scale 1:250,000.

Cass, J.T., 1959, Reconnaissance Geologic Map of the Candle Quadrangle, Alaska; U.S. Geological Survey Miscellaneous Geologic Investigations Series Map I-287, 1 sheet, scale 1:250,000.

Clark, A.L., and Cobb, E.H., 1972, Metallic Mineral Resources Map of the Talkeetna Quadrangle, Alaska; U.S. Geological Survey Miscellaneous Field Studies Map MF-369, 1 sheet, scale 1:250,000.

Clark, A.L., and Cobb, E.H., 1972, Metallic Mineral Resources Map of the Healy Quadrangle, Alaska; U.S. Geological Survey Miscellaneous Field Studies Map MF-394, 1 sheet, scale 1:250,000.

Clark, A.L., and Greenwood, W.R., 1972, Geochemistry and Distribution of Platinum-Group Metals in Mafic to Ultramafic Complexes of Southern and Southeastern Alaska, in Geological Survey Research; U.S. Geological Survey Professional Paper 800-C, p. C157-C160.

Cobb, E.H, 1973, Placer Deposits of Alaska; U.S. Geological Survey Bulletin 1374, 213 p., 1 sheet.

Cobb, E.H., 1972, Metallic Mineral Resources Map of the Anchorage Quadrangle, Alaska; U.S. Geological Survey Miscellaneous Field Studies Map MF-409, 1 sheet, scale 1:250,000.

Cobb, E.H., 1972, Metallic Mineral Resources Map of the Bering Glacier Quadrangle, Alaska; U.S. Geological Survey Miscellaneous Field Studies Map MF-373, 1 sheet, scale 1:250,000.

Cobb, E.H., 1972, Metallic Mineral Resources Map of the Big Delta Quadrangle, Alaska; U.S. Geological Survey Miscellaneous Field Studies Map MF-388, 1 sheet, scale 1:250,000.

Cobb, E.H., 1972, Metallic Mineral Resources Map of the Candle Quadrangle, Alaska; U.S. Geological Survey Miscellaneous Field Studies Map MF-389, 1 sheet, scale 1:250,000.

Cobb, E.H., 1972, Metallic Mineral Resources Map of the Chandalar Quadrangle, Alaska; U.S. Geological Survey Miscellaneous Field Studies Map MF-457, 1 sheet, scale 1:250,000.

Cobb, E.H., 1972, Metallic Mineral Resources Map of the Charley River Quadrangle, Alaska; U.S. Geological Survey Miscellaneous Field Studies Map MF-390, 1 sheet, scale 1:250,000. 
Cobb, E.H., 1972, Metallic Mineral Resources Map of the Eagle Quadrangle, Alaska; U.S. Geological Survey Miscellaneous Field Studies Map MF-393, 1 sheet, scale 1:250,000.

Cobb, E.H., 1972, Metallic Mineral Resources Map of the Hagemeister Island Quadrangle, Alaska; U.S. Geological Survey Miscellaneous Field Studies Map MF-362, 1 sheet, scale 1:250,000.

Cobb, E.H., 1972, Metallic Mineral Resources Map of the Icy Bay Quadrangle, Alaska; U.S. Geological Survey Miscellaneous Field Studies Map MF-411, 1 sheet, scale 1:250,000.

Cobb, E.H., 1972, Metallic Mineral Resources Map of the Iditarod Quadrangle, Alaska; U.S. Geological Survey Miscellaneous Field Studies Map MF-363, 1 sheet, scale 1:250,000.

Cobb, E.H., 1972, Metallic Mineral Resources Map of the Juneau Quadrangle, Alaska; U.S. Geological Survey Miscellaneous Field Studies Map MF-435, 1 sheet, scale 1:250,000.

Cobb, E.H., 1972, Metallic Mineral Resources Map of the Karluk Quadrangle, Alaska; U.S. Geological Survey Miscellaneous Field Studies Map MF-459, 1 sheet, scale 1:250,000.

Cobb, E.H., 1972, Metallic Mineral Resources Map of the Ketchikan Quadrangle, Alaska; U.S. Geological Survey Miscellaneous Field Studies Map MF-420, 1 sheet, scale 1:250,000.

Cobb, E.H., 1972, Metallic Mineral Resources Map of the Livengood Quadrangle, Alaska; U.S. Geological Survey Miscellaneous Field Studies Map MF-413, 1 sheet, scale 1:250,000.

Cobb, E.H., 1972, Metallic Mineral Resources Map of the Mount Fairweather Quadrangle, Alaska; U.S. Geological Survey Miscellaneous Field Studies Map MF-436, 1 sheet, scale 1:250,000.

Cobb, E.H., 1972, Metallic Mineral Resources Map of the Mount Hayes Quadrangle, Alaska; U.S. Geological Survey Miscellaneous Field Studies Map MF-414, 1 sheet, scale 1:250,000.

Cobb, E.H., 1972, Metallic Mineral Resources Map of the Ophir Quadrangle, Alaska; U.S. Geological Survey Miscellaneous Field Studies Map MF-367, 1 sheet, scale 1:250,000.

Cobb, E.H., 1972, Metallic Mineral Resources Map of the Petersburg Quadrangle, Alaska; U.S. Geological Survey Miscellaneous Field Studies Map MF-415, 1 sheet, scale 1:250,000.

Cobb, E.H., 1972, Metallic Mineral Resources Map of the Port Alexander Quadrangle, Alaska; U.S. Geological Survey Miscellaneous Field Studies Map MF-464, 1 sheet, scale 1:250,000.

Cobb, E.H., 1972, Metallic Mineral Resources Map of the Prince Rupert Quadrangle, Alaska; U.S. Geological Survey Miscellaneous Field Studies Map MF-437, 1 sheet, scale 1:250,000.

Cobb, E.H., 1972, Metallic Mineral Resources Map of the Seldovia Quadrangle, Alaska; U.S. Geological Survey Miscellaneous Field Studies Map MF-397, 1 sheet, scale 1:250,000.

Cobb, E.H., 1972, Metallic Mineral Resources Map of the Shungnak Quadrangle, Alaska; U.S. Geological Survey Miscellaneous Field Studies Map MF-448, 1 sheet, scale 1:250,000.

Cobb, E.H., 1972, Metallic Mineral Resources Map of the Sitka Quadrangle, Alaska; U.S. Geological Survey Miscellaneous Field Studies Map MF-467, 1 sheet, scale 1:250,000.

Cobb, E.H., 1972, Metallic Mineral Resources Map of the Tanana Quadrangle, Alaska; U.S. Geological Survey Miscellaneous Field Studies Map MF-371, 1 sheet, scale 1:250,000.

Cobb, E.H., 1972, Metallic Mineral Resources Map of the Yakutat Quadrangle, Alaska; U.S. Geological Survey Miscellaneous Field Studies Map MF-408, 1 sheet, scale 1:250,000. 
Cobb, E.H., 1973, Metallic Mineral Resources Map of the Craig Quadrangle, Alaska; U.S. Geological Survey Miscellaneous Field Studies Map MF-433, 1 sheet, scale 1:250,000.

Cobb, E.H., 1979, Summary of References to Mineral Occurrences (other than minerals fuels and construction materials) in the Seldovia Quadrangle, Alaska; U.S. Geological Survey Open-File Report 80-87, 47 p.

Cobb, E.H., 1979, Summary of References to Mineral Occurrences in the Afognak, Karluk, Kodiak, and Trinity Islands Quadrangles, Alaska; U.S. Geological Survey Open-File Report 79-860, 49 p.

Cobb, E.H., 1980, Summaries of Data on and Lists of References to Metallic and Selected Nonmetallic Mineral Deposits in the McCarthy Quadrangle, Alaska; U.S. Geological Survey Open-File Report $80-885,157 \mathrm{p}$.

Cobb, E.H., and Condon, W.H., 1972, Metallic Mineral Resources Map of the Goodnews Quadrangle, Alaska; U.S. Geological Survey Miscellaneous Field Studies Map MF-447, 1 sheet, scale $1: 250,000$.

Cobb, E.H., and Elliott, R.L., 1980, Summary of Data on and Lists of References to Metallic and Selected Nonmetallic Mineral Deposits in the Ketchikan and Prince Rupert Quadrangles, Alaska; U.S. Geological Survey Open-File Report 80-1053, 156 p.

Cobb, E.H., Mayfield, C.F., Brosge, W.P., 1981, Summaries of Data on and Lists of References to Metallic and Selected Non-Metallic Mineral Occurrences in Eleven Quadrangles in Northern Alaska-Summaries of Data to January 1, 1981; U.S. Geological Survey Open-File Report 81-767, 40 p.

Cobb, E.H., and Matson, Jr., 1972, Metallic Mineral Resources Map of the Valdez Quadrangle, Alaska; U.S. Geological Survey Miscellaneous Field Studies Map MF-438, 1 sheet, scale 1:250,000.

Dahlin, D.C., Kinney, J.J., and Brown, L.L., 1982, Alluvial Chromite Deposits, Red Mountain District, Kenai Peninsula, Alaska; Bureau of Mines.

Dahlin, D.C., Kinney, J.J., and Brown, L.L., 1985, Chromite Deposits Along the Border Ranges Fault, Southern Alaska. (In Two Parts.) 2. Mineralogy and Results of Beneficiatio; Bureau of Mines Information Circular 8991, $37 \mathrm{p}$.

Degenhart, C.E., Griffis, R.J., McOuat, J.F., and Bigelow, C.G., 1978, Mineral Studies of the Western Brooks Range Performed Under Contract to the U.S. Bureau of Mines, Contract \#J0155089, Vol. 1; Bureau of Mines Open-File Report 103-78, 544 p., 11 sheets, scale 1:63,360.

Dover, J., 1997, Alaska Resource Data File-Christian Quadrangle; U.S. Geological Survey Open-File Report 97-294, 6 p.

Dover, J.H., 1997, Alaska Resource Date File-Howard Pass Quadrangle; U.S. Geological Survey Open-File Report 97-29, 47 p.

Dover, J.H., 1997, Alaska Resource Date File-Misheguk Mountain Quadrangle; U.S. Geological Survey Open-File Report 97-297, 18 p.

Elliott, R.L., Berg, H.C., and Karl, S.M., 1978, Map and Table Describing Metalliferous and Selected Nonmetalliferous Mineral Deposits, Ketchikan and Prince Rupert Quadrangles, Alaska; U.S. Geological Survey Open-File Report 78-73-B, 17 p., 1 sheet, scale 1:250,000.

Enns, S., and Findley, A., 1977, Venetie Indian Reservation; Unpublished British Petroleum Mineral Survey $54 \mathrm{p}$. 
Fechner, S.A., 1988, Bureau of Mines Mineral Investigation of the Goodnews Bay Mining District, Alaska; Bureau of Mines Open-File Report 1-88, 230 p.

Foley, J.Y., 1992, Ophiolite and Other Ultramafic Metallogenic Provinces in Alaska (west of the 141th meridian); U.S. Geological Survey Open-File Report 92-20B, 65 p.

Foley, J.Y., and Barker, J.C., 1985, Chromite Deposits Along the Border Ranges Fault, Southern Alaska. (In Two Parts.) 1. Field Investigations and Descriptions of Chromite Deposits; Bureau of Mines Information Circular 8990, $58 \mathrm{p}$.

Foley, J.Y., Barker, J.C., and Brown, L.B., 1985, Critical and Strategic Minerals Investigations in Alaska: Chromium; U.S. Bureau of Mines Open File Report 97-85, 54 p.

Foley, J.Y., Barker, J.C., and Brown, L.L., 1986, Chromite Resources in Alaska; U.S. Bureau of Mines Information Circular 9087, p. 23-29.

Foley, J.Y., Burns, L.E., Schneider, C.L., and Forbes, R.B., 1989, Preliminary Report of Platinum Group Element Occurrences in Alaska; Alaska Department of Geological and Geophysical Surveys Public Data File 89-20, 33 p., scale 1:2,500,000.

Foley, J.Y., and McDermott, M. M., 1983, Podiform Chromite Occurrences in the Caribou Mountain and Lower Kanuti River Areas, Central Alaska. Part I: Reconnaissance Investigations; Bureau of Mines Information Circular 8915, 27 p.

Foley, J.Y., Hinderman, T., Kirby, D.E., and Mardock, C.L., 1983, Chromite Occurrences in the Kaiyuh Hills, West-Central Alaska; Bureau of Mines Open-File Report 178-84, 20 p.

Forbes, R.B., 1974, Garnet-Clinopyrozenite From Red Mountain Pluton, Alaska; Geological Society of America Bulletin v. 85, p. 285-292.

Foster, R.L., and Chapman, R.M., 1967, Locations and Descriptions of Lode Prospects in the Livengood Area, East-Central Alaska; U.S. Geological Survey Open-File Report 67-91, 6 p.

Gill, A.C., 1922, Chromite of Kenai Peninsula, Alaska; U.S. Geological Survey Bulletin 742, 52 p.

Gill, A.C., 1920, Preliminary Report on the Chromite of Kenai Peninsula; U.S. Geological Survey Bulletin 712 , p. 99-129.

Glover, A.E., 1954, Kelp and Duke Islands Magnetics; Alaska Territorial Department of Mines Mineral Investigations MI-122-2, $1 \mathrm{p}$.

Gonnason Exploration Co., 1963, Magnetometer Survey Jumbo Mine (Prince of Wales Island); Alaska Territorial Department of Mines Miscellaneous Report MR-119-4, 5 p., 2 maps.

Grant, U.S., and Higgins, D.F., 1910, Preliminary Report on the Mineral Resources of the Southern Part of Kenai Peninsula; U.S. Geological Survey Bulletin 442, p. 166-178.

Gray, J.E., Sanzolone, R.F., 1996, Environmental Studies of Mineral Deposits in Alaska; U.S. Geological Survey Bulletin 2156, $39 \mathrm{p}$.

Griscom, A., 1978, Aeromagnetic Map and Interpretation of the Goodnews and Hagemeister Island Quadrangles Region, Southwestern Alaska; U.S. Geological Survey Open-File Report 78-9-C, 22 p., 2 sheets, scale 1:250,000. 
Grybeck, D.J., 1977, Map Showing Known Mineral Deposits of the Brooks Range, Alaska; U.S. Geological Survey Open-File Report 77-166-C, 45 p., 1 sheet, scale 1:1,000,000.

Guild, P.W., 1942, Chromite Deposits of Kenai Peninsula, Alaska; U.S. Geological Survey Bulletin 931-G, p. 139-175.

Hargreaves, D., 1975, The Livengood Placer Deposit--A Developing Alaskan Gold Mine; Mining Magazine 7505, 4 p.

Hawley, C.C., and Garcia, G., 1976, Mineral Appraisal and Geologic Background of the Venetie Native Lands; Unpublished Bureau of Indian Affairs Contract Report No. 6E00-0102598.

Heide, H.E., Wright, W.S., and Rutledge, F.A., 1949, Investigation of the Kobuk River Asbestos Deposits, Kobuk District, Northwestern Alaska; Bureau of Mines Report of Investigations 4414, 25 p.

Hoare, J.M., and Coonrad, W.L., 1961, Geologic Map of the Hagemeister Island Quadrangle, Alaska; U.S. Geological Survey Miscellaneous Geologic Investigations Series Map I-321, 1 sheet, scale $1: 250,000$.

Holdsworth, P.R., 1954, Investigation of Claim Staking (Union Bay Area); Alaska Territorial Department of Mines Prospect Evaluation PE-119-23.

Holt, S.P., Wright, W.S., and Fosse, E.L., 1945, Jumbo Basin, Prince of Wales Island, Southeastern Alaska--Iron, Copper; Bureau of Mines War Minerals Report 447, 13 p.

Huber, Jeff, 1999, Alaska Resource Data File-Seldovia Quadrangle; U.S. Geological Survey Open-File Report 99-391, $70 \mathrm{p}$.

Hudson, T.L., Miller, M.L., and Peckthorn, W.J., 1977, Map Showing Metalliferous and Selected Nonmetalliferous Mineral Deposits, Seward Peninsula, Alaska; U.S. Geological Survey Open-File Report 77-796-B, 46 p., 1 sheet, scale 1:1,000,000.

Irvine, T.N., 1959, The Ultramafic Complex and Related Rocks of Duke Island, Southeastern Alaska; California Inst. Technology, Pasadena, Ph.D. thesis, 320 p.

Irvine, T.N., 1974, Petrology of the Duke Island Ultramafic Complex, Southeastern Alaska; Geological Society of America Memoir 138, 240 p.

Karl, S.M., Berg, H.C., Grybeck, D.J., and Abramson, B.S., 1980, Preliminary Map and Tables Describing Metalliferous and Selected Nonmetalliferous Mineral Deposits in the Petersburg \& Eastern Port Alexander Quadrangles, Alaska; U.S. Geological Survey Open-File Report 80-793, 14 p., 1 sheet, scale 1:250,000.

Lathram, E.H., Loney, R.A., Condon, W.H., and Berg, H.C., 1959, Progress Map of the Geology of the Juneau Quadrangle, Alaska; U.S. Geological Survey Miscellaneous Geologic Investigations Series Map I-303, 1 sheet, scale 1:250,000.

Loney, R.A., Berg, H.C., Pomeroy, J.S., and Brew, D.A., 1963, Reconnaissance Geologic Map of Chichagof Island and Northwestern Baranof Island, Alaska; U.S. Geological Survey Miscellaneous Geologic Investigations Series Map I-388, 7 p., 1 sheet, scale 1:250,000.

MacKevett, B.N., Jr., Singer, D.A., and Holloway, C.D., 1978, Maps and Tables Describe Metalliferous Mineral Resource Potential of Southern Alaska; U.S. Geological Survey Open-File Report 78-1-E, p., maps, scale 1:1,000,000.

MacKevett, E.M., Jr., 1976, Mineral Deposits and Occurrences in the McCarthy Quadrangle, Alaska; U.S. Geological Survey Miscellaneous Field Studies Map MF-773-B, 1 sheet, scale 1:250,000. 
MacKevett, E.M., Jr., and Holloway, C.D., 1977, Map Summarizing Metalliferous and Selected Nonmetalliferous Mineral Deposits in the Eastern Part of Southern Alaska; U.S. Geological Survey Open-File Report 77-169-A, 99 p., 1 sheet, scale 1:1,000,000.

MacKevett, E.M., Jr., and Holloway, C.D., 1977, Map Showing Metalliferous Mineral Deposits in the Western Part of Southern Alaska; U.S. Geological Survey Open-File Report 77-169-F, 39 p., 1 sheet, scale 1:1,000,000.

Maddren, A.G., 1919, The Beach Placers of the West Coast of Kodiak Island, Alaska, in Martin, G.C., and Others, Mineral Resources of Alaska, 1917; U.S. Geological Survey Bulletin 692, p. 299-319.

Maloney, R.P., 1962, Investigation of Mercury-Antimony Deposits Near Flat, Yukon River Region, Alaska; Bureau of Mines Report of Investigations 5991, 44 p.

Martin, G.C., 1913, Mineral Deposits of Kodiak and Neighboring Islands, in Brooks, A.H., and Others, Mineral Resources of Alaska, 1912; U.S. Geological Survey Bulletin 542, p. 125-136.

Martin, G.C., 1920, The Alaskan Mining Industry in 1918; U.S. Geological Survey Bulletin 712, p. 11-52.

Martin, G.C., and others, 1915, Geology and Mineral Resources of Kenai Peninsula, Alaska; U.S. Geological Survey Bulletin 587, 243 p.

Mattson, M.J., 1978, Production Statistics of Cache Creek, Yentna District, Talkeetna Quadrangle; Letter to Thad E. Sandford.

McGee, D.L., 1972, Kodiak Island and Vicinity, Alaska, Geology and Mineral Resources; Alaska Division of Geological and Geophysical Surveys Open-File Report 31, 7 p., 1 sheet, scale 1:250,000.

Mertie, J.B., 1969, Economic Geology of the Platinum Minerals; U.S. Geological Survey Professional Paper 630, $120 \mathrm{p}$.

Mertie, J.B., Jr., 1919, Chromite Deposits in Alaska; U.S. Geological Survey Bulletin 692, p. 265-267.

Mining World, 1951, Alaska--Gold Output at Post-War Peak: Platinum and Tin Placering; Mining World 5104.

Moxham, R.M., and Nelson, A.E., 1952, Reconnaissance for Radioactive Deposits in the Southern Cook Inlet Region, Alaska, 1949; U.S. Geological Survey Circular 207, 7 p.

Mulligan, J.J., 1959, Sampling Stream Gravels for Tin, Near York, Seward Peninsula, Alaska; Bureau of Mines Report of Investigations 5520, 25 p.

Noel, G.A., 1963, Peacock Fraction; Alaska Division of Geological \& Geophysical Surveys Miscellaneous Report MR-119-5, 6 p.

Payne, T.G., Dana, S., Fischer, W., Gryc, G., Lathram, E., Morris, R., Tappan, H., and Yuster, S., 1952, Geology of the Arctic Slope of Alaska; U.S. Geological Survey Oil and Gas Investigations Map 126, 1 sheet, scale 1:1,000,000.

Pilcher, S.H., 1999, Alaska Resource Data File-Karluk Quadrangle; U.S. Geological Survey Open-File Report 99-42, $71 \mathrm{p}$.

Reed, B.L., Nelson, S.W., Curtin, G.C., and Singer, D.A., 1978, Mineral Resources Map of the Talkeetna Quadrangle, Alaska; U.S. Geological Survey Miscellaneous Field Studies Map MF-870-D, 1 sheet, scale 1:250,000. 
Richter, D.H., 1997, Alaska Resource Data File-Nabesna Quadrangle; U.S. Geological Survey Open-File Report 97-749, 93 p.

Richter, D.H., Singer, D.A., and Cox, D.P., 1975, Mineral Resources Map of the Nabesna Quadrangle, Alaska; U.S. Geological Survey Miscellaneous Field Studies Map MF-655-K, 1 sheet, scale $1: 250,000$.

Roberts, W.S., 1984, Economic Potential for Chromium, Platinum, and Palladium in the Mount Hurst Ultramafics, West-Central Area, Alaska; Bureau of Mines Open-File Report 22-84, 52 p.

Ruckmick, J.C., and Noble, J.A., 1959, Origin of the Ultramafic Complex at Union Bay, Southeastern Alaska; Geological Society of America Bulletin 5908, 36 p.

Rutledge, F.A., 1946, Exploration of Red Mountain Chromite Deposits, Kenai Peninsula, Alaska; Bureau of Mines Report of Investigations 3885, 26 p.

Sanford, R.S., 1944, Red Mountain Chromite Deposits, Kenai Peninsula, Alaska; Bureau of Mines War Minerals Report 191, 51 p.

Sanford, R.S., and Cole, J.W., 1941, Investigation of the Claim Point Chromite Deposits, Kenai Peninsula, Alaska; Bureau of Mines Report of Investigations 4419, 11 p.

Sanford, R.S., and Cole, J.W., 1943, Claim Point Chromite Deposit, Kenai Peninsula, Alaska; Bureau of Mines War Minerals Report 253, 34 p.

Sanford, R.S., and Cole, J.W., 1949, Investigation of Claim Point Chromite Deposits, Kenai Peninsula, Alaska; U.S. Bureau of Mines Report of Investigations 4419, 11 p.

Saunders, R. H., 1958, Notes on Mineral Resources of the Livengood Creek, Hess Creek, and Tributaries; Alaska Territorial Department of Mines Miscellaneous Report MR-49-3, 5 p.

Saunders, R.H., 1955, Sours Chromium Prospect (Agashashok R.); Alaska Territorial Department of Mines Prospect Evaluation PE-26-1, 4 p.

Saunders, R.H., 1956, Flume Creek, Lode Gold Prospect (Alaska Nickel Co.); Alaska Territorial Department of Mines Prospect Evaluation PE-60-4, 10 p.

Smith, P.S., 1933, Mineral Industry of Alaska in 1931; U.S. Geological Survey Bulletin 844-A, p. 1-82.

Smith, P.S., 1934, Mineral Industry of Alaska in 1932; U.S. Geological Survey Bulletin 857-A, p. 1-91.

Smith, P.S., 1936, Mineral Industry of Alaska in 1934; U.S. Geological Survey Bulletin 868-A, p. 1-91.

Smith, P.S., 1937, Mineral Industry of Alaska in 1935; U.S. Geological Survey Bulletin 880-A, p. 1-95.

Smith, P.S., 1938, Mineral Industry of Alaska in 1936; U.S. Geological Survey Bulletin 897-A, p. 1-107

Smith, P.S., 1941, The Mineral Industry in 1939, in Smith, P.S., and Others, Mineral Resources of Alaska, 1940; U.S. Geological Survey Bulletin 926, p.1-106.

Smith, P.S., 1933, The Mineral Industry of Alaska in 1930, in Smith, P.S., and Others, Mineral Resources of Alaska, 1930; U.S. Geological Survey Bulletin 836, p. 1-83.

Smith, P.S., 1942, The Mineral Industry of Alaska in 1940, in Smith, P.S., and Others, Mineral Resources of Alaska, 1940; U.S. Geological Survey Bulletin 933, p. 1-10. 
Southworth, D.D., and Foley, J.Y., 1986, Lode Platinum-Group Metals Potential of the Goodnews Bay Ultramafic Complex, Alaska; Bureau of Mines Open-File Report 51-86, 82 p., 2 sheets, scale $1: 63,360$.

Taylor, C.D., Meier, A.L., and d'Angelo, W.M., 1998, A Reconnaissance Study of the Chemistry of Natural Waters Draining Chromite-Bearing Ultramafic Complexes in Alaska; U.S. Geological Survey Professional Paper 1595, p. 9-16.

Thorne, R.L., and Wright, W.S., 1948, Sampling Methods and Results at the Sullivan Creek Tin Placer Deposits, Manley Hot Springs, Tofty, Alaska; Bureau of Mines Report of Investigations 4346, 8 p.

Toth, M.I., 1981, Petrology, Geochemistry, and Origin of the Red Mountain Ultramafic Body Near Seldovia, Alaska; U.S. Gelogical Survey Open-File Report 81-0514, 92 p.

Twenhofel, W.S., 1953, Potential Alaska Mineral Resources for Proposed Electrochemical and Electrochemical and Eletrometallurgical Industries in the Upper Lynn Canal Area, Alaska; U.S. Geological Survey Circular 252, 14 p.

Tysdal, R.G., 1979, Mines, Prospects, and Occurrences Map of the Seward and Blying Sound Quadrangles, Alaska; U.S. Geological Survey Miscellaneous Field Studies Map MF-880-A, 2 sheets, scale $1: 250,000$.

U.S. Bureau of Mines, 1974, Claim Map, Prince Rupert; U.S. Bureau of Mines Map, no. 122, Scale $1: 250,000$.

U.S. Bureau of Mines, 1985, Unpublished data, 1970-1985.

U.S. Bureau of Mines, 1995, Spatial Data Extracted from the Minerals Availability System/ Mineral Industry Location System (MAS/MILS); U.S. Bureau of Mines Special Publication 12-95, CDROM.

Wells, R.R., Sterling, F.T., Erspamer, E.G., and Stickney, W.A., 1957, Laboratory Concentration of Chromite Ores, Red Mountain District, Kenai Peninsula, Alaska; Bureau of Mines Report of Investigations $5377,22 \mathrm{p}$.

Williams, J.A., 1954, Magnetic Exploration of the Red Mountain Chromite Deposit, Kenai, Peninsula; Prospect or Properties Examined, Alaska Territorial Department of Mines PE 104-3, 22 p.

Wright, W.S., and Fosse, E.L., 1946, Exploration of the Jumbo Basin Iron Deposit, Prince of Wales Island, Southeastern Alaska; Bureau of Mines Report of Investigations 3952, 9 p.

\section{Columbium}

Cobb, E.H., 1972, Metallic Mineral Resources Map of the Bethel Quadrangle, Alaska; U.S. Geological Survey Miscellaneous Field Studies Map MF-455, 1 sheet, scale 1:250,000.

Cobb, E.H., 1972, Metallic Mineral Resources Map of the Coleen Quadrangle, Alaska, U.S. Geological Survey Miscellaneous Field Studies Map MF-403, 1 sheet, scale 1:250,000.

Cobb, E.H., 1972, Metallic Mineral Resources Map of the Fairbanks Quadrangle, Alaska; U.S. Geological Survey Miscellaneous Field Studies Map MF-410, 1 sheet, scale 1:250,000.

Cobb, E.H., 1972, Metallic Mineral Resources Map of the Juneau Quadrangle, Alaska; U.S. Geological Survey Miscellaneous Field Studies Map MF-435, 1 sheet, scale 1:250,000. 
Cobb, E.H., 1972, Metallic Mineral Resources Map of the Solomon Quadrangle, Alaska; U.S. Geological Survey Miscellaneous Field Studies Map MF-445, 1 sheet, scale 1:250,000.

Cobb, E.H., 1972, Metallic Mineral Resources Map of the Tanana Quadrangle, Alaska; U.S. Geological Survey Miscellaneous Field Studies Map MF-371, 1 sheet, scale 1:250,000.

Cobb, E.H., 1973, Placer Deposits of Alaska; U.S. Geological Survey Bulletin 1374, 213 p., 1 sheet.

Cobb, E.H., 1978, Summary of References to Mineral Occurrences (Other Than Mineral Fuels and Construction Materials) in the Solomon Quadrangle, Alaska; U.S. Geological Survey Open-File Report 78-181, $185 \mathrm{p}$.

Eberlein, G.D., Chapmen, R.M., Foster, H.L., and Gassaway, J.S., 1977, Map and Table Describing Known Metalliferous and Selected Nonmetalliferous Mineral Deposits in Central Alaska; U.S. Geological Survey Open-File Report 77-168-D, 131 p., 1 sheet, scale 1:1,000,000.

Lathram, E.H., Loney, R.A., Condon, W.H., and Berg, H.C., 1959, Progress Map of the Geology of the Juneau Quadrangle, Alaska; U.S. Geological Survey Miscellaneous Geologic Investigations Series Map I-303, 1 sheet, scale 1:250,000.

Thomas, B.I., 1957, Tin-Bearing Placer Deposits Near Tofty, Hot Springs District, Central Alaska; Bureau of Mines Report of Investigations 5373, 56 p.

Thorne, R.L., and Wright, W.S., 1945, Sullivan Creek Tailings, Manley Hot Springs, Tofty, Alaska-Tin; Bureau of Mines War Minerals Report 467, 9 p.

Warner, J.D., 1989, Columbium-, Rare-Earth-Element-, and Thorium-Bearing Veins Near Salmon Bay, Southeastern Alaska; U.S. Bureau of Mines Open-File Report 06-89, 25 p.

Wayland, R.G., 1961, Tofty Tin Belt, Manley Hot Springs District, Alaska; U.S. Geological Survey Bulletin 1058-I, 51 p., 2 sheets, scales 1:96,000 and 1:24,000.

Williams, J.A., 1955, Carol Anne Property (Kendrick Bay); Alaska Territorial Department of Mines Prospect Evaluation PE-121-7, 5 p.

Williams, J.A., 1955, I \& L Property (Kendrick Bay), Alaska Territorial Department of Mines Prospect Evaluation PE-121-5, 8 p.

\section{Iron}

Alaska Division of Geological \& Geophysical Surveys, 1961, Paul Pieper Claims, North Bradfield River; Alaska Territorial Department of Mines Miscellaneous Report MR-118-3.

American Exploration \& Mining Co. and Walper, 1966, Muir Inlet Nunatak Drill Logs; Alaska Division of Geological \& Geophysical Surveys Miscellaneous Report MR-111-2, 42 p., 1 map.

Apell, G.A., Erickson, A.E., and Tolonen, A.W., 1943, Muir Inlet or Nunatak Molybdenum Deposits, Glacier Bay, Southeastern Alaska; Bureau of Mines War Minerals Report 300, 4 p.

Asbury, D.W., 1964, Vevelstad Copper-Iron Property, Stag Bay; Alaska Division of Geological \& Geophysical Surveys Miscellaneous Report MR-114-10, 3 p.

Bain, H.F., 1946, Alaska's Minerals as a Basis for Industry; Bureau of Mines Information Circular 7379, $89 \mathrm{p}$. 
Barker, J.C., Still, J.C., Mowatt, T.C., and Mulligan, J.J., 1981, Critical and Strategic Minerals in Alaska: Cobalt, the Platinum-Group Metals, and Chromite; Bureau of Mines Information Circular 8869, 8 p., 1 sheet, scale 1:250,000.

Bassett, C.D., 1952, Alaska Iron Ores and Their Available Markets; Alaska Territorial Department of Mines Miscellaneous Report MR-191-6, 5 p.

Berg, H.C., 1999, Alaska Resource Data File-Prince Rupert Quadrangle; U.S. Geological Survey Open-File Report 99-306, 16p.

Berg, H.C., and Cobb, E.H., 1967, Metalliferous Lode Deposits of Alaska; U.S. Geological Survey Bulletin $1246,254 \mathrm{p}$.

Berg, H.C., Decker, J.E., and Abramson, B.S., 1981, Metallic Mineral Deposits of Southeastern Alaska; U.S. Geological Survey Open-File Report 81-122, 145 p., 1 sheet, scale 1:1,000,000.

Berg, H.C., Elliott, R.L., and Koch, R.D., 1988, Geologic Map of the Ketchikan and Prince Rupert Quadrangles, Southeastern Alaska; U.S. Geological Survey Miscellaneous Investigations Series Map I-1807, 1 sheet, scale 1:250,000.

Bird, M.L., 1977, Electron-Microprobe Analysis of Chromite and Olivine From Alpine Ultramafic Complexes; U.S. Geological Survey Open-File Report 77-236, 66 p.

Brew, D.A., Grybeck, D.J., Johnson, B.R., and Jachens R.C., 1977, Mineral Resources of the Tracy ArmFords Terror Wilderness Study Area and Vicinity, Alaska; U.S. Geological Survey Open-File Report 77-649, 467 p., 4 sheets, scale 1:125,000.

Brew, D.A., Johnson, B.R., Grybeck, D.J., Griscom, A., and Barnes, D.F., 1978, Mineral Resources of the Glacier Bay National Wilderness Study Area, Alaska; U.S. Geological Survey Open-File Report 78-494, 670 p., 6 sheets, 1:250,000.

Brooks, A.H., 1918, The Alaska Mining Industry in 1916, in Brooks, A.H., and others, Mineral Resources of Alaska, 1916; U.S. Geological Survey Bulletin 662, p. 11-62.

Brooks, A.H., 1921, The Future of Alaska Mining, in Martin G.C. and Others, Mineral Resources of Alaska, 1917; U.S. Geological Survey Bulletin 714, p. 5-57.

Burns, L.E., 1985, The Border Range Ultramafic and Mafic Complex, Southcentral Alaska: Cumulative Fractionates of Island-Arc Volcanics; Canadian Journal of Earth Science, v. 22, p. 1020-1038.

Bundtzen, T.K., Eakins, G.R., and Conwell, C.N., 1982, Review of Alaska's Mineral Resources; Alaska Division of Geological \& Geophysical Surveys and Alaska Department of Commerce and Economic Development, AMR 81-82.

Clark, A.L., and Cobb, E.H., 1972, Metallic Mineral Resources Map of the Talkeetna Quadrangle, Alaska; U.S. Geological Survey Miscellaneous Field Studies Map MF-369, 1 sheet, scale 1:250,000.

Clark, A.L., and Cobb, E.H., 1972, Metallic Mineral Resources Map of the Healy Quadrangle, Alaska; U.S. Geological Survey Miscellaneous Field Studies Map MF-394, 1 sheet, scale 1:250,000.

Cobb, E.H., 1972, Metallic Mineral Resources Map of the Ambler River Quadrangle, Alaska; U.S. Geological Survey Miscellaneous Field Studies Map MF-454, 1 sheet, scale 1:250,000. 
Cobb, E.H., 1972, Metallic Mineral Resources Map of the Bering Glacier Quadrangle, Alaska; U.S. Geological Survey Miscellaneous Field Studies Map MF-373, 1 sheet, scale 1:250,000.

Cobb, E.H., 1972, Metallic Mineral Resources Map of the Bethel Quadrangle, Alaska; U.S. Geological Survey Miscellaneous Field Studies Map MF-455, 1 sheet, scale 1:250,000.

Cobb, E.H., 1972, Metallic Mineral Resources Map of the Charley River Quadrangle, Alaska; U.S. Geological Survey Miscellaneous Field Studies Map MF-390, 1 sheet, scale 1:250,000.

Cobb, E.H., 1972, Metallic Mineral Resources Map of the Cold Bay Quadrangle, Alaska; U.S. Geological Survey Miscellaneous Field Studies Map MF-441, 1 sheet, scale 1:250,000.

Cobb, E.H., 1972, Metallic Mineral Resources Map of the Dillingham Quadrangle, Alaska; U.S. Geological Survey Miscellaneous Field Studies Map MF-375, 1 sheet, scale 1:250,000.

Cobb, E.H., 1972, Metallic Mineral Resources Map of the Dixon Entrance Quadrangle, Alaska; U.S. Geological Survey Miscellaneous Field Studies Map MF-434, 1 sheet, scale 1:250,000.

Cobb, E.H., 1972, Metallic Mineral Resources Map of the Hagemeister Island Quadrangle, Alaska; U.S. Geological Survey Miscellaneous Field Studies Map MF-362, 1 sheet, scale 1:250,000.

Cobb, E.H., 1972, Metallic Mineral Resources Map of the Karluk Quadrangle, Alaska; U.S. Geological Survey Miscellaneous Field Studies Map MF-459, 1 sheet, scale 1:250,000.

Cobb, E.H., 1972, Metallic Mineral Resources Map of the Kenai Quadrangle, Alaska; U.S. Geological Survey Miscellaneous Field Studies Map MF-377, 1 sheet, scale 1:250,000.

Cobb, E.H., 1972, Metallic Mineral Resources Map of the Livengood Quadrangle, Alaska; U.S. Geological Survey Miscellaneous Field Studies Map MF-413, 1 sheet, scale 1:250,000.

Cobb, E.H., 1972, Metallic Mineral Resources Map of the Mount Fairweather Quadrangle, Alaska; U.S. Geological Survey Miscellaneous Field Studies Map MF-436, 1 sheet, scale 1:250,000.

Cobb, E.H., 1972, Metallic Mineral Resources Map of the Mount Hayes Quadrangle, Alaska; U.S. Geological Survey Miscellaneous Field Studies Map MF-414, 1 sheet, scale 1:250,000.

Cobb, E.H., 1972, Metallic Mineral Resources Map of the Mount McKinley Quadrangle, Alaska; U.S. Geological Survey Miscellaneous Field Studies Map MF-366, 1 sheet, scale 1:250,000.

Cobb, E.H., 1972, Metallic Mineral Resources Map of the Nome Quadrangle, Alaska; U.S. Geological Survey Miscellaneous Field Studies Map MF-463, 1 sheet, scale 1:250,000.

Cobb, E.H., 1972, Metallic Mineral Resources Map of the Petersburg Quadrangle, Alaska; U.S. Geological Survey Miscellaneous Field Studies Map MF-415, 1 sheet, scale 1:250,000.

Cobb, E.H., 1972, Metallic Mineral Resources Map of the Port Alexander Quadrangle, Alaska; U.S. Geological Survey Miscellaneous Field Studies Map MF-464, 1 sheet, scale 1:250,000.

Cobb, E.H., 1972, Metallic Mineral Resources Map of the Port Moller Quadrangle, Alaska; U.S. Geological Survey Miscellaneous Field Studies Map MF-443, 1 sheet, scale 1:250,000.

Cobb, E.H., 1972, Metallic Mineral Resources Map of the Prince Rupert Quadrangle, Alaska; U.S. Geological Survey Miscellaneous Field Studies Map MF-437, 1 sheet, scale 1:250,000.

Cobb, E.H., 1972, Metallic Mineral Resources Map of the Seldovia Quadrangle, Alaska; U.S. Geological Survey Miscellaneous Field Studies Map MF-397, 1 sheet, scale 1:250,000. 
Cobb, E.H., 1972, Metallic Mineral Resources Map of the Sitka Quadrangle, Alaska; U.S. Geological Survey Miscellaneous Field Studies Map MF-467, 1 sheet, scale 1:250,000.

Cobb, E.H., 1972, Metallic Mineral Resources Map of the Sumdum Quadrangle, Alaska; U.S. Geological Survey Miscellaneous Field Studies Map MF-425, 1 sheet, scale 1:250,000.

Cobb, E.H., 1972, Metallic Mineral Resources Map of the Taku River Quadrangle, Alaska; U.S. Geological Survey Miscellaneous Field Studies Map MF-407, 1 sheet, scale 1:250,000.

Cobb, E.H., 1972, Metallic Mineral Resources Map of the Yakutat Quadrangle, Alaska; U.S. Geological Survey Miscellaneous Field Studies Map MF-408, 1 sheet, scale 1:250,000.

Cobb, E.H., 1972, Placer Deposits of Alaska; U.S. Geological Survey Open-File Report 72-71.

Cobb, E.H., 1972,Metallic Mineral Resources Map of the Skagway Quadrangle, Alaska; U.S. Geological Survey Miscellaneous Field Studies Map MF-424, 1 sheet, scale 1:250,000.

Cobb, E.H., 1973, Metallic Mineral Resources Map of the Craig Quadrangle, Alaska; U.S. Geological Survey Miscellaneous Field Studies Map MF-433, 1 sheet, scale 1:250,000.

Cobb, E.H., 1973, Placer Deposits of Alaska; U.S. Geological Survey Bulletin 1374, 213 p., 1 sheet.

Cobb, E.H., 1975, Summary of References to Mineral Occurrences (Other Than Mineral Fuels and Construction Materials) in the Bendeleben Quadrangle, Alaska; U.S. Geological Survey Open-File Report 75-429, 123 p.

Cobb, E.H., 1979, Summary of References to Mineral Occurrences (other than minerals fuels and construction materials) in the Seldovia Quadrangle, Alaska; U.S. Geological Survey Open-File Report 80-87, 47 p.

Cobb, E.H., and Condon, W.H., 1972, Metallic Mineral Resources Map of the Goodnews Quadrangle, Alaska; U.S. Geological Survey Miscellaneous Field Studies Map MF-447, 1 sheet, scale $1: 250,000$.

Cobb, E.H., and Elliott, R.L., 1980, Summary of Data on and Lists of References to Metallic and Selected Nonmetallic Mineral Deposits in the Ketchikan and Prince Rupert Quadrangles, Alaska; U.S. Geological Survey Open-File Report 80-1053, 156 p.

Cobb, E.H., and Matson, N. A., Jr., 1972, Metallic Mineral Resources Map of the Valdez Quadrangle, Alaska; U.S. Geological Survey Miscellaneous Field Studies Map MF-438, 1 sheet, scale $1: 250,000$.

Condon, W.H., and Cass, J.T., 1958, Map of a Part of the Prince William Sound Area, Alaska; Showing Linear Geologic Features as Shown on Aerial Photographs; U.S. Geological Survey Miscellaneous Geologic Investigations Series Map I-273, 1 sheet, scale 1:125,000.

Detterman, R.L., and Reed, B.L., 1964, Preliminary Map of the Geology of the Iliamna Quadrangle, Alaska; U.S. Geological Survey Miscellaneous Geologic Investigations Series Map I-407, 1 sheet, scale $1: 250,000$.

Detterman, R.L., and Reed, B.L., 1972, Metallic Mineral Resources Map of the Iliamna Quadrangle, Alaska; U.S. Geological Survey Miscellaneous Field Studies Map MF-364, 1 sheet, scale $1: 250,000$. 
Eakins, G.R., 1975, Uranium Investigations in Southeastern Alaska; Alaska Division of Geological \& Geophysical Surveys Geologic Report 44, 62 p.

Eberlein, G.D., Chapman, R.M., Foster, H.L., and Gassaway, J.S., 1977, Map and Table Describing Known Metalliferous and Selected Nonmetalliferous Mineral Deposits in Central Alaska; U.S. Geological Survey Open-File Report 77-168-D, 131 p., 1 sheet, scale 1:1,000,000.

Elliott, R.L., Berg, H.C., and Karl, S.M., 1978, Map and Table Describing Metalliferous and Selected Nonmetalliferous Mineral Deposits, Ketchikan and Prince Rupert Quadrangles, Alaska; U.S. Geological Survey Open-File Report 78-73-B, 17 p., 1 sheet, scale 1:250,000.

Erickson, A.W., 1948, Investigation of the Tolstoi Mountain Iron Deposits, Kasaan Peninsula, Prince of Wales Island, Southeastern Alaska; Bureau of Mines Report of Investigations 4373, 5 p.

Foley, J.Y., 1992, Ophiolite and Other Ultramafic Metallogenic Provinces in Alaska (west of the 141th meridian); U.S. Geological Survey Open-File Report 92-20B , 65 p.

Foley, J.Y., and Barker, J.C., 1985, Chromite Deposits Along the Border Ranges Fault, Southern Alaska. (In Two Parts.) 1. Field Investigations and Descriptions of Chromite Deposits; Bureau of Mines Information Circular 8990, 58 p.

Foster, R.L., and Chapman, R.M., 1967, Locations and Descriptions of Lode Prospects in the Livengood Area, East-Central Alaska; U.S. Geological Survey Open-File Report 67-91, 6 p.

Fowler, H.M., 1950, Snettisham Iron Deposit; Alaska Territorial Department of Mines Mineral Investigations MI-115-1, 3 p., 1 map.

Gill, A.C., 1922, Chromite of Kenai Peninsula, Alaska; U.S. Geological Survey Bulletin 742, 52 p.

Gill, A.C., 1920, Preliminary Report on the Chromite of Kenai Peninsula; U.S. Geological Survey Bulletin 712, p. 99-129.

Glover, A.E., 1954, Kelp and Duke Islands Magnetics; Alaska Territorial Department of Mines Mineral Investigations MI-122-2, $1 \mathrm{p}$.

Glover, A.E., 1954, Tah Bay Reconnaissance (Prince of Wales Island); Alaska Territorial Department of Mines Mineral Investigations MI-121-1, 3 p.

Gonnason Exploration Co., 1963, Magnetometer Survey Jumbo Mine (Prince of Wales Island); Alaska Territorial Department of Mines Miscellaneous Report MR-119-4, 5 p., 2 maps.

Grant, U.S., and Higgins, D.F., 1910, Preliminary Report on the Mineral Resources of the Southern Part of Kenai Peninsula; U.S. Geological Survey Bulletin 442, p. 166-178.

Grantz, A., 1956, Magnetite Deposits at Tuxedni Bay, Alaska; U.S. Geological Survey Bulletin 1024-D, $11 \mathrm{p}$.

Guild, P.W., 1942, Chromite Deposits of Kenai Peninsula, Alaska; U.S. Geological Survey Bulletin 931-G, p. 139-175.

Holdsworth, P.R., 1954, Investigation of Claim Staking (Union Bay Area); Alaska Territorial Department of Mines Prospect Evaluation PE-119-23.

Holt, S.P., and Erickson, A.E., 1945, Tolstoi Mountain, Kasaan Peninsula, Prince of Wales Island, Southeastern Alaska; Bureau of Mines War Minerals Report 361, 6 p. 
Holt, S.P., Thorne, R.L., Erickson, A.R., and Tolonen A.W., 1944, Poor Man Iron Deposit, Kasaan Peninsula, Prince of Wales Island, Southeastern Alaska; Bureau of Mines War Minerals Report 227, 27 p.

Holt, S.P., Wright, W.S., and Fosse, E.L., 1945, Jumbo Basin, Prince of Wales Island, Southeastern Alaska--Iron, Copper; Bureau of Mines War Minerals Report 447, 13 p.

Howard, A.L., 1935, Rush and Brown-Salt Chuck (Alaska Gold and Metals Co., Kasaan Bay); Alaska Territorial Department of Mines Miscellaneous Report MR-119-2, 8 p.

Howard, A.L., 1935, Salt Chuck Mine (Alaska Gold and Metals Co., Kasaan Bay); Alaska Territorial Department of Mines Miscellaneous Report MR-119-2A, 14 p., 1 map.

Huber, Jeff, 1999, Alaska Resource Data File-Seldovia Quadrangle; U.S. Geological Survey Open-File Report 99-391, 70 p.

Hudson, T.L., Miller, M.L., and Peckthorn, W.J., 1977, Map Showing Metalliferous and Selected Nonmetalliferous Mineral Deposits, Seward Peninsula, Alaska; U.S. Geological Survey Open-File Report 77-796-B, 46 p., 1 sheet, scale 1:1,000,000.

Humble Oil and Refining Co., 1959, Kemuk Mountain Iron Ore Prospect; Alaska Territorial Department of Mines Miscellaneous Report MR-102-1, 12 p., 4 maps.

Irvine, T.N., 1974, Petrology of the Duke Island Ultramafic Complex, Southeastern Alaska; Geological Society of America Memoir 138, 240 p.

Jasper, M.W., and Saunders, R.H., 1955, Reconnaissance of Upper Butte Creek (Susitna River); Alaska Territorial Department of Mines Mineral Investigation MI-67-2, 5 p.

Kaufman, A., 1958, Southeastern Alaska's Mineral Industry; Bureau of Mines Information Circular 7844, $37 \mathrm{p}$.

MacKevett, E.M., Jr., 1976, Mineral Deposits and Occurrences in the McCarthy Quadrangle, Alaska; U.S. Geological Survey Miscellaneous Field Studies Map MF-773-B, 1 sheet, scale 1:250,000.

MacKevett, E.M., Jr., and Blake, M.C., Jr., 1963, Geology of the North Bradfield River Iron Prospect, Southeastern Alaska; U.S. Geological Survey Bulletin 1108-D, 21 p., 1 sheet, scale 1:12,000.

MacKevett, E.M., Jr., and Cobb, E.H., 1972, Metallic Mineral Resources Map of the McCarthy Quadrangle, Alaska; U.S. Geological Survey Miscellaneous Field Studies Map MF-395, 1 sheet, scale 1:250,000.

MacKevett, E.M., Jr., and Holloway, C.D., 1977, Map Summarizing Metalliferous and Selected Nonmetalliferous Mineral Deposits in the Eastern Part of Southern Alaska; U.S. Geological Survey Open-File Report 77-169-A, 99 p., 1 sheet, 1:1,000,000.

MacKevett, E.M., Jr., Brew, D.A., Hawley, C.C., Huff, L.C., and Smith, J.G., 1967, Mineral Resources of Glacier Bay National Monument, Alaska; U.S. Geological Survey Open-File Report 67-151, 176 p., 10 sheets, scale 1:125,000.

MacKevett, E.M., Jr., Brew, D.A., Hawley, C.C., Huff, L.C., and Smith, J.G., 1971, Mineral Resources of Glacier Bay National Monument, Alaska; U.S. Geological Survey Professional Paper 632, 90 p., 8 sheets, scale 1:250,000.

Martin, G.C., 1920, The Alaskan Mining Industry in 1918; U.S. Geological Survey Bulletin 712, p. 11-52. 
Martin, G.C., and others, 1915, Geology and Mineral Resources of Kenai Peninsula, Alaska; U.S.

Geological Survey Bulletin 587, 243 p.

Mertie, J.B., Jr., 1919, Chromite Deposits in Alaska; U.S. Geological Survey Bulletin 692, p. 265-267.

Miller, D.L., 1961, Geology of the Yakutat District, Gulf of Alaska Tertiary Province, Alaska; U.S. Geological Survey Open-File Report 61-103, 2 sheets, scale 1:96,000.

Nockleberg, W.J., Bundtzen, T.K., Berg, H.C., Brew, D.A., Grybeck, D., Robinson, M.S., Smith, T.E., and Yeend, W., 1987, Significant Metalliferous Lode Deposits and Placer Districts of Alaska; U.S. Geological Survey Bulletin 1786, 104 p.

Noel, G.A., 1963, Peacock Fraction; Alaska Division of Geological \& Geophysical Surveys Miscellaneous Report MR-119-5, 6 p.

Payne, T.G., Dana, S., Fischer, W., Gryc, G., Lathram, E., Morris, R., Tappan, H., and Yuster, S., 1952, Geology of the Arctic Slope of Alaska; U.S. Geological Survey Oil and Gas Investigations Map 126,1 sheet, scale 1:1,000,000.

Pillmore, C.L., and McQueen, K., 1956, Map of Salt Chuck Area, Prince of Wales Island, Alaska, Showing Linear Features as Seen on Aerial Photographs; U.S. Geological Survey Miscellaneous Geologic Investigations Series Map I-230, 1 sheet, scale 1:12,000.

Race, W.H., 1963, H. Stelting Iron Deposit; Alaska Division of Geological \& Geophysical Surveys Prospect Evaluation PE-109-5, 7 p.

Richter, D.H., and Matson, N.A., Jr., 1972, Metallic Mineral Resources Map of the Gulkana Quadrangle, Alaska; U.S. Geological Survey Miscellaneous Field Studies Map MF-419, 1 sheet, scale $1: 250,000$.

Roberts, W.S., 1984, Economic Potential for Chromium, Platinum, and Palladium in the Mount Hurst Ultramafics, West-Central Area, Alaska; Bureau of Mines Open-File Report 22-84, 52 p.

Robertson, E.C., 1956, Magnetite Deposits Near Klukwan and Haines, Alaska; U.S. Geological Survey Open-File Report 56-101, 37 p., 11 sheets, scales 1:9,000, 1:3,168,000, 1:4,500, 1:600, and $1: 18,000$.

Roehm, J.C., 1938, Copper Came Group (Karta Bay); Alaska Territorial Department of Mines Prospect Evaluation PE-119-10, 2 p.

Roehm, J.C., 1938, Copper Center Prospect (Kasaan Peninsula); Alaska Territorial Department of Mines Prospect Evaluation PE-119-9, 2 p.

Roehm, J.C., 1938, Mucker's Dream Group (Windfall Bay); Alaska Territorial Department of Mines Prospect Evaluation PE-119-14, 3 p.

Roehm, J.C., 1938, Shepard Group (Kasaan Peninsula); Alaska Territorial Department of Mines Prospect Evaluation PE-119-11, 2 p.

Roehm, J.C., 1938, Venus Group (Karta Bay); Alaska Territorial Department of Mines Prospect Evaluation PE-119-12, 2 p.

Roehm, J.C., 1939, Jack Wilcox Gold Prospect (Nutkwa Property, Nutkwa Bay); Alaska Territorial Department of Mines Prospect Evaluation PE-119-18, 4 p., 2 maps. 
Roehm, J.C., 1941, Iron Capor Mahoney Prospect (Tolstoi Bay); Alaska Territorial Department of Mines Prospect Evaluation PE-119-19, 2 p.

Rossman, D.L, 1957, Ilmenite-Bearing Beach Sands Near Lituya Bay, Alaska; U.S. Geological Survey Open-File Report 57-98, 11 p., 1 sheet, scale 1:125,000.

Rossman, D.L., Henderson, J.R., Jr., and Walton, M.S., Jr., 1956, Reconnaissance Total Intensity Aeromagnetic Map of the Southern Part of Prince of Wales Island, Alaska; U.S. Geological Survey Geophysical Investigations Map GP-135, 1 sheet, scale 1:126,720.

Ruckmick, J.C., and Noble, J.A., 1959, Origin of the Ultramafic Complex at Union Bay, Southeastern Alaska; Geological Society of America Bulletin 5908, 36 p.

Rutledge, F.A., 1946, Exploration of Red Mountain Chromite Deposits, Kenai Peninsula, Alaska; Bureau of Mines Report of Investigations 3885, $26 \mathrm{p}$.

Rutledge, F.A., 1953, Investigation of the Copper Bullion Claims, Rua Cove, Knight Island, Alaska; Bureau of Mines Report of Investigations 4986, 6 p.

Sanford, R.S., 1944, Red Mountain Chromite Deposits, Kenai Peninsula, Alaska; Bureau of Mines War Minerals Report 191, 51 p.

Sanford, R.S., and Cole, J.W., 1941, Investigation of the Claim Point Chromite Deposits, Kenai Peninsula, Alaska; Bureau of Mines Report of Investigations 4419, 11 p.

Sanford, R.S., and Cole, J.W., 1943, Claim Point Chromite Deposit, Kenai Peninsula, Alaska; Bureau of Mines War Minerals Report 253, 34 p.

Shepard, J.G., 1926, Ketchikan District Properties; Alaska Territorial Department of Mines Miscellaneous Report MR-191-1A, 18 p.

Still, J.C., 1984, Copper, Gold, Platinum, and Palladium Sample Results From the Klukwan Mafic/ Ultramafic Complex, Southeast Alaska; Bureau of Mines Open-File Report 21-84, 53 p.

Storm, L.W., 1917, Report on the Dundas Bay Iron Property; Alaska Juneau Gold Mining Co.

Taylor, H.P., and Noble, J.A., 1960, Origin of the Ultramafic Complexes in Southeastern Alaska; International Geological Congress, 21st, Copenhagen, Report, p. 175-187.

Thomas, B.I., and Berryhill, R.V., 1962, Reconnaissance Studies of Alaskan Beach Sands, Eastern Gulf of Alaska; Bureau of Mines Report of Investigations 5986, 40 p.

Thorne, R.L., and Wells, R.R., 1956, Studies of the Snettisham Magnetite Deposit, Southeastern Alaska; Bureau of Mines Report of Investigations 5195, 41 p.

Twenhofel, W.S., 1953, Potential Alaska Mineral Resources for Proposed Electrochemical and Electrochemical and Eletrometallurgical Industries in the Upper Lynn Canal Area, Alaska; U.S. Geological Survey Circular 252, 14 p.

Tysdal, R.G., 1979, Mines, Prospects, and Occurrences Map of the Seward and Blying Sound Quadrangles, Alaska; U.S. Geological Survey Miscellaneous Field Studies Map MF-880-A, 2 sheets, scale $1: 125,000$.

U.S. Bureau of Mines, 1943, Molybdenum Deposits, Muir Inlet, Alaska; Bureau of Mines War Minerals Report 40, 7 p. 
U.S. Bureau of Mines, 1945, Mount Andrew Iron Deposit, Kasaan Peninsula, Prince of Wales Island, Southeastern Alaska; Bureau of Mines Draft War Minerals Report 4504.

U.S. Bureau of Mines, 1945, Rush and Brown Mine, Kasaan Bay, Prince of Wales Island, Southeastern Alaska; Bureau of Mines War Minerals Report 455, 9 p.

U.S. Bureau of Mines, 1945, Salt Chuck Mine, Kasaan Peninsula, Prince of Wales Island, Southeastern Alaska--Copper, Palladium; Bureau of Mines War Minerals Report 423, 17 p.

U.S. Bureau of Mines, 1973, Alaska 1:250,000 Scale Quadrangle Map Overlays Showing Mineral Deposit Locations, Principal Minerals, and Number and Type of Claims; Bureau of Mines Open-File Report 20-73, $41 \mathrm{p}$.

U.S. Bureau of Mines, 1974, Claim Map, Prince Rupert; U.S. Bureau of Mines Map, no. 122, 1 sheet, scale $1: 250,000$.

U.S. Bureau of Mines, 1985, Unpublished data, 1970-1985.

U.S. Geological Survey, 1971, Geological Survey Research 1971; U.S. Geological Survey Professional Paper 750-D, $223 \mathrm{p}$.

Warfield, R.S., and Rutledge, F.A., 1951, Investigation of Kasna Creek Copper Prospect, Lake Kontrashibuna, Lake Clark Region, Alaska; Bureau of Mines Report of Investigations 4828, 10 p.

Warner, L.A., Goddard, E.N., Walton, M.S., Jr., Bressler, C.T., and Stefansson, K. , 1961, Ra-Iron and Copper Deposits of Kasaan Peninsula, Prince of Wales Island, Southeastern Alaska; U.S. Geological Survey Bulletin 1090, 136 p., 28 sheets, scale 1:63,360.

Wells, R.R., and Thorne, R.L., 1953, Concentration of Klukwan, Alaska, Magnetite Ore; Bureau of Mines Report of Investigations 4984, 15 p.

Wells, R.R., Sterling, F.T., Erspamer, E.G., and Stickney, W.A., 1957, Laboratory Concentration of Chromite Ores, Red Mountain District, Kenai Peninsula, Alaska; Bureau of Mines Report of Investigations 5377, $22 \mathrm{p}$.

Wilcox, H.G., 1938, Kasaan Gold Property (Twelve Mile Arm, Harris Creek); Alaska Territorial Department of Mines Prospect Evaluation PE-119-5, 2 p.

Williams, J.A., 1952, Snettisham Magnetic Survey; Alaska Territorial Department of Mines Prospect Evaluation PE-115-3, $10 \mathrm{p}$.

Williams, J.A., 1953, Snettisham Magnetic Survey (Port Snettisham); Alaska Territorial Department of Mines Prospect Evaluation PE-115-5, 25 p., 1 sheet, scale 1:3,000.

Wright, W.S., and Fosse, E.L., 1946, Exploration of the Jumbo Basin Iron Deposit, Prince of Wales Island, Southeastern Alaska; Bureau of Mines Report of Investigations 3952, 9 p.

\section{Magnesium}

Barker, J.C., Still, J.C., Mowatt, T.C., and Mulligan, J.J., 1981, Critical and Strategic Minerals in Alaska: Cobalt, the Platinum-Group Metals, and Chromite; Bureau of Mines Information Circular 8869, 8 p., 1 sheet, scale 1:250,000.

Carnes, R.D., 1976, Active Alaskan Placer Operations, 1975; Bureau of Mines Open-File Report 98-76. 
Cobb, E.H., 1972, Metallic Mineral Resources Map of the Anchorage Quadrangle, Alaska; U.S. Geological Survey Miscellaneous Field Studies Map MF-409, 1 sheet, scale 1:250,000.

Cobb, E.H., 1972, Metallic Mineral Resources Map of the Eagle Quadrangle, Alaska; U.S. Geological Survey Miscellaneous Field Studies Map MF-393, 1 sheet, scale 1:250,000.

Cobb, E.H., 1972, Metallic Mineral Resources Map of the Nome Quadrangle, Alaska; U.S. Geological Survey Miscellaneous Field Studies Map MF-463, 1 sheet, scale 1:250,000.

Cobb, E.H., 1972, Metallic Mineral Resources Map of the Sumdum Quadrangle, Alaska; U.S. Geological Survey Miscellaneous Field Studies Map MF-425, 1 sheet, scale 1:250,000.

Cobb, E.H., 1973, Metallic Mineral Resources Map of the Craig Quadrangle, Alaska; U.S. Geological Survey Miscellaneous Field Studies Map MF-433, 1 sheet, scale 1:250,000.

Cobb, E.H., 1980, Summaries of Data on and Lists of References to Metallic and Selected Nonmetallic Mineral Deposits in the McCarthy Quadrangle, Alaska; U.S. Geological Survey Open-File Report $80-885,157 \mathrm{p}$.

Holt, S.P., Thorne, R.L., Erickson, A.R., and Tolonen, A.W., 1944, Poor Man Iron Deposit, Kasaan Peninsula, Prince of Wales Island, Southeastern Alaska; Bureau of Mines War Minerals Report 227, $27 \mathrm{p}$.

Hudson, T.L., Miller, M.L., and Peckthorn, W.J., 1977, Map Showing Metalliferous and Selected Nonmetalliferous Mineral Deposits, Seward Peninsula, Alaska; U.S. Geological Survey Open-File Report 77-796-B, 46 p., 1 sheet, scale 1:1,000,000.

Kaufman, A., 1958, Southeastern Alaska's Mineral Industry; Bureau of Mines Information Circular 7844, $37 \mathrm{p}$.

MacKevett, E.M., Jr., 1976, Mineral Deposits and Occurrences in the McCarthy Quadrangle, Alaska; U.S. Geological Survey Miscellaneous Field Studies Map MF-773-B, 1 sheet, scale 1:250,000.

Roberts, W.S., 1984, Economic Potential for Chromium, Platinum, and Palladium in the Mount Hurst Ultramafics, West-Central Area, Alaska; Bureau of Mines Open-File Report 22-84, 52 p.

Thorne, R.L., and Wells, R.R., 1956, Studies of the Snettisham Magnetite Deposit, Southeastern Alaska; Bureau of Mines Report of Investigations 5195, 41 p.

Warner, L.A., Goddard, E.N., and others, 1961, Iron and Copper Deposits of Kasaan Peninsula, Prince of Wales Island, Southeastern Alaska; U.S. Geological Survey Bulletin 1090, 136 p., 28 sheets, scale $1: 63,360$.

\section{Manganese}

Barker, J.C., 1978, Mineral Investigations of Certain Lands in the Eastern Brooks Range, 1978: A Summary Report; Bureau of Mines Open-File Report 63-78, 25 p.

Barker, J.C., 1981, Mineral Investigations in the Porcupine River Drainage, Alaska; U.S. Bureau of Mines Open-File Report 27-81, 189 p.

Barker, J.C., and Clautice, K.H., 1978, Mineral Reconnaissance of the Porcupine River Region: A Summary Report; U.S. Bureau of Mines Open File Report 87-78, 20 p.

Barnwell, C.E., 1990, Arctic Slope Consulting Engineers; Written Communication, July 1990. 
Barnwell, C.E., Simpson, S., and Church, S.E., 1989, Analytical Results and Sample Locality Maps of Stream-Sediment and Rock Samples from the Cobblestone Creek Area, Southeastern Chandler Lake Quadrangle, Alaska; U.S. Geological Survey Open-File Report 89-540, 26 p.

Bird, K.J., and Molenaar, C.M., 1987, Chapter 5, Stratigraphy (in) Bird, K.J., and Magoon, L.B. (eds.), Petroleum Geology of the Northern Part of the Arctic Wildlife Refuge, Northeastern Alaska; U.S. Geological Survey Bulletin 1778, p. 37-59.

Bundtzen, T.K., Eakins, G.R., and Conwell, C.N., 1982, Review of Alaska's Mineral Resources; Alaska Division of Geological \& Geophysical Surveys and Alaska Department of Commerce and Economic Development, AMR 81-82.

Clark, A.L., and Cobb, E.H., 1972, Metallic Mineral Resources Map of the Healy Quadrangle, Alaska; U.S. Geological Survey Miscellaneous Field Studies Map MF-394, 1 sheet, scale 1:250,000.

Cobb, E.H., 1968, Metallic Mineral Resources Map of the Hughes Quadrangle, Alaska; U.S. Geological Survey Open-File Report 68-44, 4 p., 1 sheet, scale 1:250,000.

Cobb, E.H., 1972, Metallic Mineral Resources Map of the Iliamna Quadrangle, Alaska; U.S. Geological Survey Miscellaneous Field Studies Map MF-364, 1 sheet, scale 1:250,000.

Cobb, E.H., 1972, Metallic Mineral Resources Map of the Livengood Quadrangle, Alaska; U.S. Geological Survey Miscellaneous Field Studies Map MF-413, 1 sheet, scale 1:250,000.

Cobb, E.H., 1972, Metallic Mineral Resources Map of the Mount McKinley Quadrangle, Alaska; U.S. Geological Survey Miscellaneous Field Studies Map MF-366, 1 sheet, scale 1:250,000.

Cobb, E.H., 1972, Metallic Mineral Resources Map of the Tanana Quadrangle, Alaska; U.S. Geological Survey Miscellaneous Field Studies Map MF-371, 1 sheet, scale 1:250,000.

Cobb, E.H., and Matson, N.A., Jr., 1972, Metallic Mineral Resources Map of the Valdez Quadrangle, Alaska; U.S. Geological Survey Miscellaneous Field Studies Map MF-438, 1 sheet, scale $1: 250,000$.

Cobb, E.H., Mayfield, C.F., Brosge, W.P., 1981, Summaries of Data on and Lists of References to Metallic and Selected Non-Metallic Mineral Occurrences in Eleven Quadrangles in Northern Alaska-Summaries of Data to January 1, 1981; U.S. Geological Survey Open-File Report 81-767, 40 p.

Detterman, R.L., Reiser, H.N., Brosge', W.P., and Dutro, J.T., Jr., 1975, Post-Carboniferous Stratigraphy, Northeastern Alaska; U.S. Geological Survey Professional Paper 886, 46 p.

Dover, J., 1997, Alaska Resource Data File-Colleen Quadrangle; U.S. Geological Survey Open-File Report 97-295, $39 \mathrm{p}$.

Force, E.R., and Cannon, W.F., 1988, Depositional Model for Shallow-Marine Manganese Deposits Around Black Shale Basins; Economic Geology, v. 83, p. 93-117.

Govier, R.D., 1994, Bureau of Mines, Research Center, Salt Lake City, Utah; Written Communication, January 1994.

Grybeck, D.J., 1977, Map Showing Known Mineral Deposits of the Brooks Range, Alaska, U.S. Geological Survey Open-File Report 77-166-C, 45 p., 1 sheet, scale 1:1,000,000. 
Jansons, U., and Parke, M.A., 1980, 1978 Mineral Investigations of Misheguk Mountain and Howard Pass Quadrangles, Alaska; Bureau of Mines Open File Report 26-81, 193 p.

Kelley, J.S., 1996, Alaska Resource Data File-Demarcation Point Quadrangle; U.S. Geological Survey Open-File Report 96-678, 14 p.

Kelley, K.D., 1997, Alaska Resource Data File-Chandler Lake Quadrangle; U.S. Geological Survey OpenFile Report 97-265, 24 p.

Kelley, K.D., 1997, Alaska Resource Data File-Killik River Quadrangle; U.S. Geological Survey Open-File Report 97-266, 20 p.

Kurtak, J.M., 1982, A Manganese Occurrence on Chenega Island, Prince William Sound, Alaska; Bureau of Mines MLA 124-82, 9 p.

Kurtak, J.M., Hicks, R.W., Werdon, M.B., Meyer, M.P., and Mull, C.G., 1995, Mineral Investigations in the Colville Mining District and Southern National Petroleum Reserve in Alaska; Bureau of Mines Open-File Report 8-95, 217 p., 1 sheet, scale 1:250,000.

MacKevett, E.M., Jr., and Holloway, C.D., 1977, Map Showing Metalliferous Mineral Deposits in the Western Part of Southern Alaska; U.S. Geological Survey Open-File Report 77-169-F, 39 p., 1 sheet, scale 1:1,000,000.

Meyer, M.P., 1994, Analytical Results from U.S. Bureau of Mines Investigations in the Colville Mining District, Alaska; U.S. Bureau of Mines Open-File Report 34-94, 137 p.

Meyer, M.P., and Kurtak, J.M., 1992, Results of the 1991 U.S. Bureau of Mines Colville Mining District Study; U.S. Bureau of Mines Open-File Report 75-92, 101 p.

Plafker, G., and MacKevett, E.M., Jr, 1969, Mafic and Ultramafic Rocks From a Layered Pluton at Mt. Fairweather, Alaska; U.S. Geological Survey Open-File Report 69-208, 10 p.

Reed, B.L., and Lanphere, M.A., 1972, Generalized Geologic Map of the Alaska Aleutian Range Batholith Showing Potassium-Argon Ages of the Plutonic Rocks; U.S. Geological Survey Miscellaneous Field Studies Map MF-372, 2 sheets, 1:1,000,000.

Roehm, J.C., 1938, Children Group (Hungerford Creek); Alaska Territorial Department of Mines Prospect Evaluation PE-116-1, 2 p.

Seplocha, S., 1982, Manganese Found on Chenega Island; Anchorage Daily News, December 11, 1982, $2 \mathrm{p}$.

Thomas, B.I., 1965, Reconnaissance Sampling of the Avnet Manganese Prospect, Tanana Quadrangle, Central Alaska; Bureau of Mines Open-File Report 10-65, 8 p.

Tysdal, R.G., 1979, Mines, Prospects, and Occurrences Map of the Seward and Blying Sound Quadrangles, Alaska; U.S. Geological Survey Miscellaneous Field Studies Map MF-880-A, 2 sheets, scale $1: 250,000$.

U.S. Bureau of Mines, 1995, Spatial Data Extracted from the Minerals Availability System/ Mineral Industry Location System (MAS/MILS); U.S. Bureau of Mines Special Publication 12-95, CDROM.

U.S. Geological Survey, 1990, Generalized Geologic Map of the Chandler Lake Quadrangle, North-Central Alaska; U.S. Geological Survey Miscellaneous Field Studies Map MF-2144-A. 
U.S. Geological Survey, 1993, U.S. Geological Survey, Anchorage, Alaska; Written Communication, October 1993.

\section{Rare Earth Elements}

Alaska Department of Revenue, 1985, Mine License Application.

Alaska Economic Report (Anchorage), 1979, Alaska Mineral Exploration Increasing, but Land Uncertainties Cloud Future; Alaska Economic Report May 15, 1979, 8 p.

Armbrustmacher, T.J., 1989, Minor Element Content, Including Radioactive Elements and Rare-Earth Elements, in Rocks from the Syenite Complex at Roy Creek, Mount Prindle Area, Alaska; U.S. Geological Survey Open-File Report 89-0146, 11 p.

Barker, J.C., 1981, Mineral Investigations in the Porcupine River Drainage, Alaska; U.S. Bureau of Mines Open-File Report 27-81, 189 p.

Barker, J.C., and Clautice, K.H., 1978, Mineral Reconnaissance of the Porcupine River Region: A Summary Report; U.S. Bureau of Mines Open File Report 87-78, 20 p.

Barker, J.C., and Warner, J.D., 1988, USBM Inventories Alaskan Rare Earths Deposits; Engineering \& Mining Journal, v.189, no.2, p. 42-43.

Berg, H.C., Decker, J.E., and Abramson, B.S., 1981, Metallic Mineral Deposits of Southeastern Alaska; U.S. Geological Survey Open-File Report 81-122, 145 p., 1 sheet, scale 1:1,000,000.

Brooks, A.H., and others, 1923, Mineral Resources of Alaska, Report on Progress of Investigations in 1921; U.S. Geological Survey Bulletin 739, 182 p.

Bundtzen, T.K., Eakins, G.R., and Conwell, C.N., 1982, Review of Alaska's Mineral Resources; Alaska Division of Geological \& Geophysical Surveys and Alaska Department of Commerce and Economic Development, AMR 81-82.

Cobb, E.H., 1972, Metallic Mineral Resources Map of the Bethel Quadrangle, Alaska; U.S. Geological Survey Miscellaneous Field Studies Map MF-455, 1 sheet, scale 1:250,000.

Cobb, E.H., 1972, Metallic Mineral Resources Map of the Chandalar Quadrangle, Alaska; U.S. Geological Survey Miscellaneous Field Studies Map MF-457, 1 sheet, scale 1:250,000.

Cobb, E.H., 1972, Metallic Mineral Resources Map of the Circle Quadrangle, Alaska; U.S. Geological Survey Miscellaneous Field Studies Map MF-391, 1 sheet, scale 1:250,000.

Cobb, E.H., 1972, Metallic Mineral Resources Map of the Coleen Quadrangle, Alaska; U.S. Geological Survey Miscellaneous Field Studies Map MF-403, 1 sheet, scale 1:250,000.

Cobb, E.H., 1972, Metallic Mineral Resources Map of the Dixon Entrance Quadrangle, Alaska; U.S. Geological Survey Miscellaneous Field Studies Map MF-434, 1 sheet, scale 1:250,000.

Cobb, E.H., 1972, Metallic Mineral Resources Map of the Eagle Quadrangle; Alaska, U.S. Geological Survey Miscellaneous Field Studies Map MF-393, 1 sheet, scale 1:250,000.

Cobb, E.H., 1972, Metallic Mineral Resources Map of the Icy Bay Quadrangle, Alaska; U.S. Geological Survey Miscellaneous Field Studies Map MF-411, 1 sheet, scale 1:250,000. 
Cobb, E.H., 1972, Metallic Mineral Resources Map of the Iditarod Quadrangle, Alaska; U.S. Geological Survey Miscellaneous Field Studies Map MF-363, 1 sheet, scale 1:250,000.

Cobb, E.H., 1972, Metallic Mineral Resources Map of the Iliamna Quadrangle, Alaska; U.S. Geological Survey Miscellaneous Field Studies Map MF-364, 1 sheet, scale 1:250,000.

Cobb, E.H., 1972, Metallic Mineral Resources Map of the Juneau Quadrangle, Alaska; U.S. Geological Survey Miscellaneous Field Studies Map MF-435, 1 sheet, scale 1:250,000.

Cobb, E.H., 1972, Metallic Mineral Resources Map of the Mount Fairweather Quadrangle, Alaska; U.S. Geological Survey Miscellaneous Field Studies Map MF-436, 1 sheet, scale 1:250,000.

Cobb, E.H., 1972, Metallic Mineral Resources Map of the Mt. Michelson Quadrangle, Alaska; U.S. Geological Survey Miscellaneous Field Studies Map MF-462, 1 sheet, scale 1:250,000.

Cobb, E.H., 1972, Metallic Mineral Resources Map of the Petersburg Quadrangle, Alaska; U.S. Geological Survey Miscellaneous Field Studies Map MF-415, 1 sheet, scale 1:250,000.

Cobb, E.H., 1972, Metallic Mineral Resources Map of the Ruby Quadrangle, Alaska; U.S. Geological Survey Miscellaneous Field Studies Map MF-405, 1 sheet, scale 1:250,000.

Cobb, E.H., 1972, Metallic Mineral Resources Map of the Solomon Quadrangle, Alaska; U.S. Geological Survey Miscellaneous Field Studies Map MF-445, 1 sheet, scale 1:250,000.

Cobb, E.H., 1972, Metallic Mineral Resources Map of the Tanana Quadrangle, Alaska; U.S. Geological Survey Miscellaneous Field Studies Map MF-371, 1 sheet, scale 1:250,000.

Cobb, E.H., 1975, Summary of References to Mineral Occurrences (other than mineral fuels and construction materials) in Northern Alaska; U.S. Geological Survey Open-File Report 75-628, 106 p.

Cobb, E.H., 1978, Summary of References to Mineral Occurrences (Other Than Mineral Fuels and Construction Materials) in the Solomon Quadrangle, Alaska; U.S. Geological Survey Open-File Report 78-181, $185 \mathrm{p}$.

Dover, J., 1997, Alaska Resource Data File-Colleen Quadrangle; U.S. Geological Survey Open-File Report 97-295, $39 \mathrm{p}$.

Eakins, G.R., 1969, Uranium in Alaska; Alaska Division of Geological \& Geophysical Surveys Geologic Report 38, 49 p., 1 sheet, scale 1:3,800,000.

Eakins, G.R., 1970, An Experiment in Geobotanical Prospecting for Uranium, Bokan Mountain Area, Southeastern Alaska; Alaska Division of Geological \& Geophysical Surveys Geologic Report 41, $51 \mathrm{p}$.

Eakins, G.R., and Forbes, R.B., 1976, Investigation of Alaska's Uranium Potential; Alaska Division of Geological \& Geophysical Surveys Special Report 12, 372 p., 5 sheets, scale 1:1,000,000.

Glover, A.E., 1951, Salmon Bay-Red Bay Reconnaissance (Prince of Wales Island); Alaska Territorial Department of Mines Mineral Investigation MI-117-1, 6 p.

Heiner, L.E., and Wolff, E.N., 1968, Mineral Resources of Northern Alaska, Final Report Submitted to the North Commission; Mineral Industry Research Laboratory, University of Alaska, Report 16, 306 p., 3 sheets, scales 1:1,000,000 and 1:5,000,000. 
Heylmun, E.B., 1999, Rare Earths at Bokan Mountain, Alaska; International California Mining Journal, January 1999 , p. 44-46.

Hudson, T.L., Miller, M.L., and Peckthorn, W.J., 1977, Map Showing Metalliferous and Selected Nonmetalliferous Mineral Deposits, Seward Peninsula, Alaska; U.S. Geological Survey Open-File Report 77-796-B, 46 p., 1 sheet, scale 1:1,000,000.

Kelley, J.S., 1996, Alaska Resource Data File-Demarcation Point Quadrangle; U.S. Geological Survey Open-File Report 96-678, 14 p.

Lathram, E.H., Loney, R.A., Condon, W.H., and Berg, H.C., 1959, Progress Map of the Geology of the Juneau Quadrangle, Alaska; U.S. Geological Survey Geologic Investigations Series Map I-303, 1 sheet, scale 1:250,000.

MacKevett, E.M., Jr., 1959, Geology of the Ross-Adams Uranium-Thorium Deposit, Alaska; Mining and Engineering (N.Y.) 5909.

Maloney, R.P., 1962, Investigation of Mercury-Antimony Deposits Near Flat, Yukon River Region, Alaska; Bureau of Mines Report of Investigations 5991, 44 p.

Staatz, M.H., Hall, R.B. Hall, Macke, D.L., Armbrustmacher, T.J., and Brownfield, I.K., 1980, Thorium Resources of Selected Regions in the United States; U.S. Geological Survey Circular 824, 32 p.

Thomas, B., 1948, Nixon Fork Mining District; Alaska Territorial Department of Mines Miscellaneous Report MR-65-2, 43 p.

Thorne, R.L., and Wright, W.S., 1948, Sampling Methods and Results at the Sullivan Creek Tin Placer Deposits, Manley Hot Springs, Tofty, Alaska; Bureau of Mines Report of Investigations 4346, 8 p.

Tourtelot, H.A., and Tailleur, I.L., 1971, The Shublik Formation and Adjacent Strata in Northwestern Alaska; U.S. Geological Survey Open-File Report 71-284, 62 p.

U.S. Bureau of Mines, 1995, Spatial Data Extracted from the Minerals Availability System/ Mineral Industry Location System (MAS/MILS); U.S. Bureau of Mines Special Publication 12-95, CDROM.

Wallace Miner, 1970, Dawn Uses Option for Sale of Uranium Oxide; Wallace Miner.

Warner, J.D., 1989, Columbium-, Rare-Earth-Element-, and Thorium-Bearing Veins Near Salmon Bay, Southeastern Alaska; U.S. Bureau of Mines Open-File Report 06-89, 25 p.

Wedow, H., Jr., and others, 1953, Preliminary Summary of Reconnaissance for Uranium and Thorium in Alaska, 1952; U.S. Geological Survey Circular 248, 15 p., 1 sheet, scale 1:11,088,000.

Williams, J.A., 1955, Carol Anne Property (Kendrick Bay); Alaska Territorial Department of Mines Prospect Evaluation PE-121-7, 5 p.

\section{Thorium}

Alaska Economic Report (Anchorage), 1979, Alaska Mineral Exploration Increasing, but Land Uncertainties Cloud Future; Alaska Economic Report May 15, 1979, 8 p.

Armbrustmacher, T.J., 1989, Minor Element Content, Including Radioactive Elements and Rare-Earth Elements, in Rocks from the Syenite Complex at Roy Creek, Mount Prindle Area, Alaska; U.S. Geological Survey Open-File Report 89-0146, 11 p. 
Barker, J.C., 1981, Mineral Investigations in the Porcupine River Drainage, Alaska; U.S. Bureau of Mines Open-File Report 27-81, 189 p.

Barker, J.C., and Clautice, K.H., 1978, Mineral Reconnaissance of the Porcupine River Region: A Summary Report; U.S. Bureau of Mines Open File Report 87-78, 20 p.

Barker, J.C., and Warner, J.D., 1988, USBM Inventories Alaskan Rare Earths Deposits; Engineering \& Mining Journal, v.189, no.2, p. 42-43.

Berg, H.C., and Cobb, E.H., 1967, Metalliferous Lode Deposits of Alaska; U.S. Geological Survey Bulletin $1246,254 \mathrm{p}$.

Berg, H.C., Decker, J.E., and Abramson B.S., 1981, Metallic Mineral Deposits of Southeastern Alaska; U.S. Geological Survey Open-File Report 81-122, 145 p., 1 sheet, scale 1:1,000,000.

Brosge', W.R., and Reiser, H.N., 1968, Geochemical Maps of Granitic Rocks, Coleen and Table Mountain Quadrangles, Alaska; U.S. Geological Survey Open-File Report 323, 1 sheet, scale 1:250,000.

Bundtzen, T.K., Eakins, G.R., and Conwell, C.N., 1982, Review of Alaska's Mineral Resources; Alaska Division of Geological \& Geophysical Surveys and Alaska Department of Commerce and Economic Development, AMR 81-82.

Carnes, R.D., 1976, Active Alaskan Placer Operations, 1975; Bureau of Mines Open-File Report 98-76.

Cass, J.T., 1959, Reconnaissance Geologic Map of the Candle Quadrangle, Alaska; U.S. Geological Survey Miscellaneous Geologic Investigations Series Map I-287, 1 sheet, scale 1:250,000.

Cobb, E.H., 1972, Metallic Mineral Resources Map of the Ambler River Quadrangle, Alaska; U.S. Geological Survey Miscellaneous Field Studies Map MF-454, 1 sheet, scale 1:250,000.

Cobb, E.H., 1972, Metallic Mineral Resources Map of the Bethel Quadrangle, Alaska; U.S. Geological Survey Miscellaneous Field Studies Map MF-455, 1 sheet, scale 1:250,000.

Cobb, E.H., 1972, Metallic Mineral Resources Map of the Candle Quadrangle, Alaska; U.S. Geological Survey Miscellaneous Field Studies Map MF-389, 1 sheet, scale 1:250,000.

Cobb, E.H., 1972, Metallic Mineral Resources Map of the Circle Quadrangle, Alaska; U.S. Geological Survey Miscellaneous Field Studies Map MF-391, 1 sheet, scale 1:250,000.

Cobb, E.H., 1972, Metallic Mineral Resources Map of the Dixon Entrance Quadrangle, Alaska; U.S. Geological Survey Miscellaneous Field Studies Map MF-434, 1 sheet, scale 1:250,000.

Cobb, E.H., 1972, Metallic Mineral Resources Map of the Eagle Quadrangle, Alaska; U.S. Geological Survey Miscellaneous Field Studies Map MF-393, 1 sheet, scale 1:250,000.

Cobb, E.H., 1972, Metallic Mineral Resources Map of the Juneau Quadrangle, Alaska; U.S. Geological Survey Miscellaneous Field Studies Map MF-435, 1 sheet, scale 1:250,000.

Cobb, E.H., 1972, Metallic Mineral Resources Map of the Port Alexander Quadrangle, Alaska; U.S. Geological Survey Miscellaneous Field Studies Map MF-464, 1 sheet, scale 1:250,000.

Cobb, E.H., 1972, Metallic Mineral Resources Map of the Tanana Quadrangle, Alaska; U.S. Geological Survey Miscellaneous Field Studies Map MF-371, 1 sheet, scale 1:250,000. 
Cobb, E.H., 1972, Metallic Mineral Resources Map of the Tyonek Quadrangle, Alaska; U.S. Geological Survey Miscellaneous Field Studies Map MF-385, 1 sheet, scale 1:250,000.

Dover, J., 1997, Alaska Resource Data File-Colleen Quadrangle; U.S. Geological Survey Open-File Report 97-295, $39 \mathrm{p}$.

Eakins, G.R., 1969, Uranium in Alaska; Alaska Division of Geological \& Geophysical Surveys Geologic Report 38, 49 p., 1 sheet, scale 1:3,800,000.

Eakins, G.R., 1970, An Experiment in Geobotanical Prospecting for Uranium, Bokan Mountain Area, Southeastern Alaska; Alaska Division of Geological \& Geophysical Surveys Geologic Report 41, $51 \mathrm{p}$.

Eakins, G.R., and Forbes, R.B., 1976, Investigation of Alaska's Uranium Potential; Alaska Division of Geological \& Geophysical Surveys Geologic Report 12, 372 p., 5 sheets, scale 1:1,000,000.

Eakins, G.R., and Forbes, R.B., 1976, Investigation of Alaska's Uranium Potential; Alaska Division of Geological \& Geophysical Surveys Special Report 12, 372 p., 5 sheets, scale 1:1,000,000.

Glover, A.E., 1951, Salmon Bay-Red Bay Reconnaissance (Prince of Wales Island); Alaska Territorial Department of Mines Mineral Investigations MI-117-1, 6 p.

Glover, A.E., 1954, Tah Bay Reconnaissance (Prince of Wales Island); Alaska Territorial Department of Mines Mineral Investigations MI-121-1, 3 p.

Grybeck, D.J., 1977, Map Showing Known Mineral Deposits of the Brooks Range, Alaska; U.S. Geological Survey Open-File Report 77-166-C, 45 p., 1 sheet, scale 1:1,000,000.

Heylmun, E.B., 1999, Rare Earths at Bokan Mountain, Alaska; International California Mining Journal, January 1999, p. 44-46.

Hudson, T.L., Miller, M. L., and Peckthorn, W.J., 1977, Map Showing Metalliferous and Selected Nonmetalliferous Mineral Deposits, Seward Peninsula, Alaska; U.S. Geological Survey Open-File Report 77-796-B, 46 p., 1 sheet, scale 1:1,000,000.

Lathram, E.H., Loney, R.A., Condon, W.H., and Berg, H.C., 1959, Progress Map of the Geology of the Juneau Quadrangle, Alaska; U.S. Geological Survey Miscellaneous Geologic Investigations Series Map I-303, 1 sheet, scale 1:250,000.

MacKevett, E.M., Jr., 1959, Geology of the Ross-Adams Uranium-Thorium Deposit, Alaska; Mining and Engineering (N.Y.) 5909.

Nome Nugget, 1976, Alaska Gold Company: Almost 8,000 Ounces Mined; Nome Nugget Vol. 76, No. 10, $4 \mathrm{p}$.

Patton, W.W., Jr., and Miller, T.P., 1966, Regional Geologic Map of the Hughes Quadrangle, Alaska; U.S. Geological Survey Miscellaneous Geologic Investigations Series Map I-459, 1 sheet, scale $1: 250,000$.

Staatz, M.H., Hall, R.B., Macke, D.L., Armbrustmacher, T.J., and Brownfield, I.K., 1980, Thorium Resources of Selected Regions in the United States; U.S. Geological Survey Circular 824, 32 p.

Thomas, B., 1948, Nixon Fork Mining District; Alaska Territorial Department of Mines Miscellaneous Report MR-65-2, 43 p. 
Thompson, T.B., 1987, Geology and Uranium-Thorium Mineral Deposits of the Bokan Mountain Granite Complex, Southeastern Alaska; Ore Geology Reviews 3 (1988), p. 193-210.

Thorne, R.L., and Wright, W.S., 1948, Sampling Methods and Results at the Sullivan Creek Tin Placer Deposits, Manley Hot Springs, Tofty, Alaska; Bureau of Mines Report of Investigations 4346, 8 p.

U.S. Bureau of Mines, 1995, Spatial Data Extracted from the Minerals Availability System/ Mineral Industry Location System (MAS/MILS); U.S. Bureau of Mines Special Publication 12-95, CDROM.

Wallace Miner, 1970, Dawn Uses Option for Sale of Uranium Oxide; Wallace Miner.

Warner, J.D., 1989, Columbium-, Rare-Earth-Element-, and Thorium-Bearing Veins Near Salmon Bay, Southeastern Alaska; U.S. Bureau of Mines Open-File Report 06-89, 25 p.

Williams, J.A., 1955, Carol Anne Property (Kendrick Bay); Alaska Territorial Department of Mines Prospect Evaluation PE-121-7, 5 p.

Williams, J.A., 1955, I \& L Property (Kendrick Bay); Alaska Territorial Department of Mines Prospect Evaluation PE-121-5, 8 p.

\section{Titanium}

Barker, J.C., Still, J.C., Mowatt, T.C., and Mulligan, J.J., 1981, Critical and Strategic Minerals in Alaska: Cobalt, the Platinum-Group Metals, and Chromite; Bureau of Mines Information Circular 8869, 8 p., 1 sheet, scale 1:250,000.

Berg, H.C., and Cobb, E.H., 1967, Metalliferous Lode Deposits of Alaska; U.S. Geological Survey Bulletin $1246,254 \mathrm{p}$.

Berg, H.C., Decker, J.E., and Abramson, B.S., 1981, Metallic Mineral Deposits of Southeastern Alaska; U.S. Geological Survey Open-File Report 81-122, 145 p., 1 sheet, scale 1:1,000,000.

Brew, D.A., Johnson, B.R., Grybeck, D.J., Griscom, A., and Barnes, D.F., 1978, Mineral Resources of the Glacier Bay National Wilderness Study Area, Alaska; U.S. Geological Survey Open-File Report 78-494, 670 p., 6 sheets, scale 1:125,000.

Brosge, W.P., and Reiser, H.N., 1960, Progress Map of the Geology of the Wiseman Quadrangle, Alaska; U.S. Geological Survey Open-File Report 60-19, 3 sheets, scale 1:250,000.

Cobb, E.H., 1972, Metallic Mineral Resources Map of the Cold Bay Quadrangle, Alaska; U.S. Geological Survey Miscellaneous Field Studies Map MF-441, 1 sheet, scale 1:250,000.

Cobb, E.H., 1972, Metallic Mineral Resources Map of the Dillingham Quadrangle, Alaska; U.S. Geological Survey Miscellaneous Field Studies Map MF-375, 1 sheet, scale 1:250,000.

Cobb, E.H., 1972, Metallic Mineral Resources Map of the Livengood Quadrangle, Alaska; U.S. Geological Survey Miscellaneous Field Studies Map MF-413, 1 sheet, scale 1:250,000.

Cobb, E.H., 1972, Metallic Mineral Resources Map of the Mount Fairweather Quadrangle, Alaska; U.S. Geological Survey Miscellaneous Field Studies Map MF-436, 1 sheet, scale 1:250,000.

Cobb, E.H., 1972, Metallic Mineral Resources Map of the Skagway Quadrangle, Alaska; U.S. Geological Survey Miscellaneous Field Studies Map MF-424, 1 sheet, scale 1:250,000. 
Cobb, E.H., 1972, Metallic Mineral Resources Map of the Sumdum Quadrangle, Alaska; U.S. Geological Survey Miscellaneous Field Studies Map MF-425, 1 sheet, scale 1:250,000.

Cobb, E.H., 1972, Metallic Mineral Resources Map of the Yakutat Quadrangle, Alaska; U.S. Geological Survey Miscellaneous Field Studies Map MF-408, 1 sheet, scale 1:250,000.

Cobb, E.H., 1973, Placer Deposits of Alaska; U.S. Geological Survey Bulletin 1374, 213 p., 1 sheet.

Detterman, R.L., and Cobb, E.H., 1972, Metallic Mineral Resources Map of the Iliamna Quadrangle, Alaska; U.S. Geological Survey Miscellaneous Field Studies Map MF-364, 1 sheet, scale $1: 250,000$.

Eberlein, G.D., Chapman, R.M., Foster, H.L., and Gassaway, J.S., 1977, Map and Table Describing Known Metalliferous and Selected Nonmetalliferous Mineral Deposits in Central Alaska; U.S. Geological Survey Open-File Report 77-168-D, 131 p., 1 sheet, scale 1:1,000,000.

Foster, R.L., and Chapman, R.M., 1967, Locations and Descriptions of Lode Prospects in the Livengood Area, East-Central Alaska; U.S. Geological Survey Open-File Report 67-91, 7 p.

Humble Oil and Refining Co., 1959, Kemuk Mountain Iron Ore Prospect; Alaska Territorial Department of Mines Miscellaneous Report MR-102-1, 12 p., 4 maps.

Kaufman, A., 1958, Southeastern Alaska's Mineral Industry; Bureau of Mines Information Circular 7844, $37 \mathrm{p}$.

MacKevett, E.M., Jr., and Holloway, C.D., 1977, Map Showing Metalliferous Mineral Deposits in the Western Part of Southern Alaska; U.S. Geological Survey Open-File Report 77-169-F, 39 p., 1 sheet, scale 1:1,000,000.

MacKevett, E.M., Jr., and Holloway, C.D., 1977, Map Summarizing Metalliferous and Selected Nonmetalliferous Mineral Deposits in the Eastern Part of Southern Alaska; U.S. Geological Survey Open-File Report 77-169-A, 99 p., 1 sheet, scale 1:1,000,000.

Mayfield, C.F., and Grybeck, D., 1978, Mineral Occurrences and Resources Map of the Ambler River Quadrangle, Alaska; U.S. Geological Survey Open-File Map 78-120 I, 1 sheet, scale 1:250,000.

Miller, D.L., 1961, Geology of the Yakutat District, Gulf of Alaska Tertiary Province, Alaska; U.S. Geological Survey Open-File Report 61-103, 2 sheets, scale 1:96,000.

Nelson, S., 1997, Alaska Resource Data File-Ambler River Quadrangle; U.S. Geological Survey Open-File Report 97-856, $98 \mathrm{p}$.

Robertson, E.C., 1956, Magnetite Deposits Near Klukwan and Haines, Alaska; U.S. Geological Survey Open-File Report 56-101, 37 p., 11 sheets, scales 1:9,000, 1:3,168,000, 1:4,500, 1:600, and $1: 18,000$.

Rossman, D.L., 1957, Ilmenite-Bearing Beach Sands Near Lituya Bay, Alaska; U.S. Geological Survey Open-File Report 57-98, 11 p., 1 sheet, scale 1:125,000.

Still, J.C., 1983, Copper, Gold, Platinum, and Palladium Sample Results From the Klukwan Mafic/ Ultramafic Complex, Southeast Alaska; Bureau of Mines Open-File Report 21-84, 53 p.

Thomas, B.I., and Berryhill, R.V., 1962, Reconnaissance Studies of Alaskan Beach Sands, Eastern Gulf of Alaska; Bureau of Mines Report of Investigations 5986, 40 p. 
Thorne, R.L., and Wells, R.R., 1956, Studies of the Snettisham Magnetite Deposit, Southeastern Alaska; Bureau of Mines Report of Investigations 5195, 41 p.

U.S. Bureau of Mines, 1985, Unpublished data, 1970-1985.

Wells, R.R., and Thorne, R.L., 1953, Concentration of Klukwan, Alaska, Magnetite Ore; Bureau of Mines Report of Investigations 4984, 15 p.

\section{Uranium}

Alaska Department of Revenue, 1985, Mine License Application.

Alaska Economic Report (Anchorage), 1979, Alaska Mineral Exploration Increasing, But Land Uncertainties Cloud Future; Alaska Economic Report May 15, 1979, 8 p.

Barker, J.C., 1981, Mineral Investigations in the Porcupine River Drainage, Alaska; U.S. Bureau of Mines Open-File Report 27-81, 189 p.

Barker, J.C., and Clautice, K.H., 1978, Mineral Reconnaissance of the Porcupine River Region: A Summary Report; U.S. Bureau of Mines Open File Report 87-78, 20 p.

Barker, J.C., and Warner, J.D., 1988, USBM Inventories Alaskan Rare Earths Deposits; Engineering \& Mining Journal, v.189, no.2, p. 42-43.

Berg, H.C., 1999, Alaska Resource Data File-Prince Rupert Quadrangle; U.S. Geological Survey Open-File Report 99-306, $16 \mathrm{p}$.

Berg, H.C., and Cobb, E.H.,1967, Metalliferous Lode Deposits of Alaska; U.S. Geological Survey Bulletin $1246,254 \mathrm{p}$.

Berg, H.C., Decker, J.E., and Abramson, B.S., 1981, Metallic Mineral Deposits of Southeastern Alaska; U.S. Geological Survey Open-File Report 81-122, 145 p., 1 sheet, scale 1:1,000,000.

Brew, D.A., Grybeck, D.J., Johnson, B.R., and Jachens, R.C., 1977, Mineral Resources of the Tracy ArmFords Terror Wilderness Study Area and Vicinity, Alaska; U.S. Geological Survey Open-File Report 77-649, 467 p., 4 sheets, scale 1:125,000.

Brosge', W.R., and Reiser, H.N., 1968, Geochemical Maps of Granitic Rocks, Coleen and Table Mountain Quadrangles, Alaska; U.S. Geological Survey Open-File Report 323, 1 sheet, scale 1:250.000.

Bundtzen, T.K., Eakins, G.R., and Conwell, C.N., 1982, Review of Alaska's Mineral Resources; Alaska Division of Geological \& Geophysical Surveys and Alaska Department of Commerce and Economic Development, AMR 81-82.

Campbell, L.J., 1995, Alaska's Mineral Industry Today; Alaska Geographic, v.22, no.3, p. 31-65.

Cass, J.T., 1959, Reconnaissance Geologic Map of the Candle Quadrangle, Alaska; U.S. Geological Survey Miscellaneous Geologic Investigations Series Map I-287, 1 sheet, scale 1:250,000.

Clark, A.L., and Cobb, E.H., 1972, Metallic Mineral Resources Map of the Talkeetna Quadrangle, Alaska; U.S. Geological Survey Miscellaneous Field Studies Map MF-369, 1 sheet, scale 1:250,000.

Cobb, E.H., 1972, Metallic Mineral Resources Map of the Bendeleben Quadrangle, Alaska; U.S. Geological Survey Miscellaneous Field Studies Map MF-417, 1 sheet, scale 1:250,000. 
Cobb, E.H., 1972, Metallic Mineral Resources Map of the Bering Glacier Quadrangle, Alaska; U.S. Geological Survey Miscellaneous Field Studies Map MF-373, 1 sheet, scale 1:250,000.

Cobb, E.H., 1972, Metallic Mineral Resources Map of the Bethel Quadrangle, Alaska; U.S. Geological Survey Miscellaneous Field Studies Map MF-455, 1 sheet, scale 1:250,000.

Cobb, E.H., 1972, Metallic Mineral Resources Map of the Bettles Quadrangle, Alaska; U.S. Geological Survey Miscellaneous Field Studies Map MF-387, 1 sheet, scale 1:250,000.

Cobb, E.H., 1972, Metallic Mineral Resources Map of the Candle Quadrangle, Alaska; U.S. Geological Survey Miscellaneous Field Studies Map MF-389, 1 sheet, scale 1:250,000.

Cobb, E.H., 1972, Metallic Mineral Resources Map of the Circle Quadrangle, Alaska; U.S. Geological Survey Miscellaneous Field Studies Map MF-391, 1 sheet, scale 1:250,000.

Cobb, E.H., 1972, Metallic Mineral Resources Map of the Coleen Quadrangle, Alaska; U.S. Geological Survey Miscellaneous Field Studies Map MF-403, 1 sheet, scale 1:250,000.

Cobb, E.H., 1972, Metallic Mineral Resources Map of the Dixon Entrance Quadrangle, Alaska; U.S. Geological Survey Miscellaneous Field Studies Map MF-434, 1 sheet, scale 1:250,000.

Cobb, E.H., 1972, Metallic Mineral Resources Map of the Eagle Quadrangle, Alaska; U.S. Geological Survey Miscellaneous Field Studies Map MF-393, 1 sheet, scale 1:250,000.

Cobb, E.H., 1972, Metallic Mineral Resources Map of the Iditarod Quadrangle, Alaska; U.S. Geological Survey Miscellaneous Field Studies Map MF-363, 1 sheet, scale 1:250,000.

Cobb, E.H., 1972, Metallic Mineral Resources Map of the Iliamna Quadrangle, Alaska; U.S. Geological Survey Miscellaneous Field Studies Map MF-364, 1 sheet, scale 1:250,000.

Cobb, E.H., 1972, Metallic Mineral Resources Map of the Juneau Quadrangle, Alaska; U.S. Geological Survey Miscellaneous Field Studies Map MF-435, 1 sheet, scale 1:250,000.

Cobb, E.H., 1972, Metallic Mineral Resources Map of the Livengood Quadrangle, Alaska; U.S. Geological Survey Miscellaneous Field Studies Map MF-413, 1 sheet, scale 1:250,000.

Cobb, E.H., 1972, Metallic Mineral Resources Map of the Petersburg Quadrangle, Alaska; U.S. Geological Survey Miscellaneous Field Studies Map MF-415, 1 sheet, scale 1:250,000.

Cobb, E.H., 1972, Metallic Mineral Resources Map of the Prince Rupert Quadrangle, Alaska; U.S. Geological Survey Miscellaneous Field Studies Map MF-437, 1 sheet, scale 1:250,000.

Cobb, E.H., 1972, Metallic Mineral Resources Map of the Ruby Quadrangle, Alaska; U.S. Geological Survey Miscellaneous Field Studies Map MF-405, 1 sheet, scale 1:250,000.

Cobb, E.H., 1972, Metallic Mineral Resources Map of the Skagway Quadrangle, Alaska; U.S. Geological Survey Miscellaneous Field Studies Map MF-424, 1 sheet, scale 1:250,000.

Cobb, E.H., 1972, Metallic Mineral Resources Map of the Solomon Quadrangle, Alaska; U.S. Geological Survey Miscellaneous Field Studies Map MF-445, 1 sheet, scale 1:250,000.

Cobb, E.H., 1972, Metallic Mineral Resources Map of the Tanana Quadrangle, Alaska; U.S. Geological Survey Miscellaneous Field Studies Map MF-371, 1 sheet, scale 1:250,000.

Cobb, E.H., 1972, Metallic Mineral Resources Map of the Tyonek Quadrangle, Alaska; U.S. Geological Survey Miscellaneous Field Studies Map MF-385, 1 sheet, scale 1:250,000. 
Cobb, E.H., 1973, Placer Deposits of Alaska; U.S. Geological Survey Bulletin 1374, 213 p., 1 sheet.

Cobb, E.H., 1975, Summary of References to Mineral Occurrences (Other Than Mineral Fuels and Construction Materials) in the Bendeleben Quadrangle, Alaska; U.S. Geological Survey Open-File Report 75-429, 123 p.

Cobb, E.H., 1978, Summary of References to Mineral Occurrences (Other Than Mineral Fuels and Construction Materials) in the Solomon Quadrangle, Alaska; U.S. Geological Survey Open-File Report 78-181, 185 p.

Cobb, E.H., and Elliott, R.L., 1980, Summary of Data on and Lists of References to Metallic and Selected Nonmetallic Mineral Deposits in the Ketchikan and Prince Rupert Quadrangles, Alaska; U.S. Geological Survey Open-File Report 80-1053, 156 p.

Cobb, E.H., and Sainsbury, C.L., 1972, Metallic Mineral Resources Map of the Teller Quadrangle, Alaska; U.S. Geological Survey Miscellaneous Field Studies Map MF-426, 1 sheet, scale 1:250,000.

Cobb, E.H., Mayfield, C.F., Brosge, W.P., 1981, Summaries of Data on and Lists of References to Metallic and Selected Non-Metallic Mineral Occurrences in Eleven Quadrangles in Northern Alaska-Summaries of Data to January 1, 1981; U.S. Geological Survey Open-File Report 81-767, 40 p.

Dover, J., 1997, Alaska Resource Data File-Colleen Quadrangle; U.S. Geological Survey Open-File Report 97-295, $39 \mathrm{p}$.

Dover, J.H., 1997, Alaska Resource Date File-Howard Pass Quadrangle; U.S. Geological Survey Open-File Report 97-296, 47 p.

Eakins, G.R., 1969, Uranium in Alaska; Alaska Division of Geological \& Geophysical Surveys Geologic Report 38, 49 p., 1 sheets, scale 1:3,800,000.

Eakins, G.R., 1970, An Experiment in Geobotanical Prospecting for Uranium, Bokan Mountain Area, Southeastern Alaska; Alaska Division of Geological \& Geophysical Surveys Geologic Report 41, $51 \mathrm{p}$.

Eakins, G.R., 1975, Uranium Investigations in Southeastern Alaska; Alaska Division of Geological \& Geophysical Surveys Geologic Report 44, 62 p.

Eakins, G.R., and Forbes R.B., 1976, Investigation of Alaska's Uranium Potential; Alaska Division of Geological \& Geophysical Surveys Special Report 12, 372 p., 5 sheets, scale 1:1,000,000.

Foster, R.L., and Chapman, R.M., 1967, Locations and Descriptions of Lode Prospects in the Livengood Area, East-Central Alaska; U.S. Geological Survey Open-File Report 67-91, 6 p.

Glover, A.E., 1951, Salmon Bay-Red Bay Reconnaissance (Prince of Wales Island); Alaska Territorial Department of Mines Mineral Investigations MI-117-1, 6 p.

Glover, A.E., 1951, Union Bay Reconnaissance (Cleveland Peninsula); Alaska Territorial Department of Mines Mineral Investigations MI-119-2, 4 p.

Gray, J.E., Sanzolone, R.F., 1996, Environmental Studies of Mineral Deposits in Alaska; U.S. Geological Survey Bulletin 2156, $39 \mathrm{p}$.

Grybeck, D.J., 1977, Map Showing Known Mineral Deposits of the Brooks Range, Alaska; U.S. Geological Survey Open-File Report 77-166-C, 45 p., 1 sheet, scale 1:1,000,000.

Harben, P.W., 1984, Geology of the Nonmetallics; Metal Bulletin Inc., New York, 392 p. 
Heylmun, E.B., 1999, Rare Earths at Bokan Mountain, Alaska; International California Mining Journal, January 1999, p. 44-46.

Hoare, J.M., and Cobb, E.H., 1972, Metallic Mineral Resources Map of the Russian Mission Quadrangle, Alaska; U.S. Geological Survey Miscellaneous Field Studies Map MF-444, 1 sheet, scale $1: 250,000$.

Hoare, J.M., and Coonrad, W.L., 1959, Geology of the Russian Mission Quadrangle, Alaska; U.S. Geological Survey Miscellaneous Geologic Investigations Series Map I-292, 1 sheet, scale $1: 250,000$.

Hudson, T.L., Miller, M.L., and Peckthorn, W.J., 1977, Map Showing Metalliferous and Selected Nonmetalliferous Mineral Deposits, Seward Peninsula, Alaska; U.S. Geological Survey Open-File Report 77-796-B, 46 p., 1 sheet, scale 1:1,000,000.

Jansons, U., and Baggs, D.W., 1980, Mineral Investigations of the Misheguk Mountains and Howard Pass Quadrangles, National Petroleum Reserve-Alaska; U.S. Bureau of Mines Open-File Report 38-80, $76 \mathrm{p}$.

Jones, D.A., 1953, Foster Lead-Silver Prospect (Seward Peninsula); Alaska Territorial Department of Mines Prospect Evaluation PE-44-1, 14 p., 3 maps.

Kelley, K.D., 1997, Alaska Resource Data File-Chandler Lake Quadrangle; U.S. Geological Survey OpenFile Report 97-265, 24 p.

Kelley, K.D., 1997, Alaska Resource Data File-Killik River Quadrangle; U.S. Geological Survey Open-File Report 97-266, 20 p.

Killeen, P.L., and Ordway, R.J., 1955, Radioactivity Investigations at Ear Mountain, Seward Peninsula, Alaska, 1945; U.S. Geological Survey Bulletin 1024-C, 35 p.

Kurtak, J.M., Hicks, R.W., Werdon, M.B., Meyer, M.P., and Mull, C.G., 1995, Mineral Investigations in the Colville Mining District and Southern National Petroleum Reserve in Alaska; Bureau of Mines Open-File Report 8-95, 217 p., 1 sheet, scale 1:250,000.

Lathram, E.H., Loney, R.A., Condon, W.H., and Berg, H.C., 1959, Progress Map of the Geology of the Juneau Quadrangle, Alaska; U.S. Geological Survey Miscellaneous Geologic Investigations Series Map I-303, 1 sheet, scale 1:250,000.

LeFond, S.J., ed., 1983, Industrial Minerals and Rocks; Society of Mining Engineers, 2 vols, 1433 p.

MacKevett, E.M., 1963, Geology and Ore Deposits of the Bokan Mountain Uranium-Thorium Area, Southeastern Alaska; U.S. Geological Survey Bulletin 1154, 125 p.

MacKevett, E.M., Jr., 1959, Geology of the Ross-Adams Uranium-Thorium Deposit, Alaska; Mining and Engineeering (N.Y.) 5909.

MacKevett, E.M., Jr., and Holloway, C.D., 1977, Map Summarizing Metalliferous and Selected Nonmetalliferous Mineral Deposits in the Eastern Part of Southern Alaska; U.S. Geological Survey Open-File Report 77-169-A, 39 p., 1 sheet, scale 1:1,000,000.

Mattson, M.J., 1978, Production Statistics of Cache Creek, Yentna District, Talkeetna Quadrangle; Letter to Thad E. Sandford. 
Mayfield, C.F., and Grybeck, D., 1978, Mineral Occurrences and Resources Map of the Ambler River Quadrangle, Alaska; U.S. Geological Survey Open-File Map 78-120 I, 1 sheet, scale 1:250,000.

Meyer, M.P., 1994, Analytical Results from U.S. Bureau of Mines Investigations in the Colville Mining District, Alaska; U.S. Bureau of Mines Open-File Report 34-94, 137 p.

Mulligan, J.J., 1959, Tin Placer and Lode Investigations, Ear Mountain Area, Seward Peninsula, Alaska; Bureau of Mines Report of Investigations 5493, 53 p.

Nelson, S., 1997, Alaska Resource Data File-Ambler River Quadrangle; U.S. Geological Survey Open-File Report 97-856, 98 p.

O'Conner, W.K., 1992, Bureau of Mines Research Center, Salt Lake City, Utah; Written Communication, November 1992.

Patton, W.W., Jr., and Matzko, J.J., 1959, Phosphate Deposits in Northern Alaska; U.S. Geological Survey Professional Paper 302-A, 17 p.

Patton, W.W., Jr., and Tailleur, I.L., 1964, Geology of the Upper Killik-Itkillik Region, Alaska; U.S. Geological Survey Professional Paper 303-G, 90 p.

Perkins, W, Jr., 1994, Simplot Co., Afton, Wyoming; Written Communication, April 1994.

Reed, B.L., Nelson, S.W., Curtin, G.C., and Singer, D.A., 1978, Mineral Resources Map of the Talkeetna Quadrangle, Alaska; U.S. Geological Survey Miscellaneous Field Studies Map MF-870-D, 1 sheet, scale 1:250,000.

Sandvik, P.O., 1956, Mineral Investigation of a Radioactive Anomaly in the Candle Area; Alaska Territorial Department of Mines Mineral Investigations MI-44-2, 6 p., 1 map.

Staatz, M.H., Hall, R.B., Macke, D.L., Armbrustmacher, T.J., and Brownfield, I.K., 1980, Thorium Resources of Selected Regions in the United States; U.S. Geological Survey Circular 824, 32 p.

Summers, C.A., 1992, Mineralogy of the Ivotuk Hills Phosphate Occurrence, Colville Mining District, Alaska; U.S. Bureau of Mines, Unpublished Report, 6 p.

Tailleur, I.L., Pessel, G.H., Brosge', W.P., and Mayfield, C.F., 1976, Informal Cooperation Between U.S. Geological Survey and State of Alaska, Division of Geological and Geophysical Surveys, in the Brooks Range, in Cobb, E.H., ed., The United States Geological Survey in Alaska: Accomplishments During 1975; U.S. Geological Survey Circular 733, p. 29.

Thompson, T.B., 1987, Geology and Uranium-Thorium Mineral Deposits of the Bokan Mountain Granite Complex, Southeastern Alaska; Ore Geology Reviews 3 (1988), p. 193-210.

Tysdal, R.G., 1979, Mines, Prospects, and Occurrences Map of the Seward and Blying Sound Quadrangles, Alaska; U.S. Geological Survey Miscellaneous Field Studies Map MF-880-A, 2 sheets, scale $1: 250,000$.

U.S. Bureau of Mines, 1973, Alaska 1:250,000 Scale Quadrangle Map Overlays Showing Mineral Deposit Locations, Principal Minerals, and Number and Type of Claims; Bureau of Mines Open-File Report 20-73, $41 \mathrm{p}$.

U.S. Bureau of Mines, 1995, Spatial Data Extracted from the Minerals Availability System/ Mineral Industry Location System (MAS/MILS); U.S. Bureau of Mines Special Publication 12-95, CDROM. 
U.S. Department of Labor, Mine Safety and Health Administration, 1985, Mine Safety and Health Examinations, 1975-1985.

U.S. Geological Survey, 1990, Generalized Geologic Map of the Chandler Lake Quadrangle, North-Central Alaska; U.S. Geological Survey Miscellaneous Field Studies Map MF-2144-A.

U.S. Geological Survey, 1992, U.S. Geological Survey Emeritus; Written Communication, October 1992.

Vandel, J., 1993, Bureau of Mines Salt Lake City Research Center; Written Communication, December 1993 and May 1994.

Wallace Miner, 1970, Dawn Uses Option for Sale of Uranium Oxide; Wallace Miner.

Wedow, H., Jr., and others, 1953, Preliminary Summary of Reconnaissance for Uranium and Thorium in Alaska, 1952; U.S. Geological Survey Circular 248, 15 p., 1 sheet, scale 1:11,088,000.

Wedow, H., Jr., White, M.G., and Moxham, R.M., 1952, Interim Report on an Appraisal of the Uranium Possibilities of Alaska; U.S. Geological Survey Open-File Report 51, 123 p.

White, M.G., 1952, Reconnaissance for Radioactive Deposits Along the Upper Porcupine and Lower Coleen Rivers, Northeastern Alaska; U.S. Geological Survey Circular 185, 13 p.

Williams, J.A., 1951, Radiometric Investigations, Connel Property (28 Mile); Alaska Territorial Department of Mines Prospect Evaluation PE-51-1, 10 p.

Williams, J.A., 1955, BBH Property (Endicott Arm); Alaska Territorial Department of Mines Prospect Evaluation PE-115-7, 7 p., 1 sheet, scale 1:480.

Williams, J.A., 1955, Carol Anne Property (Kendrick Bay); Alaska Territorial Department of Mines Prospect Evaluation PE-121-7, 5 p.

Williams, J.A., 1955, I \& L Property (Kendrick Bay); Alaska Territorial Department of Mines Prospect Evaluation PE-121-5, 8 p.

Williams, J.A., 1955, Lazo Property (Moira Sound); Alaska Territorial Department of Mines Prospect Evaluation PE-121-6, 3 p.

Williams, J.A., 1956, Alibill No. 2 Claim (Alfred C. Wolk Property); Alaska Territorial Department of Mines Prospect Evaluation PE-109-3, 8 p.

Williams, J.A., 1956, Itinerary Report - Skagway and Haines, April 18 to 20; Alaska Division of Geological \& Geophysical Surveys Itinerary Report IR-195-50, 2 p.

\section{Vanadium}

Barker, J.C., Still, J.C., Mowatt, T.C., and Mulligan, J.J., 1981, Critical and Strategic Minerals in Alaska: Cobalt, the Platinum-Group Metals, and Chromite; Bureau of Mines Information Circular 8869, 8 p., 1 sheet, scale 1:250,000.

Barker, J.C., Still, J.C., Mowatt, T.C., and Mulligan, J.J., 1981, Critical and Strategic Minerals in Alaska: Cobalt, the Platinum-Group Metals, and Chromite; Bureau of Mines Information Circular 8869, 8 p., 1 sheet, scale 1:250,000. 
Brosge, W.P., and Reiser, H.N., 1964, Geologic Map and Section of the Chandalar Quadrangle, Alaska; U.S. Geological Survey Miscellaneous Geologic Investigations Series Map I-375, 1 sheet, scale $1: 250,000$.

Brosge, W.P., and Reiser, H.N., 1964, Geologic Map and Section of the Chandalar Quadrangle, Alaska; U.S. Geological Survey Miscellaneous Geologic Investigations Series Map I-375, 1 sheet, scale $1: 250,000$.

Cobb, E.H., 1972, Metallic Mineral Resources Map of the Chandalar Quadrangle, Alaska; U.S. Geological Survey Miscellaneous Field Studies Map MF-457, 1 sheet, scale 1:250,000.

Cobb, E.H., 1972, Metallic Mineral Resources Map of the Sumdum Quadrangle, Alaska; U.S. Geological Survey Miscellaneous Field Studies Map MF-425, 1 sheet, scale 1:250,000.

Cobb, E.H., 1973, Metallic Mineral Resources Map of the Craig Quadrangle, Alaska; U.S. Geological Survey Miscellaneous Field Studies Map MF-433, 1 sheet, scale 1:250,000.

Cobb, E.H., 1975, Summary of References to Mineral Occurrences (other than mineral fuels and construction materials) in Northern Alaska; U.S. Geological Survey Open-File Report 75-628, 106 p.

Cobb, E.H., Mayfield, C.F., Brosge, W.P., 1981, Summaries of Data on and Lists of References to Metallic and Selected Non-Metallic Mineral Occurrences in Eleven Quadrangles in Northern Alaska-Summaries of Data to January 1, 1981; U.S. Geological Survey Open-File Report 81-767, 40 p.

Dover, J.H., 1997, Alaska Resource Date File-Howard Pass Quadrangle; U.S. Geological Survey Open-File Report 97-296, 47 p.

Goldberg, I., Hammerbeck, E.C.I., Labuschagne, L.S., and Rossouw, C., 1992, International Strategic Minerals Inventory Summary Report-Vanadium; U.S. Geological Survey Circular 930-K, 45 p.

Grybeck, D.J., 1977, Map Showing Known Mineral Deposits of the Brooks Range, Alaska; U.S. Geological Survey Open-File Report 77-166-C, 45 p., 1 sheet, scale 1:1,000,000.

Harben, P.W., 1984, Geology of the Nonmetallics; Metal Bulletin Inc., New York, 392 p.

Heiner, L.E., and Wolff, E.N., 1968, Mineral Resources of Northern Alaska, Final Report Submitted to the North Commission; Mineral Industry Research Laboratory, University of Alaska, Report 16, 306 p., 3 sheets, scales 1:1,000,000 and 1:5,000,000.

Holdsworth, P.R., 1954, Investigation of Claim Staking (Union Bay Area); Alaska Territorial Department of Mines Prospect Evaluation PE-119-23.

Howard, A.L., 1935, Rush and Brown-Salt Chuck (Alaska Gold and Metals Co., Kasaan Bay); Alaska Territorial Department of Mines Miscellaneous Report MR-119-2, 8 p.

Howard, A.L., 1935, Salt Chuck Mine (Alaska Gold and Metals Co., Kasaan Bay); Alaska Territorial Department of Mines Miscellaneous Report MR-119-2A, 14 p., 1 map.

Kaufman, A., 1958, Southeastern Alaska's Mineral Industry; Bureau of Mines Information Circular 7844, $37 \mathrm{p}$.

Kelley, J.S., 1982, Phosphate and Whole Rock Chemical Analyses from Upper Paleozoic and Lower Mexozoic Strata in the Chandler Lake and Killik River Quadrangles, Alaska; U.S. Geological Survey Unpublished Report. 
Kelley, K.D., 1997, Alaska Resource Data File-Chandler Lake Quadrangle; U.S. Geological Survey OpenFile Report 97-265, 24 p.

Kurtak, J.M., Hicks, R.W., Werdon, M.B., Meyer, M.P., and Mull, C.G., 1995, Mineral Investigations in the Colville Mining District and Southern National Petroleum Reserve in Alaska; Bureau of Mines Open-File Report 8-95, 217 p., 1 sheet, scale 1:250,000.

LeFond, S.J., ed., 1983, Industrial Minerals and Rocks; Society of Mining Engineers, 2 vol., 1433 p.

Mayfield, C.F., and Grybeck, D., 1978, Mineral Occurrences and Resources Map of the Ambler River Quadrangle, Alaska; U.S. Geological Survey Open-File Map 78-120 I, 1 sheet, scale 1:250,000.

Meyer, M.P., 1994, Analytical Results from U.S. Bureau of Mines Investigations in the Colville Mining District, Alaska; U.S. Bureau of Mines Open-File Report 34-94, 137 p.

Nelson, S., 1997, Alaska Resource Data File-Ambler River Quadrangle; U.S. Geological Survey Open-File Report 97-856, 98 p.

O'Conner, W.K., 1992, BuMines Research Center, Salt Lake City, Utah; Written Communication, November 1992.

Patton, W.W., Jr., and Matzko, J.J., 1959, Phosphate Deposits in Northern Alaska; U.S. Geological Survey Professional Paper 302-A, 17 p.

Patton, W.W., Jr., and Tailleur, I.L., 1964, Geology of the Upper Killik-Itkillik Region, Alaska; U.S. Geological Survey Professional Paper 303-G, 90 p.

Perkins, W, Jr., 1994, Simplot Co., Afton, Wyoming; Written Communication, April 1994.

Pillmore, C.L., and McQueen, K., 1956, Map of Salt Chuck Area, Prince of Wales Island, Alaska, Showing Linear Features as Seen on Aerial Photographs; U.S. Geological Survey Miscellaneous Geologic Investigations Series Map I-230, 1 sheet, scale 1:12,000.

Ruckmick, J.C., and Noble, J.A., 1959, Origin of the Ultramafic Complex at Union Bay, Southeastern Alaska; Geological Society of America Bulletin 5908, 36 p.

Schmidt, J.M., and Werdon, M.B., 1993, Clastic-hosted Stratiform, Vein/ Breccia and Disseminated Zn-PbAg Deposits of the Northwestern Brooks Range, Alaska: Are They Different Expressions of Dewatering of the Same Source Basin? [abs.]; Geological Society of America, Abstracts with Programs, v. 24, p. 143.

Schmidt, Jeanine M., 1997, Shale-Hosted Zn-Pb-Ag and Barite Deposits of Alaska; Economic Geology Monograph 9, $31 \mathrm{p}$.

Shepard, J.G., 1926, Ketchikan District Properties; Alaska Territorial Department of Mines Miscellaneous Report MR-191-1A, 18 p.

Summers, C.A., 1992, Mineralogy of the Ivotuk Hills Phosphate Occurrence, Colville Mining District, Alaska; U.S. Bureau of Mines, Unpublished Report, 6 p.

Thorne, R.L., and Wells, R.R., 1956, Studies of the Snettisham Magnetite Deposit, Southeastern Alaska; Bureau of Mines Report of Investigations 5195, 41 p.

U.S. Bureau of Mines, 1945, Salt Chuck Mine, Kasaan Peninsula, Prince of Wales Island, Southeastern Alaska--Copper, Palladium; Bureau of Mines War Minerals Report 423, 17 p. 
U.S. Bureau of Mines, 1995, Spatial Data Extracted from the Minerals Availability System/ Mineral Industry Location System (MAS/MILS); U.S. Bureau of Mines Special Publication 12-95, CDROM.

U.S. Geological Survey, 1990, Generalized Geologic Map of the Chandler Lake Quadrangle, North-Central Alaska; U.S. Geological Survey Miscellaneous Field Studies Map MF-2144-A.

U.S. Geological Survey, 1992, U.S. Geological Survey Emeritus; Written Communication, October 1992.

Vandel, J., 1993, Bureau of Mines Salt Lake City Research Center; Written Communication, December 1993 and May 1994.

Wedow, H., Jr., White, M.G., and Moxham, R.M., 1952, Interim Report on an Appraisal of the Uranium Possibilities of Alaska; U.S. Geological Survey Open-File Report 51, 123 p.

\section{NONMETALLIC MINERALS}

\section{Asbestos}

Anderson, E., 1945, Asbestos and Jade Occurrences in the Kobuk River Region, Alaska; Alaska Territorial Department of Miners Pamphlet 3-R, 48 p.

Anderson, E., 1947, Mineral Occurrences Other Than Gold Deposits in Northwest Alaska; Alaska Territorial Department of Mines Pamphlet 5-R, 48 p.

Barker, J.C., Still, J.C., Mowatt, T.C., and Mulligan, J.J., 1981, Critical and Strategic Minerals in Alaska: Cobalt, the Platinum-Group Metals, and Chromite; Bureau of Mines Information Circular 8869, 8 p., 1 sheet, scale 1:250,000.

Berg, H.C., 1972, Geologic Map of Annette Island, Alaska; U.S. Geological Survey Miscellaneous Geological Investigations Series Map I-684, 1 sheet, scale 1:63,360.

Bottge, R.G., 1975, Comparative Asbestos Mining and Processing Costs-Alaska Versus Yukon Territory; Bureau of Mines Information Circular 8672, $33 \mathrm{p}$.

Bundtzen, T.K., and Smith, T.E., 1982, Alaska's Industrial Minerals; Alaska Geographic 9, p. 64-73.

Bundtzen, T.K., Eakins, G.R., and Conwell, C.N., 1982, Review of Alaska's Mineral Resources; Alaska Division of Geological \& Geophysical Surveys and Alaska Department of Commerce and Economic Development, AMR 81-82.

Cobb, E.H., 1972, Metallic Mineral Resources Map of the Ambler River Quadrangle, Alaska; U.S. Geological Survey Miscellaneous Field Studies Map MF-454, 1 sheet, scale 1:250,000.

Cobb, E.H., 1972, Metallic Mineral Resources Map of the Ketchikan Quadrangle, Alaska; U.S. Geological Survey Miscellaneous Field Studies Map MF-420, 1 sheet, scale 1:250,000.

Cobb, E.H., 1972, Metallic Mineral Resources Map of the Livengood Quadrangle, Alaska; U.S. Geological Survey Miscellaneous Field Studies Map MF-413, 1 sheet, scale 1:250,000.

Cobb, E.H., 1972, Metallic Mineral Resources Map of the Mount Hayes Quadrangle, Alaska; U.S. Geological Survey Miscellaneous Field Studies Map MF-414, 1 sheet, scale 1:250,000. 
Degenhart, C.E., Griffis, R.J., McOuat, J.F., and Bigelow, C.G., 1978, Mineral Studies of the Western Brooks Range Performed Under Contract to the U.S. Bureau of Mines, Contract \#J0155089, Vol. 1; Bureau of Mines Open-File Report 103-78, 544 p., 11 sheets, scale 1:63,360.

Dover, J.H., 1997, Alaska Resource Date File-Misheguk Mountain Quadrangle; U.S. Geological Survey Open-File Report 97-297, 18 p.

Elliott, R.L., Berg, H.C., and Karl, S.M., 1978, Map and Table Describing Metalliferous and Selected Nonmetalliferous Mineral Deposits, Ketchikan and Prince Rupert Quadrangles; U.S. Geological Survey Open-File Report 78-73-B, 17 p., 1 sheet, scale 1:250,000.

Fernald, A.T., 1964, Surficial Geology of the Central Kobuk River Valley, Northwestern Alaska; U.S. Geological Survey Bulletin 1181-K, 31 p., 1 sheet, scale 1:250,000.

Fisher, R.B., Thorne, R.L., and VanCott, C., 1945, Paligorskite: A Possible Asbestos Substitute; Bureau of Mines Information Circular 7313, 5 p.

Foster, H.L., 1969, Asbestos Occurrence in the Eagle C-4 Quadrangle, Alaska; U.S. Geological Survey Circular 611, 7 p.

Foster, R.L., and Chapman, R.M., 1967, Locations and Descriptions of Lode Prospects in the Livengood Area, East-Central Alaska; U.S. Geological Survey Open-File Report 67-91, 6 p.

Fritts, C.E., 1970, Geology and Geochemistry of the Cosmos Hills, Ambler River and Shungnak Quadrangles, Alaska; Alaska Division of Mines and Geology Report 39, 69 p.

Grybeck, D.J., 1977, Map Showing Known Mineral Deposits of the Brooks Range, Alaska; U.S. Geological Survey Open-File Report 77-166-C, 45 p., 1 sheet, scale 1:1,000,000.

Heide, H.E., Wright, W.S., and Rutledge, F.A., 1944, Dahl Creek Asbestos Deposits, Kobuk River Region, Alaska; Bureau of Mines War Minerals Report 229, 6 p.

Heide, H.E., Wright, W.S., and Rutledge, F.A., 1949, Investigation of the Kobuk River Asbestos Deposits, Kobuk District, Northwestern Alaska; Bureau of Mines Report of Investigations 4414, 25 p.

Lathram, E.H., Loney, R.A., Berg, H.C., and Pomeroy, J.S., 1960, Progress Map of the Geology of Admiralty Island Alaska; U.S. Geological Survey Miscellaneous Geologic Investigations Series Map I-323, 1 sheet, scale 1:250,000.

Mayfield, C.F., and Grybeck, D., 1978, Mineral Occurrences and Resources Map of the Ambler River Quadrangle, Alaska; U.S. Geological Survey Open-File Map 78-120 I, 1 sheet, scale 1:250,000.

Mullins, W.J, McOuat, J.F., and Rogers, R.K., 1984, The Alaska Asbestos Project - Project Review; Proceedings of the Industrial Minerals International Congress 6, p. WJM1-20.

Nelson, S., 1997, Alaska Resource Data File-Ambler River Quadrangle; U.S. Geological Survey Open-File Report 97-856, $98 \mathrm{p}$.

Reed, I., 1931, Report on the Placer Deposits of the Upper Kobuk Goldfields; Alaska Territorial Department of Mines Unpublished Report, 33 p.

Richter, D.H., 1997, Alaska Resource Data File-Nabesna Quadrangle; U.S. Geological Survey Open-File Report 97-749, 93 p.

Saunders, R.H., 1957, Salt Creek Asbestos Deposit; Alaska Territorial Department of Mines Miscellaneous Report MR-48-5, 4 p. 
Smith, P.S, and Mertie, J.B., Jr., 1930, Geology and Mineral Resources of Northwestern Alaska; U.S. Geological Survey Bulletin 815, 315 p.

Smith, P.S., 1913, The Noatak-Kobuk Region, Alaska; U.S. Geological Survey Bulletin 536, 157 p.

Smith, P.S., and Eakin, H.M., 1911, The Shungnak Region, Kobuk Valley; U.S. Geological Survey Bulletin 480, 25 p.

U.S. Bureau of Mines, 1985, Unpublished data, 1970-1985.

U.S. Bureau of Mines, 1995, Spatial Data Extracted from the Minerals Availability System/ Mineral Industry Location System (MAS/MILS); U.S. Bureau of Mines Special Publication 12-95, CDROM.

\section{Barite}

Barker, J.C., 1978, Mineral Investigations of Certain Lands in the Eastern Brooks Range, 1978: A Summary Report; Bureau of Mines Open-File Report 63-78, 25 p.

Barker, J.C., 1981, Mineral Investigations in the Porcupine River Drainage, Alaska; U.S. Bureau of Mines Open-File Report 27-81, 189 p.

Barker, J.C., 1981, Mineral Investigations of Certain Lands in the Eastern Brooks Range, 1978; U.S. Bureau of Mines Open-File Report 37-81, 288 p.

Barker, J.C., and Clautice, K.H., 1978, Mineral Reconnaissance of the Porcupine River Region: A Summary Report; U.S. Bureau of Mines Open File Report 87-78, 20 p.

Barnes, D.F., Mayfield, C.F., Morin, R.L., and Brynn, S., 1982, Gravity Measurements Useful in the Preliminary Evaluation of the Nimiuktuk Barite Deposit, Alaska; Economic Geology, v. 77, p. 185-198.

Bates, R.L., 1969, Geology of the Industrial Minerals; Dover, Publications Inc., New York, 459 p.

Berg, H.C., 1972, Geologic Map of Annette Island, Alaska; U.S. Geological Survey Miscellaneous Geologic Investigations Series Map I-684, 1 sheet, scale 1:63,360.

Berg, H.C., 1984, Regional Geologic Summary, Metallogenesis and Mineral Resources of Southeastern Alaska; U.S. Geological Survey Open-File Report 84-572, 298 p.

Berg, H.C., and Cobb, E.H., 1967, Metalliferous Lode Deposits of Alaska; U.S. Geological Survey Bulletin $1246,254 \mathrm{p}$.

Berg, H.C., Decker, J.E., and Abramson, B.S., 1981, Metallic Mineral Deposits of Southeastern Alaska; U.S. Geological Survey Open-File Report 81-122, 145 p., 1 sheet, scale 1:1,000,000.

Brosge', W.P., and Reiser, H.N., 1977, Lead-Zinc Mineralization at Bear Mountain, Southeastern Brooks Range, in Blean, K.M., ed., The United States Geological Survey in Alaska: Accomplishments During 1976; U.S. Geological Survey Circular 751-B, p. B8-B10.

Brosge, W.P., Reiser, H.N., Dutro, J.T., Jr., and Detterman, R.L., 1979, Generalized Geologic Map of Philip Smith Mountains Quadrangle, Alaska; U.S. Geological Survey Miscellaneous Field Studies Map MF-879-B, 1 sheet, scale 1:250,000. 
Brosge', W.R., and Reiser, H.N., 1968, Geochemical Maps of Granitic Rocks, Coleen and Table Mountain Quadrangles, Alaska; U.S. Geological Survey Open-File Report 323, scale 1:250,000.

Brosge', W.R., and Reiser, H.N., 1969, Preliminary Geologic Map of the Coleen Quadrangle, Alaska; U.S. Geological Survey Open-File Report 69-25, 1 sheet, scale 1:250,000.

Brosge', W.R., and Reiser, H.N., 1976, Preliminary Geologic and Mineral Resource Maps (excluding petroleum), Arctic National Wildlife Range, Alaska; U.S. Geological Survey Open-File Report 76-539, 4 p., scale 1:500,000.

Bundtzen, T.K., and Gilbert, W.G., 1991, Geology and Geochemistry of the Gargaryah Barite Deposit, Western Alaska Range, Alaska; Alaska Division of Geological \& Geophysical Surveys Professional Report 111, p. 9-20.

Bundtzen, T.K., and Henning, M.W., 1978, Barite in Alaska; Mines and Geology Bulletin, Alaska Division of Geological and Geophysical Surveys, v. 27, p. 1-4.

Bundtzen, T.K., and Smith, T.E., 1982, Alaska's Industrial Minerals; Alaska Geographic 9, p. 64-73.

Bundtzen, T.K., Eakins, G.R., and Conwell, C.N., 1982, Review of Alaska's Mineral Resources; Alaska Division of Geological \& Geophysical Surveys and Alaska Department of Commerce and Economic Development, AMR 81-82.

Bundtzen, T.K., Laird, G.M., Blodgett, R.B., Clautice, K.H., and Harris, E.E., 1994, Geology of the Gargaryah River Area, Lime Hills C-5 and C-6 Quadrangles, Southwest Alaska; Alaska Division of Geological and Geophysical Surveys Public-Data File 94-40, 17 p., scale 1:63,360.

Bundtzen, T.K., Swainbank, R.C., Clough, A.H., Henning, M.W., and Charlie, K.M., 1996, Alaska's Mineral Industry 1995; Alaska Division of Geological and Geophysical Surveys, Special Report 50, p. 62 .

Campbell, L.J., 1995, Alaska's Mineral Industry Today; Alaska Geographic, v.22, no.3, p. 31-65.

Churkin, M. Jr., Mayfield, C.F., Theobald, P.K., Barton, H., Nokleberg, W.J., Windler, G.R., and Huie, C., 1978, Geological and Geochemical Appraisal of Metallic Mineral Resources, Southern National Petroleum Reserve in Alaska; U.S. Geological Survey Open-File Report 78-70A, 82 p.

Cobb, E.H., 1972, Metallic Mineral Resources Map of the Big Delta Quadrangle, Alaska; U.S. Geological Survey Miscellaneous Field Studies Map MF-388, 1 sheet, scale 1:250,000.

Cobb, E.H., 1972, Metallic Mineral Resources Map of the Mount Fairweather Quadrangle, Alaska; U.S. Geological Survey Miscellaneous Field Studies Map MF-436, 1 sheet, scale 1:250,000.

Cobb, E.H., 1972, Metallic Mineral Resources Map of the Port Alexander Quadrangle, Alaska; U.S. Geological Survey Miscellaneous Field Studies Map MF-464, 1 sheet, scale 1:250,000.

Cobb, E.H., 1972, Metallic Mineral Resources Map of the Skagway Quadrangle, Alaska; U.S. Geological Survey Miscellaneous Field Studies Map MF-424, 1 sheet, scale 1:250,000.

Cobb, E.H., Mayfield, C.F., Brosge, W.P., 1981, Summaries of Data on and Lists of References to Metallic and Selected Non-Metallic Mineral Occurrences in Eleven Quadrangles in Northern Alaska-Summaries of Data to January 1, 1981; U.S. Geological Survey Open-File Report 81-767, 40 p.

Conwell, C.E., 1970, Palmer Barite Deposit; Alaska Division of Geological \& Geophysical Surveys Prospect Evaluation PE-109-6. 
Degenhart, C.E., Griffis, R.J., McOuat, J.F., and Bigelow, C.G., 1978, Mineral Studies of the Western Brooks Range Performed Under Contract to the U.S. Bureau of Mines, Contract \#J0155089, Vol. 1; Bureau of Mines Open-File Report 103-78, 544 p., 11 sheets, scale 1:63,360.

Dover, J., 1997, Alaska Resource Data File-Colleen Quadrangle; U.S. Geological Survey Open-File Report 97-295, $39 \mathrm{p}$.

Dover, J.H., 1997, Alaska Resource Data File-Table Mountain Quadrangle; U.S. Geological Survey OpenFile Report 97-293, 14 p.

Dover, J.H., 1997, Alaska Resource Date File-Howard Pass Quadrangle; U.S. Geological Survey Open-File Report 97-296, 47 p.

Dover, J.H., 1997, Alaska Resource Date File-Misheguk Mountain Quadrangle; U.S. Geological Survey Open-File Report 97-297, 18 p.

Duttweiler, K.A., 1986, Sulfide Occurrences in the Itkillik River Region, Southeast Chandler Lake Quadrangle, Brooks Range; U.S. Geological Survey Circular 978, p. 10-13.

Edgerton, D., 1997, Reconstruction of the Red Dog Zn-Pb-Ba Orebody, Alaska: Implications for the Vent Environment During the Mineralizing Event; Canadian Journal of Earth Sciences Vol. 34, Number $12,22 \mathrm{p}$.

Elmendorf, W.J., 1920, Lime Point Barite Deposit (Prince of Wales Island); Alaska Territorial Department of Mines Miscellaneous Report MR-119-1, 9 p.

Forrest, K., Rye, R.O., and Sawkins, F.J., 1983, Sulfur and Oxygen Isotope Systematics of Sedimentary Exhalative Zn-Pb-Ag Deposition in a Fault-Bounded Basin, Lik Deposit, Western Brooks Range, Alaska [abs.]; Geological Association of Canada Program with Abstracts,v. 8, p. A23.

Fowler, H.M., 1948, Lime Point Barite Occurrence (Prince of Wales Island); Alaska Territorial Department of Mines Prospect Evaluation PE-119-21, 4 p.

Gaccetta, J.D., and Church, S.E., 1989, Lead Isotope Data Base for Sulfide Occurrences from Alaska, December, 1989; U.S. Geological Survey Open-File Report 89-688, 60 p.

Grybeck, D.J., 1977, Map Showing Known Mineral Deposits of the Brooks Range, Alaska; U.S. Geological Survey Open-File Report 77-166-C, 45 p., 1 sheet, scale 1:1,000,000.

Herreid, G., Bundtzen, T.K., and Turner, K.L., 1978, Geology and Geochemistry of the Craig A-2 Quadrangle and Vicinity, Prince of Wales Island, Southeastern Alaska; Alaska Division of Geological and Geophysical Surveys Geologic Report 48, 49 p.

Jansons, U., 1982, Zinc-lead Occurrences in and Near the National Petroleum Reserve in Alaska; U.S. Bureau of Mines Open-File Report MLA 121-82, 55 p.

Jansons, U., and Baggs, D.W., 1980, Mineral Investigations of the Misheguk Mountains and Howard Pass Quadrangles, National Petroleum Reserve-Alaska; U.S. Bureau of Mines Open-File Report 38-80, $76 \mathrm{p}$.

Jansons, U., and Parke, M.A., 1981, 1978 Mineral Investigations of Misheguk Mountain and Howard Pass Quadrangles, Alaska; Bureau of Mines Open-File Report 26-81, 193 p.

Jewell, P.W., 2000, Bedded Barite in the Geologic Record; SEPM Special Publication No. 66, 15 p. 
Kelley, J.S., Tailleur, I.L., Morin, R.L., Reed, K.M., Harris, A.G., Schmidt, J.M., Brown, F.M., and Kurtak, J.M., 1993, Barite Deposits in the Howard Pass Quadrangle and Possible Relations to Barite Elsewhere in the Northwestern Brooks Range, Alaska; U.S. Geological Survey Open-File Report 93-215, 13 p., 9 sheets, scale 1:63,360.

Kelley, K.D., 1997, Alaska Resource Data File-Chandler Lake Quadrangle; U.S. Geological Survey OpenFile Report 97-265, 24 p.

Kelley, K.D., Leach, D.L., and Johnson, C.A., 1998, Sulfur-, Oxygen-, and Carbon-Isotype Studies of Ag$\mathrm{Pb}-\mathrm{Zn}$ Vein-Breccia Occurrences, Sulfide-Bearing Concretions, and Barite Deposits in the NorthCentral Brooks Range, with Comparisons to Shale-Hosted Stratiform Massive Sulfide Deposits; U.S. Geological Survey Professional Paper 1615, 12 p.

Kurtak, J.M., Hicks, R.W., Werdon, M.B., Meyer, M.P., and Mull, C.G., 1995, Mineral Investigations in the Colville Mining District and Southern National Petroleum Reserve in Alaska; Bureau of Mines Open-File Report, 217 p., 1 sheet, scale 1:250,000.

MacKevett, E.M., Jr., 1971, Analyses of Samples and Preliminary Geologic Summary of Barite-SilverBase Metal Deposits Near Glacier Creek, Skagway B-4 Quadrangle, Southeastern; U.S. Geological Survey Open-File Report 71-195, 8 p.

MacKevett, E.M., Jr., Brew, D.A., Hawley, C.C., Huff, L.C., and Smith, J.G., 1967, Mineral Resources of Glacier Bay National Monument, Alaska; U.S. Geological Survey Open-File Report 67-151, 176 p., 10 sheets, scale 1:125,000.

MacKevett, E.M., Jr., Robertson, E.C., and Winkler, G.R., 1974, Geology of the Skagway B-3 and B-4 Quadrangles, Southeastern Alaska; U.S. Geological Survey Professional Paper 832, 33 p., 1 sheet, scale 1:63,360.

Matson, N.A., and Richter, D.H., 1971, Geochemical Data from the Nabesna A-1 Quadrangle, Alaska; U.S. Geological Survey Open-File Report 71-0202, 10 p.

Mayfield, C.F., and Grybeck, D., 1978, Mineral Occurrences and Resources Map of the Ambler River Quadrangle, Alaska; U.S. Geological Survey Open-File Map 78-120 I, 1 sheet, scale 1:250,000.

Mayfield, C.F., Curtis, S.M., Ellersieck, I.F., and Tailleur, I.L., 1979, The Ginny Creek Zinc-Lead-Silver and Nimiuktuk Barite Deposits, Northwestern Brooks Range, Alaska, in Johnson, K.M., and Williams, J.R., The United States Geological Survey in Alaska: Accomplishments During 1978; U.S. Geological Survey Circular 804-B, p. B14-B16.

Mayfield, C.F., Curtis, S.M., Ellersieck, I.F., and Tailleur, I.L., 1979, Reconnaissance Geology of the Ginny Creek Zinc-Lead-Silver and Nimiuktuk Barite Deposits, Northwestern Brooks Range, Alaska; U.S. Geological Survey Open-File Report 79-1092, 21 p., 2 sheets, scale 1:63,360.

Mayfield, C.G., Tailleur, I.L., Mull, C.G., and Sable, E.G., 1978, Bedrock Geologic Map of the South Half of the National Petroleum Reserve in Alaska; U.S. Geological Survey Open-File Report 78-70-B.

Meyer, M.P., 1994, Analytical Results from U.S. Bureau of Mines Investigations in the Colville Mining District, Alaska; U.S. Bureau of Mines Open-File Report 34-94, 137 p.

Meyer, M.P., and Kurtak, J.M., 1992, Results of the 1991 U.S. Bureau of Mines Colville Mining District Study; U.S. Bureau of Mines Open-File Report 75-92, 101 p.

Moore, D.W., Young, L.E., Modene, J.S., and Plahuta, J.T., 1986, Geologic Setting and Genesis of the Red Dog Zinc-Lead-Silver Deposit, Western Brooks Range, Alaska; Economic Geology, v. 81, p. 1696-1727. 
Morin, R.L., 1997, Gravity Models of Abby Creek and Bion Barite Deposits, Howard Pass Quadrangle, Northwestern Brooks Range, Alaska; U.S. Geological Survey Open-File Report 97-704, 15 p.

Nelson, S., 1997, Alaska Resource Data File-Ambler River Quadrangle; U.S. Geological Survey Open-File Report 97-856, 98 p.

Nelson, S.W., Nokleberg, W.J., Miller-Hoare, M., and Mullen, M.W., 1979, Siniktanneyak Mountain Ophiolite, in Johnston, K.M., and Williams, J.R., The United States Geological Survey in Alaska: Accomplishments During 1978; U.S. Geological Survey Circular 804-B, p. B14-B16.

Nokleberg, W.J., and Winkler, G.R., 1978, Geologic Setting of the Lead and Zinc Deposits, Drenchwater Creek Area, Howard Pass Quadrangle, Alaska; U.S. Geological Survey Open-File Report 78-70C, 16 p., 1 sheet, scale 1:19,800.

Nokleberg, W.J., and Winkler, G.R., 1978, Stratiform Zinc-Lead Mineralization, Drenchwater Creek Area, Howard Pass Quadrangle, Western Brooks Range, Alaska; U.S. Geological Survey Circular 772B, p. B15-B17.

Nokleberg, W.J., Plafker, G., and Wilson, F.H., 1994, Geology of Southcentral Alaska; Boulder, Colorado, Geological Society of America, Geology of North America, v. G1, p. 311-366.

Oyler, H., 1993, Baroid Corp. Houston, Texas; Personal Communication, December 1993.

Paris, C., 1977, Models of Barite Deposition with Reference to the Barite Occurrence of Atigun Canyon, Central Brooks Range, Alaska; Fairbanks, Alaska, University of Alaska, Unpublished Report, 45 p.

Plahuta, J.T., 1978 Geologic Map and Cross Sections of the Red Dog Prospect, DeLong Mountains, Northwestern Alaska; Bureau of Mines Open-File Report 65-78.

Richter, D.H., 1971, Reconnaissance Geologic Map, and Section of the Nabesna A-3 Quadrangle, Alaska; U.S. Geological Survey Miscellaneous Investigations Series Map I-655, 1 sheet, scale 1:63,360.

Richter, D.H., 1997, Alaska Resource Data File-Nabesna Quadrangle; U.S. Geological Survey Open-File Report 97-749, 93 p.

Richter, D.H., and Matson, N.A., 1969, Geochemical Data from the Nabesna A-3 Quadrangle, Alaska; U.S. Geological Survey Open-File Report 69-223, 5 p., 1 sheet, scale 1:63,360.

Richter, D.H., and Matson, N.A., Jr., 1972, Metallic Mineral Resources Map of the Gulkana Quadrangle, Alaska; U.S. Geological Survey Miscellaneous Field Studies Map MF-419, 1 sheet, scale $1: 250,000$.

Richter, D.H., and Others, 1973, Reconnaissance Geologic Map of the Nabesna A-1 Quadrangle, Alaska; U.S. Geological Survey Miscellaneous Investigations Series Map I-807, 1 sheet, scale 1:63,360.

Richter, D.H., Singer, D.A., and Cox, D.P., 1975, Mineral Resources Map of the Nabesna Quadrangle, Alaska; U.S. Geological Survey Miscellaneous Field Studies Map MF-655-K, 1 sheet, scale $1: 250,000$.

Schmidt, J.M., and Werdon, M.B., 1993, Clastic-hosted Stratiform, Vein/ Breccia and Disseminated Zn-PbAg Deposits of the Northwestern Brooks Range, Alaska: Are They Different Expressions of Dewatering of the Same Source Basin? [abs.]; Geological Society of America, Abstracts with Programs, v. 24, p. 143. 
Schmidt, Jeanine M., 1997, Shale-Hosted Zn-Pb-Ag and Barite Deposits of Alaska; Economic Geology Monograph 9, 31 p.

Still, J.C., 1984, Stratiform Massive Sulfide Deposits of the Mt. Henry Clay Area, Southeast Alaska; Bureau of Mines Open-File Report 118-84, 62 p.

Tailleur, I.L., Eberlein, G.D., and Wehr, R., 1970, Lead-Zinc and Barite-Bearing Samples From the Western Brooks Range, Alaska. With a Section on Petrography and Mineralogy; U.S. Geological Survey Open-File Report 70-319, 16 p.

Tailleur, I.L., Kent, B.H., and Reiser, H.N., 1966, Outcrop/ Geologic Maps of the Nuka-Etivluk Region, Northern Alaska; U.S. Geological Survey Open-File Report 66-128 (226).

Twenhofel, W.S., Reed, J.C., and Gates, G.O., 1949, Some Mineral Investigations in Southeastern Alaska; U.S. Geological Survey Bulletin 963-A, 44 p.

U.S. Bureau of Mines, 1973, Alaska 1:250,000 Scale Quadrangle Map Overlays Showing Mineral Deposit Locations, Principal Minerals, and Number and Type of Claims; Bureau of Mines Open-File Report 20-73, 41 p.

U.S. Bureau of Mines, 1995, Spatial Data Extracted from the Minerals Availability System/ Mineral Industry Location System (MAS/MILS); U.S. Bureau of Mines Special Publication 12-95, CDROM.

U.S. Department of Labor, Mine Safety and Health Administration, 1985, Mine Safety and Health Examinations, 1975-1985.

U.S. Geological Survey, 1977, Geological Survey Research, 1977; U.S. Geological Survey Professional Paper 1050, $411 \mathrm{p}$.

U.S. Geological Survey, 1988, Geology and Exploration of the National Petroleum Reserve in Alaska, 1974 to 1982; U.S. Geological Survey Professional Paper 1399, 940 p.

U.S. Geological Survey, 1990, Generalized Geologic Map of the Chandler Lake Quadrangle, North-Central Alaska; U.S. Geological Survey Miscellaneous Field Studies Map MF-2144-A.

U.S. Geological Survey, 1992, U.S. Geological Survey Emeritus; Written Communication, October 1992.

Williams, J.A., 1951, Juneau, Sitka, and Petersburg Precincts; Alaska Territorial Department of Mines Itinerary Report IR-191-1, 5 p.

Young, L.E., 1989, Geology and genesis of the Red Dog deposit, western Brooks Range, Alaska; CIM Bulletin Vol. 82, No. 929, 11 p.

\section{Calcium}

Barker, J.C., Still, J.C., Mowatt, T.C., and Mulligan, J.J., 1981, Critical and Strategic Minerals in Alaska: Cobalt, the Platinum-Group Metals, and Chromite; Bureau of Mines Information Circular 8869, 8 p., 1 sheet, scale 1:250,000.

Bittenbender, P.E., Still, J.C., Maas, K.M., and McDonald, M.E., Jr., 1999, Mineral Resources of the Chichagof and Baranof Islands Area, Southeast Alaska; U.S. Bureau of Land Management Technical Rep. 19, 222 p., 3 sheets, scales 1:63,360 and 1:12,000. 
Bundtzen, T.K., Laird, G.M., and Gilbert, W.G., 1989, Material Studies Along Kuskokwim River, McGrath to Kalskag, Southwest Alaska; Alaska Division of Geological \& Geophysical Surveys Public Data File PDF 89-16, 84 p.

Cobb, E.H., 1972, Metallic Mineral Resources Map of the Sumdum Quadrangle, Alaska; U.S. Geological Survey Miscellaneous Field Studies Map MF-425, 1 sheet, scale 1:250,000.

Herreid, G.H., 1961, Morey-Quinlan-Tengs Limestone Property (Mile 39, Haines Highway, Klukwan); Alaska Territorial Department of Mines Prospect Evaluation PE-109-4, 6 p., 1 map.

Jasper, M.W., and Mihelich, M., 1961, Permanente Cement Limestone (East Fork Kings River); Alaska Territorial Department of Mines Prospect Evaluation PE-85-22, 17 p., 2 sheets, scale 1:63,360.

Kaufman, A., 1958, Southeastern Alaska's Mineral Industry; Bureau of Mines Information Circular 7844, $37 \mathrm{p}$.

MacKevett, E.M., Jr., Robertson, E.C., and Winkler, G.R., 1974, Geology of the Skagway B-3 and B-4 Quadrangles, Southeastern Alaska; U.S. Geological Survey Professional Paper 832, 33 p., 1 sheet, scale $1: 63,360$.

Roehm, J.C., 1946, Some High Calcium Limestone Deposits in Southeastern Alaska; Alaska Territorial Department of Mines Pamphlet 6, 20 p.

Thorne, R.L., and Wells, R.R., 1956, Studies of the Snettisham Magnetite Deposit, Southeastern Alaska; Bureau of Mines Report of Investigations 5195, 41 p.

Twenhofel, W.S., Reed, J.C., and Gates, G.O., 1949, Some Mineral Investigations in Southeastern Alaska; U.S. Geological Survey Bulletin 963-A, 44 p.

U.S. Department of Labor, Mine Safety and Health Administration, 1985, Mine Safety and Health Examinations, 1975-1985.

Williams, J.A., 1951, Juneau, Sitka, and Petersburg Precincts; Alaska Territorial Department of Mines Itinerary Report IR-191-1, 5 p.

\section{Clay}

Bundtzen, T.K., and Smith, T.E., 1982, Alaska's Industrial Minerals, Alaska Geographic 9, p. 64-73.

Detterman, R.L., Plafker, G., Tysdal, R.G., and Hudson, T.,1976, Geology and Surface Features Along Part of the Talkeetna Segment of the Castle Mountain-Caribou Fault System, Alaska; U. S. Geological Survey Miscellaneous Field Studies Map MF-738, 1 sheet, scale 1:63,360.

Jasper, M.W., 1953, J. Fabian and D. Moore Clay Deposit (Little Susitna River); Alaska Territorial Department of Mines Prospect Evaluation PE-85-18, 1 p.

Tysdal, R.G., 1979, Mines, Prospects, and Occurrences Map of the Seward and Blying Sound Quadrangles, Alaska; U.S. Geological Survey Miscellaneous Field Studies Map MF-880-A, 2 sheets, scale $1: 250,000$. 


\section{Diatomite}

Cobb, E.H., 1975, Summary of References to Mineral Occurrences (Other Than Mineral Fuels and Construction Materials) in the Bendeleben Quadrangle, Alaska; U.S. Geological Survey Open-File Report 75-429, 123 p.

Plafker, G., and MacKevett, E.M., Jr, 1956, Occurrence of Diatomaceous Earth Near Kenai, Alaska; U.S. Geological Survey Bulletin 1039-B, 6 p.

\section{Flourine}

Barker, J.C., 1978, Mineral Investigations of Certain Lands in the Eastern Brooks Range, 1978: A Summary Report; Bureau of Mines Open-File Report 63-78, 25 p.

Bates, R.L., 1969, Geology of the Industrial Minerals; Dover, Publications Inc., New York, 459 p.

Berg, H.C., and Cobb, E.H., 1967, Metalliferous Lode Deposits of Alaska; U.S. Geological Survey Bulletin $1246,254 \mathrm{p}$.

Brosge', W.R., and Reiser, H.N., 1976, Preliminary Geologic and Mineral Resource Maps (excluding petroleum), Arctic National Wildlife Range, Alaska; U.S. Geological Survey Open-File Report 76-539, 4 p., scale 1:500,000.

Bundtzen, T.K., Eakins, G.R., and Conwell, C.N., 1982, Review of Alaska's Mineral Resources; Alaska Division of Geological \& Geophysical Surveys and Alaska Department of Commerce and Economic Development, AMR 81-82.

Cobb, E.H., 1972, Metallic Mineral Resource Map of the Fairbanks Quadrangle, Alaska; U.S. Geological Survey Miscellaneous Field Studies Map MF-410, 1 sheet, scale 1:250,000.

Cobb, E.H., 1972, Metallic Mineral Resources Map of the Circle Quadrangle, Alaska; U.S. Geological Survey Miscellaneous Field Studies Map MF-391, 1 sheet, scale 1:250,000.

Cobb, E.H., 1972, Metallic Mineral Resources Map of the Petersburg Quadrangle, Alaska; U.S. Geological Survey Miscellaneous Field Studies Map MF-415, 1 sheet, scale 1:250,000.

Cobb, E.H., 1975, Summary of References to Mineral Occurrences (Other Than Mineral Fuels and Construction Materials) in the Bendeleben Quadrangle, Alaska; U.S. Geological Survey Open-File Report 75-429, 123 p.

Cobb, E.H., Mayfield, C.F., Brosge, W.P., 1981, Summaries of Data on and Lists of References to Metallic and Selected Non-Metallic Mineral Occurrences in Eleven Quadrangles in Northern Alaska-Summaries of Data to January 1, 1981; U.S. Geological Survey Open-File Report 81-767, 40 p.

Degenhart, C.E., Griffis, R.J., McOuat, J.F., and Bigelow, C.G., 1978, Mineral Studies of the Western Brooks Range Performed Under Contract to the U.S. Bureau of Mines, Contract \#J0155089, Vol. 1; Bureau of Mines Open-File Report 103-78, 544 p., 11 sheets, scale 1:63,360.

Dover, J.H., 1997, Alaska Resource Data File-Arctic Quadrangle; U.S. Geological Survey Open-File Report 97-292, 19 p.

Grybeck, D.J., 1977, Map Showing Known Mineral Deposits of the Brooks Range, Alaska; U.S. Geological Survey Open-File Report 77-166-C, 45 p., 1 sheet, scale 1:1,000,000. 
Heide, H.E., 1943, Lost River Mines, Seward Peninsula, Alaska-Tin; Bureau of Mines War Minerals Report 45, 9 p.

Hudson, T.L., Miller, M.L., and Peckthorn, W.J., 1977, Map Showing Metalliferous and Selected Nonmetalliferous Mineral Deposits, Seward Peninsula, Alaska; U.S. Geological Survey Open-File Report 77-796-B, 46 p., 1 sheet, scale 1:1,000,000.

Jansons, U., and Baggs, D.W., 1980, Mineral Investigations of the Misheguk Mountains and Howard Pass Quadrangles, National Petroleum Reserve-Alaska; U.S. Bureau of Mines Open-File Report 38-80, $76 \mathrm{p}$.

Jansons, U., and Parke, M.A., 1981, 1978 Mineral Investigations of Misheguk Mountain and Howard Pass Quadrangles, Alaska; Bureau of Mines Open-File Report 26-81, 193 p.

Kelley, J.S., 1996, Alaska Resource Data File-Demarcation Point Quadrangle; U.S. Geological Survey Open-File Report 96-678, 14 p.

Kelley, K.D., 1997, Alaska Resource Data File-Chandler Lake Quadrangle; U.S. Geological Survey OpenFile Report 97-265, 24 p.

Kurtak, J.M., Hicks, R.W., Werdon, M.B., Meyer, M.P., and Mull, C.G., 1995, Mineral Investigations in the Colville Mining District and Southern National Petroleum Reserve in Alaska; Bureau of Mines Open-File Report 8-95, 217 p., 1 sheet, scale 1:250,000.

Lorain, S.H., Wells, R.R., Mihelich, M., Mulligan, J.J., Thorne, R.L., and Herdlick, J.A., 1958, Lode-Tin Mining at Lost River, Seward Peninsula, Alaska; Bureau of Mines Information Circular 7871, $76 \mathrm{p}$.

Lost River Mining Corp., Ltd. (Toronto), 1972, Annual Report, 1972; Lost River Mining Corporation Ltd, $15 \mathrm{p}$.

Mayfield, C.F., and Grybeck, D., 1978, Mineral Occurrences and Resources Map of the Ambler River Quadrangle, Alaska; U.S. Geological Survey Open-File Map 78-120 I, 1 sheet, scale 1:250,000.

Nelson, S., 1997, Alaska Resource Data File-Ambler River Quadrangle; U.S. Geological Survey Open-File Report 97-856, 98 p.

U.S. Bureau of Mines, 1985, Unpublished data, 1970-1985.

Williams, J.A., and Saunders, R.H., 1953, Lost River Geophysical Work--Tin Deposit; Alaska Territorial Department of Mines Prospect Evaluation PE-43-2, 21 p.

Williams, J.A., and Saunders, R.H., 1954, Magnetic Exploration of Cape Mountain Placer-Tin Deposits; Alaska Territorial Department of Mines Prospect Evaluation PE-43-3, 15 p., 6 maps, scale $1: 2,400$.

\section{Gemstone}

Anderson, E., 1945, Asbestos and Jade Occurrences in the Kobuk River Region, Alaska; Alaska Territorial Department of Miners Pamphlet 3-R, 48 p.

Anderson, E., 1947, Mineral Occurrences Other Than Gold Deposits in Northwest Alaska; Alaska Territorial Department of Mines Pamphlet 5-R, 48 p. 
Bain, H.F., 1946, Alaska's Minerals as a Basis for Industry; Bureau of Mines Information Circular 7379, $89 \mathrm{p}$.

Berg, H.C., 1999, Alaska Resource Data File-Prince Rupert Quadrangle; U.S. Geological Survey Open-File Report 99-306, 16 p.

Berg, H.C., Elliott, R.L., and Koch, R.D., 1988, Geologic Map of the Ketchikan and Prince Rupert Quadrangles, Southeastern Alaska; U.S. Geological Survey Miscellaneous Investigations Series Map I-1807, 1 sheet, scale 1:250,000.

Bundtzen, T.K., Eakins, G.R., and Conwell, C.N., 1982, Review of Alaska's Mineral Resources; Alaska Division of Geological \& Geophysical Surveys and Alaska Department of Commerce and Economic Development, AMR 81-82.

Cobb, E.H, 1972, Metallic Mineral Resources Map of the Ambler River Quadrangle, Alaska; U.S. Geological Survey Miscellaneous Field Studies Map MF-454, 1 sheet, scale 1:250,000.

Cobb, E.H., 1972, Metallic Mineral Resources Map of the Hagemeister Island Quadrangle, Alaska; U.S. Geological Survey Miscellaneous Field Studies Map MF-362, 1 sheet, scale 1:250,000.

Cobb, E.H., 1972, Metallic Mineral Resources Map of the Shungnak Quadrangle, Alaska; U.S. Geological Survey Miscellaneous Field Studies Map MF-448, 1 sheet, scale 1:250,000.

Cobb, E.H., 1973, Metallic Mineral Resources Map of the Craig Quadrangle, Alaska; U.S. Geological Survey Miscellaneous Field Studies Map MF-433, 1 sheet, scale 1:250,000.

Elliott, R.L., Berg, H.C., and Karl, S.M., 1978, Map and Table Describing Metalliferous and Selected Nonmetalliferous Mineral Deposits, Ketchikan and Prince Rupert Quadrangles, Alaska; U.S. Geological Survey Open-File Report 78-73-B, 17 p., 1 sheet, scale 1:250,000.

Fechner, S.A., 1988, Bureau of Mines Mineral Investigation of the Goodnews Bay Mining District, Alaska; Bureau of Mines Open-File Report 1-88, 230 p.

Fernald, A.T., 1964, Surficial Geology of the Central Kobuk River Valley, Northwestern Alaska; U.S. Geological Survey Bulletin 1181-K, 31 p., 1 sheet, scale 1:250,000.

Forbes, R.B., Kline, J.T., and Clough, A.H., 1987, A Preliminary Evaluation of Alluvial Diamond Discoveries in Placer Gravels of Crooked Creek, Circle District, Alaska; Alaska Division of Geological \& Geophysical Surveys Report of Investigations RI-87-1, 26 p.

Fritts, C.E., 1970, Geology and Geochemistry of the Cosmos Hills, Ambler River and Shungnak Quadrangles, Alaska; Alaska Division of Mines and Geology Report 39, 69 p.

Heide, H.E., Wright, W.S., and Rutledge, F.A., 1944, Dahl Creek Asbestos Deposits, Kobuk River Region, Alaska; Bureau of Mines War Minerals Report 229, 6 p.

Heide, H.E., Wright, W.S., and Rutledge, F.A., 1949, Investigation of the Kobuk River Asbestos Deposits, Kobuk District, Northwestern Alaska; Bureau of Mines Report of Investigations 4414, 25 p.

Hoare, J.M., and Coonrad, W.L., 1961, Geologic Map of the Hagemeister Island Quadrangle, Alaska; U.S. Geological Survey Miscellaneous Geologic Investigations Series Map I-321, 1 sheet, scale $1: 250,000$.

Matson, N.A., and Richter, D.H., 1971, Geochemical Data from the Nabesna C-5 Quadrangle, Alaska; U.S. Geological Survey Open-File Report 71-0204, 10 p. 
Mayfield, C.F., and Grybeck, D., 1978, Mineral Occurrences and Resources Map of the Ambler River Quadrangle, Alaska; U.S. Geological Survey Open-File Map 78-120 I, 1 sheet, scale 1:250,000.

Myers, L., and Myers, M., 1999, The Epidote Crystals of Green Monster Mountain; Rock \& Gem, January 1999, p. 64-67.

Nelson, S., 1997, Alaska Resource Data File-Ambler River Quadrangle; U.S. Geological Survey Open-File Report 97-856, 98 p.

Reed, I., 1931, Report on the Placer Deposits of the Upper Kobuk Goldfields; Alaska Territorial Department of Mines Unpublished Report, 33 p.

Richter, D.H., 1967, Geology of the Upper Slana-Mentasta Pass Area, South-Central Alaska; Alaska Division of Geological and Geophysical Surveys Geological Report 30, 27 p., 1 sheet, scale $1: 63,360$.

Richter, D.H., 1970, A Corundum Occurrence in the Eastern Alaska Range, Alaska; U.S. Geological Survey Professional Paper 700-C, p. C98-C102.

Richter, D.H., 1997, Alaska Resource Data File-Nabesna Quadrangle; U.S. Geological Survey Open-File Report 97-749, $93 \mathrm{p}$.

Richter, D.H., and Matson, N.A., Jr., 1972, Metallic Mineral Resources Map of the Nabesna Quadrangle, Alaska; U.S. Geological Survey Miscellaneous Field Studies Map MF-422, 1 sheet, scale $1: 250,000$.

Richter, D.H., and Schmoll, 1973, Geologic Map of the Nabesna C-5 Quadrangle, Alaska; U.S. Geological Survey Geologic Quadrangle Map GQ-1062, 1 sheet, scale 1:63,360.

Richter, D.H., Singer, D.A., and Cox, D.P., 1975, Mineral Resources Map of the Nabesna Quadrangle, Alaska; U.S. Geological Survey Miscellaneous Field Studies Map MF-655-K, 1 sheet, scale $1: 250,000$.

Sainsbury, C.L., 1957, Some Pegmatite Deposits in Southeastern Alaska; U.S. Geological Survey Bulletin 1024-G, p. 141-161.

Smith, P.S., 1913, The Noatak-Kobuk Region, Alaska; U.S. Geological Survey Bulletin 536, 157 p.

Smith, P.S., and Eakin, H.M., 1911, The Shungnak Region, Kobuk Valley; U.S. Geological Survey Bulletin 480, $25 \mathrm{p}$.

Southworth, D.D., and Foley, J.Y., 1986, Lode Platinum-Group Metals Potential of the Goodnews Bay Ultramafic Complex, Alaska; Bureau of Mines Open-File Report 51-86, 82 p., 2 sheets, scale $1: 63,360$.

\section{Graphite}

Cobb, E.H., 1972, Metallic Mineral Resources Map of the Petersburg Quadrangle, Alaska; U.S. Geological Survey Miscellaneous Field Studies Map MF-415, 1 sheet, scale 1:250,000.

Cobb, E.H., 1979, Summary of References to Mineral Occurrences (other than minerals fuels and construction materials) in the Seldovia Quadrangle, Alaska; U.S. Geological Survey Open-File Report 80-87, 47 p. 
Huber, Jeff, 1999, Alaska Resource Data File-Seldovia Quadrangle; U.S. Geological Survey Open-File Report 99-391, $70 \mathrm{p}$.

Hudson, T.L., Miller, M.L., and Peckthorn, W.J., 1977, Map Showing Metalliferous and Selected Nonmetalliferous Mineral Deposits, Seward Peninsula, Alaska; U.S. Geological Survey Open-File Report 77-796-B, 46 p., 1 sheet, scale 1:1,000,000.

Hummel, C.H., 1962, Preliminary Geologic Map of the Nome D-1 Quadrangle, Seward Peninsula, Alaska; U.S. Geological Survey Miscellaneous Field Studies Map MF-248, 1 sheet, scale 1:63,360.

Saunders, R.H., 1958, Coben Graphite Prospect (French Creek); Alaska Territorial Department of Mines Prospect Evaluation PE-59-2, 2 p.

Martin, G.C., 1920, The Alaskan Mining Industry in 1918; U.S. Geological Survey Bulletin 712, p. 11-52.

U.S. Bureau of Mines, 1945, Imuruk Basin, Seward Peninsula, Alaska-Graphite; Bureau of Mines Draft Preliminary War Minerals Report 4501.

\section{Gypsum}

Bittenbender, P.E., Still, J.C., Maas, K.M., and McDonald, M.E., Jr., 1999, Mineral Resources of the Chichagof and Baranof Islands Area, Southeast Alaska; U.S. Bureau of Land Management Technical Report 19, 222 p., 3 sheets, scales 1:63,360 and 1:12,000.

Bundtzen, T.K., and Smith, T.E., 1982, Alaska's Industrial Minerals; Alaska Geographic v. 9, p. 64-73.

Campbell, L.J., 1995, Alaska's Mineral Industry Today; Alaska Geographic, v.22, no.3, p. 31-65.

Churkin, M. Jr., Mayfield, C.F., Theobald, P.K., Barton, H., Nokleberg, W.J., Windler, G.R., and Huie, C., 1978, Geological and Geochemical Appraisal of Metallic Mineral Resources, Southern National Petroleum Reserve in Alaska; U.S. Geological Survey Open-File Report 78-70A, 82 p.

Cobb, E.H., Mayfield, C.F., Brosge, W.P., 1981, Summaries of Data on and Lists of References to Metallic and Selected Non-Metallic Mineral Occurrences in Eleven Quadrangles in Northern Alaska-Summaries of Data to January 1, 1981; U.S. Geological Survey Open-File Report 81-767, 40 p.

Dover, J.H., 1997, Alaska Resource Date File-Misheguk Mountain Quadrangle; U.S. Geological Survey Open-File Report 97-297, 18 p.

Flint, G.M., Jr., and Cobb, E.H., 1953, Gypsum Deposits Near Iyoukeen Cove, Chichagof Island, Southeastern Alaska; U.S. Geological Survey Bulletin 989-B, 10 p., 1 sheet, scale 1:4,800.

Gustafson, F.D., 1946, Camel-Gypsum Group (Iyoukeen Cove); Alaska Territorial Department of Mines Miscellaneous Report MR-114-6, 61 p., 3 maps.

Herreid, G.H., 1962, Camel Gypsum Property (Iyoukeen Cove); Alaska Territorial Department of Mines Prospect Evaluation PE-114-14, 5 p., 1 map.

Jermain, G.D., and Rutledge, F.A., 1952, Diamond Drilling the Gypsum-Camel Prospect, Iyoukeen Cove, Chichagof Island, Southeastern Alaska; Bureau of Mines Report of Investigations 4852, 6 p.

Richter, D.H., 1971, Reconnaissance Geologic Map, and Section of the Nabesna A-3 Quadrangle, Alaska; U.S. Geological Survey Miscellaneous Investigations Series Map I-655, 1 sheet, scale 1:63,360. 
Richter, D.H., 1997, Alaska Resource Data File-Nabesna Quadrangle; U.S. Geological Survey Open-File Report 97-749, 93 p.

Richter, D.H., and Matson, N.A., 1969, Geochemical Data from the Nabesna A-3 Quadrangle, Alaska; U.S. Geological Survey Open-File Report 69-223, 5 p., 1 sheet, scale 1:63,360.

Stewart, B.D., 1931, Mineral Resources of the Chichagof Island; Alaska Territorial Department of Mines Miscellaneous Report MR-114-3, 5 p.

\section{Kyanite Group}

Cobb, E.H., 1972, Metallic Mineral Resources Map of the Bendeleben Quadrangle, Alaska; U.S. Geological Survey Miscellaneous Field Studies Map MF-417, 1 sheet, scale 1:250,000.

\section{Mica}

Anderson, E., 1943, Pargon Mountain Muscovite Prospect (Seward Peninsula); Alaska Territorial Department of Mines Mineral Investigation MI-44-1, 9 p., 2 maps.

Berg, H.C., 1999, Alaska Resource Data File-Prince Rupert Quadrangle; U.S. Geological Survey Open-File Report 99-306, 16 p.

Berg, H.C., Elliott, R.L., and Koch, R.D., 1988, Geologic Map of the Ketchikan and Prince Rupert Quadrangles, Southeastern Alaska; U.S. Geological Survey Miscellaneous Investigations Series Map I-1807, 1 sheet, scale 1:250,000.

Cobb, E.H., 1975, Summary of References to Mineral Occurrences (Other Than Mineral Fuels and Construction Materials) in the Bendeleben Quadrangle, Alaska; U.S. Geological Survey Open-File Report 75-429, 123 p.

Cobb, E.H., and Elliott, R.L., 1980, Summary of Data on and Lists of References to Metallic and Selected Nonmetallic Mineral Deposits in the Ketchikan and Prince Rupert Quadrangles, Alaska; U.S. Geological Survey Open-File Report 80-1053, 156 p.

Elliott, R.L., Berg, H.C., and Karl, S.M., 1978, Map and Table Describing Metalliferous and Selected Nonmetalliferous Mineral Deposits, Ketchikan and Prince Rupert Quadrangles, Alaska; U.S. Geological Survey Open-File Report 78-73-B, 17 p., 1 sheet, scale 1:250,000.

Roehm, J.C, 1945, Preliminary Report of Investigations and Itinerary of J.C. Roehm in the Ketchikan and Hyder Mining Precincts, July 14-August 18, 1945; Alaska Territorial Department of Mines Itinerary Report IR-195-36, 14 p.

Sainsbury, C.L., 1957, Some Pegmatite Deposits in Southeastern Alaska; U.S. Geological Survey Bulletin 1024-G, p. 141-161.

U.S. Bureau of Mines, 1974, Claim Map, Prince Rupert; U.S. Bureau of Mines Map, no. 122, 1 sheet, scale $1: 250,000$.

\section{Perlite}

U.S. Geological Survey, 1963, Contributions to Economic Geology of Alaska; U.S. Geological Survey Bulletin 1155, $93 \mathrm{p}$. 


\section{Phosphate}

Barker, J.C., Still, J.C., Mowatt, T.C., and Mulligan J.J., 1981, Critical and Strategic Minerals in Alaska: Cobalt, the Platinum-Group Metals, and Chromite; Bureau of Mines Information Circular 8869, 8 p., 1 sheet, scale 1:250,000.

Cobb, E.H., 1972, Metallic Mineral Resources Map of the Kenai Quadrangle, Alaska; U.S. Geological Survey Miscelaneous Field Studies Map MF-377, 1 sheet, scale 1:250,000.

Cobb, E.H., 1972, Metallic Mineral Resources Map of the Mt. Michelson Quadrangle, Alaska; U.S. Geological Survey Miscelaneous Field Studies Map MF-462, 1 sheet, scale 1:250,000.

Cobb, E.H., 1972, Metallic Mineral Resources Map of the Sumdum Quadrangle, Alaska; U.S. Geological Survey Miscelaneous Field Studies Map MF-425, 1 sheet, scale 1:250,000.

Cobb, E.H., 1975, Summary of References to Mineral Occurrences (other than mineral fuels and construction materials) in Northern Alaska; U.S. Geological Survey Open-File Report 75-628, 106 p.

Cobb, E.H., Mayfield, C.F., Brosge, W.P., 1981, Summaries of Data on and Lists of References to Metallic and Selected Non-Metallic Mineral Occurrences in Eleven Quadrangles in Northern Alaska-Summaries of Data to January 1, 1981; U.S. Geological Survey Open-File Report 81-767, 40 p.

Detterman, R.L., 1989, Triassic Phosphate Deposits, North-Eastern Alaska, USA; Phosphate Deposits of the World, vol. 2, p. 14-17.

Dover, J.H., 1997, Alaska Resource Date File-Howard Pass Quadrangle; U.S. Geological Survey Open-File Report 97-296, 47 p.

Grantz, A., 1956, Magnetite Deposits at Tuxedni Bay, Alaska; U.S. Geological Survey Bulletin 1024-D, $11 \mathrm{p}$.

Grybeck, D.J., 1977, Map Showing Known Mineral Deposits of the Brooks Range, Alaska; U.S. Geological Survey Open-File Report 77-166-C, 45 p., 1 sheet, scale 1:1,000,000.

Harben, P.W., 1984, Geology of the Nonmetallics; Metal Bulletin Inc., New York, 392 p.

Heiner, L.E., and Wolff, E.N., 1968, Mineral Resources of Northern Alaska, Final Report Submitted to the North Commission; Mineral Industry Research Laboratory, University of Alaska, Report 16, 306 p., 3 sheets, scales 1:1,000,000 and 1:5,000,000.

Jansons, U., and Baggs, D.W., 1980, Mineral Investigations of the Misheguk Mountains and Howard Pass Quadrangles, National Petroleum Reserve-Alaska; U.S. Bureau of Mines Open-File Report 38-80, $76 \mathrm{p}$.

Kaufman, A., 1958, Southeastern Alaska's Mineral Industry; Bureau of Mines Information Circular 7844, $37 \mathrm{p}$.

Kelley, J.S., 1982, Phosphate and Whole Rock Chemical Analyses from Upper Paleozoic and Lower Mexozoic Strata in the Chandler Lake and Killik River Quadrangles, Alaska; U.S. Geological Survey Unpublished Report.

Kelley, K.D., 1997, Alaska Resource Data File-Chandler Lake Quadrangle; U.S. Geological Survey OpenFile Report 97-265, 24 p. 
Kelley, K.D., 1997, Alaska Resource Data File-Killik River Quadrangle; U.S. Geological Survey Open-File Report 97-266, 20 p.

Kurtak, J.M., Hicks, R.W., Werdon, M.B., Meyer, M.P., and Mull, C.G., 1995, Mineral Investigations in the Colville Mining District and Southern National Petroleum Reserve in Alaska; Bureau of Mines Open-File Report 8-95, 217 p., 1 sheet, scale 1:250,000.

LeFond, S.J., ed., 1983, Industrial Minerals and Rocks; Society of Mining Engineers, 2 vol., 1433 p.

Meyer, M.P., 1994, Analytical Results from U.S. Bureau of Mines Investigations in the Colville Mining District, Alaska; U.S. Bureau of Mines Open-File Report 34-94, 137 p.

O'Conner, W.K., 1992, BuMines Research Center, Salt Lake City, Utah; Written Communication, November 1992.

Patton, W.W., Jr., and Matzko, J.J., 1959, Phosphate Deposits in Northern Alaska; U.S. Geological Survey Professional Paper 302-A, 17 p.

Patton, W.W., Jr., and Tailleur, I.L., 1964, Geology of the Upper Killik-Itkillik Region, Alaska; U.S. Geological Survey Professional Paper 303-G, 90 p.

Perkins, W, Jr., 1994, Simplot Co., Afton, Wyoming; Written Communication, April 1994.

Summers, C.A., 1992, Mineralogy of the Ivotuk Hills Phosphate Occurrence, Colville Mining District, Alaska; U.S. Bureau of Mines, Unpublished Report, 6 p.

Tailleur, I.L., Pessel, G.H., Brosge', W.P., and Mayfield, C.F., 1976, Informal Cooperation Between U.S. Geological Survey and State of Alaska, Division of Geological and Geophysical Surveys, in the Brooks Range, in Cobb, E.H., ed., The United States Geological Survey in Alaska: Accomplishments During 1975; U.S. Geological Survey Circular 733, p. 29.

Thorne, R.L., and Wells, R.R., 1956, Studies of the Snettisham Magnetite Deposit, Southeastern Alaska; Bureau of Mines Report of Investigations 5195, 41 p.

U.S. Bureau of Mines, 1995, Spatial Data Extracted from the Minerals Availability System/ Mineral Industry Location System (MAS/MILS); U.S. Bureau of Mines Special Publication 12-95, CDROM.

U.S. Geological Survey, 1990, Generalized Geologic Map of the Chandler Lake Quadrangle, North-Central Alaska; U.S. Geological Survey Miscellaneous Field Studies Map MF-2144-A.

U.S. Geological Survey, 1992, U.S. Geological Survey Emeritus; Written Communication, October 1992.

Vandel, J., 1993, Bureau of Mines Salt Lake City Research Center; Written Communication, December 1993 and May 1994.

Wedow, H., Jr., White, M.G., and Moxham, R.M., 1952, Interim Report on an Appraisal of the Uranium Possibilities of Alaska; U.S. Geological Survey Open-File Report 51, 123 p.

\section{Pumice}

Moxham, R.M., 1952, Pumice Deposits in the Alaska Peninsula-Cook Inlet Region; U.S. Geological Survey Open-File Report 52-103, 21 p., 5 sheets, scales 1:253,440, 1:95,040, and 1:950,400. 


\section{Quartz Crystal}

Myers, L., and Myers, M., 1999, The Epidote Crystals of Green Monster Mountain; Rock \& Gem, January 1999, P. 64-67.

U.S. Bureau of Mines, 1945, Proposed Investigation of Mineral Deposits on Alaska Peninsula and Aleutian Islands; Bureau of Mines Draft War Minerals Report 4503.

Williams, J.A., 1952, Denny's Gulch and Sawlog Creek - Magnetometer Survey; Alaska Territorial Department of Mines Prospect Evaluation PE-31-2, 28 p., 1 sheet, scale 1:2,400.

\section{Silica}

Barker, J.C., Still, J.C., Mowatt, T.C., and Mulligan, J.J., 1981, Critical and Strategic Minerals in Alaska: Cobalt, the Platinum-Group Metals, and Chromite; Bureau of Mines Information Circular 8869, 8 p., 1 sheet, scale 1:250,000.

Cobb, E.H., 1972, Metallic Mineral Resources Map of the Port Alexander Quadrangle, Alaska; U.S. Geological Survey Miscellaneous Field Studies Map MF-464, 1 sheet, scale 1:250,000.

Cobb, E.H., 1972, Metallic Mineral Resources Map of the Seldovia Quadrangle, Alaska; U.S. Geological Survey Miscellaneous Field Studies Map MF-397, 1 sheet, scale 1:250,000.

Cobb, E.H., 1972, Metallic Mineral Resources Map of the Sumdum Quadrangle, Alaska; U.S. Geological Survey Miscellaneous Field Studies Map MF-425, 1 sheet, scale 1:250,000.

Foley, J.Y., and Barker, J.C., 1985, Chromite Deposits Along the Border Ranges Fault, Southern Alaska. (In Two Parts.) 1. Field Investigations and Descriptions of Chromite Deposits; Bureau of Mines Information Circular 8990, $58 \mathrm{p}$.

Kaufman, A., 1958, Southeastern Alaska's Mineral Industry; Bureau of Mines Information Circular 7844, $37 \mathrm{p}$.

MacKevett, E.M., Jr., and Holloway, C.D., 1977, Map Summarizing Metalliferous and Selected Nonmetalliferous Mineral Deposits in the Eastern Part of Southern Alaska; U.S. Geological Survey Open-File Report 77-169-A, 99 p., 1 sheet, scale 1:1,000,000.

Rutledge, F.A., 1946, Exploration of Red Mountain Chromite Deposits, Kenai Peninsula, Alaska; Bureau of Mines Report of Investigations 3885, 26 p.

Sanford, R.S., 1944, Red Mountain Chromite Deposits, Kenai Peninsula, Alaska; Bureau of Mines War Minerals Report 191, 51 p.

Sanford, R.S., and Cole, J.W., 1941, Investigation of the Claim Point Chromite Deposits, Kenai Peninsula, Alaska; Bureau of Mines Report of Investigations 4419, 11 p.

Thorne, R.L., and Wells, R.R., 1956, Studies of the Snettisham Magnetite Deposit, Southeastern Alaska; Bureau of Mines Report of Investigations 5195, 41 p.

Wells, R.R., Sterling, F.T., Erspamer, E.G., and Stickney, W.A., 1957, Laboratory Concentration of Chromite Ores, Red Mountain District, Kenai Peninsula, Alaska; Bureau of Mines Report of Investigations 5377, $22 \mathrm{p}$. 


\section{Sulfur}

Barker, J.C., Still, J.C., Mowatt, T.C., and Mulligan, J.J., 1981, Critical and Strategic Minerals in Alaska: Cobalt, the Platinum-Group Metals, and Chromite; Bureau of Mines Information Circular 8869, 8 p., 1 sheet, scale 1:250,000.

Berg, H.C., and Cobb, E.H., 1967, Metalliferous Lode Deposits of Alaska; U.S. Geological Survey Bulletin $1246,254 \mathrm{p}$.

Clark, A.L., and Cobb, E.H., 1972, Metallic Mineral Resources Map of the Healy Quadrangle, Alaska; U.S. Geological Survey Miscellaneous Field Studies Map MF-394, 1 sheet, scale 1:250,000.

Cobb, E.H., 1972, Metallic Mineral Resources Map of the Kenai Quadrangle, Alaska; U.S. Geological Survey Miscellaneous Field Studies Map MF-377, 1 sheet, scale 1:250,000.

Cobb, E.H., 1972, Metallic Mineral Resources Map of the Port Moller Quadrangle, Alaska; U.S. Geological Survey Miscellaneous Field Studies Map MF-443, 1 sheet, scale 1:250,000.

Cobb, E.H., 1972, Metallic Mineral Resources Map of the Sumdum Quadrangle, Alaska; U.S. Geological Survey Miscellaneous Field Studies Map MF-425, 1 sheet, scale 1:250,000.

Condon, W.H., and Cass, J.T., 1958, Map of a Part of the Prince William Sound Area, Alaska, Showing Linear Geologic Features as Shown on Aerial Photographs; U.S. Geological Survey Miscellaneous Geologic Investigations Series Map I-273, 1 sheet, scale 1:125,000.

Grantz, A., 1956, Magnetite Deposits at Tuxedni Bay, Alaska; U.S. Geological Survey Bulletin 1024-D, $11 \mathrm{p}$.

Kaufman, A., 1958, Southeastern Alaska's Mineral Industry; Bureau of Mines Information Circular 7844, $37 \mathrm{p}$.

Kelley, K.D., Borden, J.C., Bailey, E.A., Fey, D.L., Motooka, J.M., and Roushey, B.H., 1991, Geochemically Anomalous Areas in the West-Central Part of the Howard Pass Quadrangle, National Petroleum Reserve, Alaska: Evidence for Sediment-Hosted Zn-Pb-Ag-Ba Mineralization; U.S. Geological Survey Bulletin 2041, p. 60-69.

MacKevett, E.M., Jr., and Holloway, C.D., 1977, Map Summarizing Metalliferous and Selected Nonmetalliferous Mineral Deposits in the Eastern Part of Southern Alaska; U.S. Geological Survey Open-File Report 77-169-A, 99 p., 1 sheet, scale 1:1,000,000.

Rutledge, F.A., 1953, Investigation of the Copper Bullion Claims, Rua Cove, Knight Island, Alaska; Bureau of Mines Report of Investigations 4986, 6 p.

Thorne, R.L., and Wells, R.R., 1956, Studies of the Snettisham Magnetite Deposit, Southeastern Alaska; Bureau of Mines Report of Investigations 5195, 41 p.

Tysdal, R.G., 1979, Mines, Prospects, and Occurrences Map of the Seward and Blying Sound Quadrangles, Alaska; U.S. Geological Survey Miscellaneous Field Studies Map MF-880-A, 2 sheets, scale $1: 250,000$.

\section{Wollastonite}

Barker, J.C., 1981, Mineral Investigations in the Porcupine River Drainage, Alaska; U.S. Bureau of Mines Open-File Report 27-81, 189 p. 
Barker, J.C., and Clautice, K.H., 1978, Mineral Reconnaissance of the Porcupine River Region: A Summary Report; U.S. Bureau of Mines Open-File Report 87-78, 20 p.

Cobb, E.H., 1973, Metallic Mineral Resources Map of the Craig Quadrangle, Alaska; U.S. Geological Survey Miscellaneous Field Studies Map MF-433, 1 sheet, scale 1:250,000.

Dover, J., 1997, Alaska Resource Data File-Coleen Quadrangle; U.S. Geological Survey Open-File Report 97-295, $39 \mathrm{p}$.

U.S. Bureau of Mines, 1995, Spatial Data Extracted from the Minerals Availability System/ Mineral Industry Location System (MAS/MILS); U.S. Bureau of Mines Special Publication 12-95, CDROM.

\title{
Zeolites
}

Hawkins, D.B., 1976, Commercial-Grade Mordenite Deposits of the Horn Mountains, South-Central Alaska; Alaska Division of Geological \& Geophysical Surveys Special Report 11, 11 p.

Hawkins, D.B., 1988, A Potential Economic Mordenite Deposit Talkeetna Mountains, Alaska; Occurrence, Properties, and Utilization of Natural Zeolites, August 12-16, 1985, p. 19-28.

Keith, T.E.C., Barnes, I., and Foster, H.L., 1980, Laumontite Occurrence in the Circle A-1 Quadrangle, Alaska; U.S. Geological Survey Cirular 823-B, p. B28-B29.

Madonna, James A., 1982, Clinoptilolite and Mordenite Deposits of Possible Economic Value at Iliamna Lake, Alaska; Alaska Division of Geological \& Geophysical Surveys Geologic Report 73, p. 1315 .

U.S. Bureau of Mines, 1945, Proposed Investigation of Mineral Deposits on Alaska Peninsula and Aleutian Islands; Draft War Minerals Report 4503.

\section{Zirconium}

Cobb, E.H., 1972, Metallic Mineral Resources Map of the Juneau Quadrangle, Alaska; U.S. Geological Survey Miscellaneous Field Studies Map MF-435, 1 sheet, scale 1:250,000.

Cobb, E.H., and Matson, N.A., Jr., 1972, Metallic Mineral Resources Map of the Valdez Quadrangle, Alaska; U.S. Geological Survey Miscellaneous Field Studies Map MF-438, 1 sheet, scale $1: 250,000$.

Lathram, E.H., Loney, R.A., Condon, W.H., and Berg, H.C., 1959, Progress Map of the Geology of the Juneau Quadrangle, Alaska; U.S. Geological Survey Miscellaneous Geologic Investigations Series Map I-303, 1 sheet, scale 1:250,000.

\section{QUARTER-MILLION QUADRANGLES}

\begin{abstract}
Ambler River
Anderson, E., 1945, Asbestos and Jade Occurrences in the Kobuk River Region, Alaska; Alaska Territorial Department of Miners Pamphlet 3-R, 48 p.
\end{abstract}


Anderson, E., 1947, Mineral Occurrences Other Than Gold Deposits in Northwest Alaska; Alaska Territorial Department of Mines Pamphlet 5-R, 48 p.

Bundtzen, T.K., Eakins, G.R., and Conwell, C.N., 1982 ,Review of Alaska's Mineral Resources; Alaska Division of Geological \& Geophysical Surveys and Alaska Department of Commerce and Economic Development.

Cobb, E.H., 1972, Metallic Mineral Resources Map of the Ambler River Quadrangle, Alaska; U.S. Geological Survey Miscellaneous Field Studies Map MF-454, 1 sheet, scale 1:250,000.

Degenhart, C.E., Griffis, R.J., McOuat, J.F., and Bigelow, C.G., 1978, Mineral Studies of the Western Brooks Range Performed Under Contract to the U.S. Bureau of Mines, Contract \#J0155089, Vol. 1; Bureau of Mines Open-File Report 103-78, 544 p., 11 sheets, scale 1:63,360.

Fernald, A.T., 1964, Surficial Geology of the Central Kobuk River Valley, Northwestern Alaska; U.S. Geological Survey Bulletin 1181-K, 31 p., 1 sheet, scale 1:250,000.

Fritts, C.E., 1970, Geology and Geochemistry of the Cosmos Hills, Ambler River and Shungnak Quadrangles, Alaska; Alaska Division of Mines and Geology Report 39, 69 p.

Heide, H.E., Wright, W.S., and Rutledge, F.A., 1944, Dahl Creek Asbestos Deposits, Kobuk River Region, Alaska; Bureau of Mines War Minerals Report 229, 6 p.

Heide, H.E., Wright, W.S., and Rutledge, F.A., 1949, Investigation of the Kobuk River Asbestos Deposits, Kobuk District, Northwestern Alaska; Bureau of Mines Report of Investigations 4414, 25 p.

Kurtak, J.M., Hicks, R.W., Werdon, M.B., Meyer, M.P., and Mull, C.G., 1995, Mineral Investigations in the Colville Mining District and Southern National Petroleum Reserve in Alaska; Bureau of Mines Open-File Report, 217 p., 1 sheet, scale 1:250,000.

Mayfield, C.F., and Grybeck, D., 1978, Mineral Occurrences and Resources Map of the Ambler River Quadrangle, Alaska; U.S. Geological Survey Open-File Map 78-120 I, 1 sheet, scale 1:250,000.

Nelson, S., 1997, Alaska Resource Data File-Ambler River Quadrangle; U.S. Geological Survey Open-File Report 97-856, 98 p.

Reed, I., 1931, Report on the Placer Deposits of the Upper Kobuk Goldfields; Alaska Territorial Department of Mines Unpublished Report, 33 p.

Schmidt, J.M., and Werdon, M.B., 1993, Clastic-hosted Stratiform, Vein/ Breccia and Disseminated Zn-PbAg Deposits of the Northwestern Brooks Range, Alaska: Are They Different Expressions of Dewatering of the Same Source Basin? [abs.]; Geological Society of America, Abstracts with Programs, v. 24, p. 143.

Schmidt, Jeanine M., 1997, Shale-Hosted Zn-Pb-Ag and Barite Deposits of Alaska; Economic Geology Monograph 9, $31 \mathrm{p}$.

Smith, P.S, and Mertie, J.B., Jr., 1930, Geology and Mineral Resources of Northwestern Alaska; U.S. Geological Survey Bulletin 815, 315 p.

Smith, P.S., 1913, The Noatak-Kobuk Region, Alaska; U.S. Geological Survey Bulletin 536, 157 p.

Smith, P.S., and Eakin, H.M., 1911, The Shungnak Region, Kobuk Valley; U.S. Geological Survey Bulletin 480, 25 p. 


\section{Anchorage}

Alaska Department of Revenue, 1982, Mine License Application.

Alaska Department of Revenue, 1983, Mine License Application.

Alaska Department of Revenue, 1984, Mine License Application.

Bundtzen, T.K., and Smith, T.E., 1982, Alaska's Industrial Minerals; Alaska Geographic, p. 64-73.

Cobb, E.H., 1972, Metallic Mineral Resources Map of the Anchorage Quadrangle, Alaska; U.S. Geological Survey Miscellaneous Field Studies Map MF-409, 1 sheet, scale 1:250,000.

Detterman, R.L., Plafker, G., Tysdal, R.G., and Hudson, T., 1976, Geology and Surface Features Along Part of the Talkeetna Segment of the Castle Mountain-Caribou Fault System, Alaska; U.S. Geological Survey Miscellaneous Field Studies Map MF-738, 1 sheet, scale 1:63,360.

Hawkins, D.B., 1976, Commercial-Grade Mordenite Deposits of the Horn Mountains, South-Central Alaska; Alaska Division of Geological \& Geophysical Surveys Special Report 11, 11 p.

Jasper, M.W., 1953, J. Fabian and D. Moore Clay Deposit (Little Susitna River); Alaska Territorial Department of Mines Prospect Evaluation PE-85-18, 1 p.

Jasper, M.W., and Mihelich, M., 1961, Permanente Cement Limestone (East Fork Kings River); Alaska Territorial Department of Mines Prospect Evaluation PE-85-22, 17 p., 2 sheets, scale 1:63,360.

Mulligan, J.J., 1974, Mineral Resources of the Trans-Alaska Pipeline Corridor; Bureau of Mines Information Circular 8626, 24 p., 9 sheets, scale 1:190,080.

U.S. Department of Labor, Mine Safety and Health Administration, 1985, Mine Safety and Health Examinations, 1975-1985.

\section{Arctic}

Barker, J.C., 1978, Mineral Investigations of Certain Lands in the Eastern Brooks Range, 1978: A Summary Report; Bureau of Mines Open-File Report 63-78, 25 p.

Cobb, E.H., Mayfield, C.F., Brosge, W.P., 1981, Summaries of Data on and Lists of References to Metallic and Selected Non-Metallic Mineral Occurrences in Eleven Quadrangles in Northern Alaska-Summaries of Data to January 1, 1981; U.S. Geological Survey Open-File Report 81-767, 40 p.

Dover, J.H., 1997, Alaska Resource Data File-Arctic Quadrangle; U.S. Geological Survey Open-File Report 97-292, 19 p.

\section{Baird Mountains}

Degenhart, C.E., Griffis, R.J., McOuat, J.F., and Bigelow, C.G., 1978, Mineral Studies of the Western Brooks Range Performed Under Contract to the U.S. Bureau of Mines, Contract \#J0155089, Vol. 1; Bureau of Mines Open-File Report 103-78, 544 p., 11 sheets, scale 1:63,360.

Grybeck, D.J., 1977, Map Showing Known Mineral Deposits of the Brooks Range, Alaska; U.S. Geological Survey Open-File Report 77-166-C, 45 p., 1 sheet, scale 1:1,000,000. 


\section{Beechey Point}

Mulligan, J.J., 1974, Mineral Resources of the Trans-Alaska Pipeline Corridor; Bureau of Mines Information Circular 8626, 24 p., 9 sheets, scale 1:190,080.

Rawlinson, S.E., 1990, Surficial Geology and Morphology of the Alaskan Central Arctic Coastal Plain; Alaska Division of Geological \& Geophysical Surveys Report Of Investigations 93-1, 172 p., 6 sheets, scale 1:63,360.

U.S. Department of Labor, Mine Safety and Health Administration, 1985, Mine Safety and Health Examinations, 1975-1985.

\section{Bendeleben}

Anderson, E., 1943, Pargon Mountain Muscovite Prospect (Seward Peninsula); Alaska Territorial Department of Mines Mineral Investigations MI-44-1, 9 p., 2 maps.

Cobb, E.H., 1972, Metallic Mineral Resources Map of the Bendeleben Quadrangle, Alaska; U.S. Geological Survey Miscellaneous Field Studies Map MF-417, 1 sheet, scale 1:250,000.

Cobb, E.H., 1975, Summary of References to Mineral Occurrences (Other Than Mineral Fuels and Construction Materials) in the Bendeleben Quadrangle, Alaska; U.S. Geological Survey Open-File Report 75-429, 123 p.

Jones, D.A., 1953, Foster Lead-Silver Prospect (Seward Peninsula); Alaska Territorial Department of Mines Prospect Evaluation PE-44-1, 14 p., 3 maps.

Sandvik, P.O., 1956, Mineral Investigation of a Radioactive Anomaly in the Candle Area; Alaska Territorial Department of Mines Mineral Investigations MI-44-2, 6 p., 1 map.

\section{Bering Glacier}

Cobb, E.H., 1972, Metallic Mineral Resources Map of the Bering Glacier Quadrangle, Alaska; U.S. Geological Survey Miscellaneous Field Studies Map MF-373, 1 sheet, scale 1:250,000.

Cobb, E.H., 1973, Placer Deposits of Alaska; U.S. Geological Survey Bulletin 1374, 213 p., 1 sheet.

MacKevett, E.M., Jr., and Holloway, C.D., 1977, Map Summarizing Metalliferous and Selected Nonmetalliferous Mineral Deposits in the Eastern Part of Southern Alaska; U.S. Geological Survey Open-File Report 77-169A, 99 p., 1 sheet, scale 1:1,000,000.

\section{Bethel}

U.S. Department of Labor, Mine Safety and Health Administration, 1985, Mine Safety and Health Examinations, 1975-1985.

\section{Bettles}

Campbell, L.J., 1995, Alaska’s Mineral Industry Today; Alaska Geographic, vol. 9, p. 31-65. 
Cobb, E.H., 1972, Metallic Mineral Resources Map of the Bettles Quadrangle, Alaska; U.S. Geological Survey Miscellaneous Field Studies Map MF-387, 1 sheet, scale 1:250,000.

Foley, J.Y., and McDermott, M.M., 1983, Podiform Chromite Occurrences in the Caribou Mountain and Lower Kanuti River Areas, Central Alaska. Part I: Reconnaissance Investigations; Bureau of Mines Information Circular 8915, 27 p.

Mulligan, J.J., 1974, Mineral Resources of the Trans-Alaska Pipeline Corridor; Bureau of Mines Information Circular 8626, 24 p., 9 sheets, scale 1:190,080.

\section{Big Delta}

Alaska Department of Revenue, 1982, Mine License Application.

Cobb, E.H., 1972, Metallic Mineral Resources Map of the Big Delta Quadrangle, Alaska; U.S. Geological Survey Miscellaneous Field Studies Map MF-388, 1 sheet, scale 1:250,000.

Saunders, R.H., 1958, Coben Graphite Prospect (French Creek); Alaska Territorial Department of Mines Prospect Evaluation PE-59-2, 2 p.

U.S. Department of Labor, Mine Safety and Health Administration, 1985, Mine Safety and Health Examinations, 1975-1985.

\section{Bradfield Canal}

Alaska Division of Geological and Geophysical Surveys, 1961, Paul Pieper Claims, North Bradfield River; Alaska Territorial Department of Mines Miscellaneous Report MR-118-3.

Berg, H.C., Decker, J.E., and Abramson, B.S., 1981, Metallic Mineral Deposits of Southeastern Alaska; U.S. Geological Survey Open-File Report 81-122, 145 p., 1 sheet, scale 1:1,000,000.

Cobb, E.H., 1972, Metallic Mineral Resources Map of the Dixon Entrance Quadrangle, Alaska; U.S. Geological Survey Miscellaneous Field Studies Map MF-434, 1 sheet, scale 1:250,000.

Cobb, E.H., 1972, Metallic Mineral Resources Map of the Petersburg Quadrangle, Alaska; U.S. Geological Survey Miscellaneous Field Studies Map MF-415, 1 sheet, scale 1:250,000.

MacKevett, E.M., Jr., and Blake, M.C., Jr., 1963, Geology of the North Bradfield River Iron Prospect, Southeastern Alaska; U.S. Geological Survey Bulletin 1108-D, 21 p., 1 sheet, scale 1:12,000.

U.S. Department of Labor, Mine Safety and Health Administration, 1985, Mine Safety and Health Examinations, 1975-1985.

\section{Candle}

Bundtzen, T.K., Eakins, G.R., and Conwell, C.N., 1982, Review of Alaska's Mineral Resources; Alaska Division of Geological \& Geophysical Surveys and Alaska Department of Commerce and Economic Development.

Berg, H.C., and Cobb, E.H., 1967, Metalliferous Lode Deposits of Alaska; U.S. Geological Survey Bulletin $1246,254 \mathrm{p}$. 
Cass, J.T., 1959, Reconnaissance Geologic Map of the Candle Quadrangle, Alaska; U.S. Geological Survey Miscellaneous Geologic Investigations Series Map I-287, 1 sheet, scale 1:250,000.

Cobb, E.H., 1972, Metallic Mineral Resources Map of the Candle Quadrangle, Alaska; U.S. Geological Survey Miscellaneous Field Studies Map MF-389, 1 sheet, scale 1:250,000.

Hudson, T.L., Miller, M.L., and Peckthorn, W.J., 1977, Map Showing Metalliferous and Selected Nonmetalliferous Mineral Deposits, Seward Peninsula, Alaska; U.S. Geological Survey Open-File Report 77-796-B, 46 p., 1 sheet, scale 1:1,000,000.

\section{Chandalar}

Brosge, W.P., and Reiser, H.N., 1964, Geologic Map and Section of the Chandalar Quadrangle, Alaska; U.S. Geological Survey Miscellaneous Geologic Investigations Series Map I-375, 1 sheet, scale $1: 250,000$.

Cobb, E.H., 1972, Metallic Mineral Resources Map of the Chandalar Quadrangle, Alaska; U.S. Geological Survey Miscellaneous Field Studies Map MF-457, 1 sheet, scale 1:250,000.

Mulligan, J.J., 1974, Mineral Resources of the Trans-Alaska Pipeline Corridor; Bureau of Mines Information Circular 8626, 24 p., 9 sheets, scale 1:190,080.

Williams, J.A., 1952, Denny's Gulch and Sawlog Creek - Magnetometer Survey; Alaska Territorial Department of Mines Prospect Evaluation PE-31-2, 28 p., 1 sheet, scale 1:2,400.

\section{Chandler Lake}

Barnwell, C.E., 1990, Arctic Slope Consulting Engineers; Written Communication.

Barnwell, C.E., Simpson, S., and Church, S.E., 1989, Analytical Results and Sample Locality Maps of Stream-Sediment and Rock Samples from the Cobblestone Creek Area, Southeastern Chandler Lake Quadrangle, Alaska; U.S. Geological Survey Open-File Report 89-540, 26 p.

Cobb, E.H., 1975, Summary of References to Mineral Occurrences (other than mineral fuels and construction materials) in Northern Alaska; U.S. Geological Survey Open-File Report 75-628, 106 p.

Cobb, E.H., Mayfield, C.F., Brosge, W.P., 1981, Summaries of Data on and Lists of References to Metallic and Selected Non-Metallic Mineral Occurrences in Eleven Quadrangles in Northern Alaska-Summaries of Data to January 1, 1981; U.S. Geological Survey Open-File Report 81-767, 40 p.

Duttweiler, K.A., 1986, Sulfide Occurrences in the Itkillik River Region, Southeast Chandler Lake Quadrangle, Brooks Range; U.S. Geological Survey Circular 978, p 10-13.

Force, E.R., and Cannon, W.F., 1988, Depositional Model for Shallow-Marine Manganese Deposits Around Black Shale Basins; Economic Geology, v. 83, p. 93-117.

Govier, R.D., 1994, Bureau of Mines, Research Center, Salt Lake City, Utah; Written Communication.

Grybeck, D.J., 1977, Map Showing Known Mineral Deposits of the Brooks Range, Alaska; U.S. Geological Survey Open-File Report 77-166-C, 45 p., 1 sheet, scale 1:1,000,000.

Harben, P.W., 1984, Geology of the Nonmetallics; Metal Bulletin Inc., New York, 392 p. 
Heiner, L.E., and Wolff, E.N., 1968, Mineral Resources of Northern Alaska, Final Report Submitted to the North Commission; Mineral Industry Research Laboratory, University of Alaska, Report 16, 306 p., 3 sheets, scales 1:1,000,000 and 1:5,000,000.

Kelley, J.S., 1982, Phosphate and Whole Rock Chemical Analyses from Upper Paleozoic and Lower Mexozoic Strata in the Chandler Lake and Killik River Quadrangles, Alaska; U.S. Geological Survey Unpublished Report.

Kelley, K.D., 1997, Alaska Resource Data File-Chandler Lake Quadrangle; U.S. Geological Survey OpenFile Report 97-265, 24 p.

Kurtak, J.M., Hicks, R.W., Werdon, M.B., Meyer, M.P., and Mull, C.G., 1995, Mineral Investigations in the Colville Mining District and Southern National Petroleum Reserve in Alaska; Bureau of Mines Open-File Report, 217 p., 1 sheet, scale 1:250,000.

LeFond, S.J., ed., 1983, Industrial Minerals and Rocks; Society of Mining Engineers, 2 vol., 1433 p.

Meyer, M.P., 1994, Analytical Results from U.S. Bureau of Mines Investigations in the Colville Mining District, Alaska; U.S. Bureau of Mines Open-File Report 34-94, 137 p.

Patton, W.W., Jr., and Matzko, J.J., 1959, Phosphate Deposits in Northern Alaska; U.S. Geological Survey Professional Paper 302-A, 17 p.

Patton, W.W., Jr., and Tailleur, I.L., 1964, Geology of the Upper Killik-Itkillik Region, Alaska; U.S. Geological Survey Professional Paper 303-G, 90 p.

Perkins, W, Jr., 1994, Simplot Co., Afton, Wyoming, Written Communication.

U.S. Geological Survey, 1990, Generalized Geologic Map of the Chandler Lake Quadrangle, North-Central Alaska; U.S. Geological Survey Miscellaneous Field Studies Map MF-2144-A.

U.S. Geological Survey, 1993, U.S. Geological Survey, Anchorage, Alaska; Written Communication.

Vandel, J., 1993, Bureau of Mines Salt Lake City Research Center; Written Communication.

Wedow, H., Jr., White, M.G., and Moxham, R.M., 1952, Interim Report on an Appraisal of the Uranium Possibilities of Alaska; U.S. Geological Survey Open-File Report 51, 123 p.

\section{Charley River}

Alaska Department of Revenue, 1983, Mine License Application.

Cobb, E.H., 1972, Metallic Mineral Resources Map of the Charley River Quadrangle, Alaska; U.S. Geological Survey Miscellaneous Field Studies Map MF-390, 1 sheet, scale 1:250,000.

Williams, J.A., 1951, Radiometric Investigations, Connel Property (28 Mile); Alaska Territorial Department of Mines Prospect Evaluation PE-51-1, 10 p. 


\section{Chignik}

Bundtzen, T.K., Eakins, G.R., and Conwell, C.N., 1982, Review of Alaska's Mineral Resources; Alaska Division of Geological \& Geophysical Surveys and Alaska Department of Commerce and Economic Development.

Cobb, E.H., 1972, Metallic Mineral Resources Map of the Bethel Quadrangle, Alaska; U.S. Geological Survey Miscellaneous Field Studies Map MF-455, 1 sheet, scale 1:250,000.

Cobb, E.H., 1972, Placer Deposits of Alaska; U.S. Geological Survey Open-File Report 72-71, 132 p.

MacKevett, E.M., Jr., and Holloway, C.D., 1977, Map Showing Metalliferous Mineral Deposits in the Western Part of Southern Alaska; U.S. Geological Survey Open-File Report 77-169-F, 39 p., 1 sheet, scale 1:1,000,000.

Reed, B.L., and Lanphere, M.A., 1972, Generalized Geologic Map of the Alaska Aleutian Range Batholith Showing Potassium-Argon Ages of the Plutonic Rocks; U.S. Geological Survey Miscellaneous Field Studies Map MF-372, 2 sheets, scale 1:1,000,000.

\section{Christian}

Barker, J.C., and Clautice, K.H., 1978, Mineral Reconnaissance of the Porcupine River Region: A Summary Report; U.S. Bureau of Mines Open File Report 87-78, 20 p.

Berg, H.C., and Cobb, E.H., 1967, Metalliferous Lode Deposits of Alaska; U.S. Geological Survey Bulletin $1246,254 \mathrm{p}$.

Brosge, W.P., and Reiser, H.N., 1962, Preliminary Geologic Map of the Christian Quad, Alaska; U.S. Geological Survey Open-File Report 62-15, 2 sheets, scale 1:250,000.

Dover, J., 1997, Alaska Resource Data File-Christian Quadrangle; U.S. Geological Survey Open-File Report 97-294, 6 p.

Enns, S., and Findley, A., 1977, Venetie Indian Reservation; Unpublished British Petroleum Mineral Survey $54 \mathrm{p}$.

Foley, J.Y., Barker, J.C., and Brown, L.B., 1985, Critical and Strategic Minerals Investigations in Alaska: Chromium; U.S. Bureau of Mines Open File Report 97-85, 54 p.

Foley, J.Y., Burns, L.E., Schneider, C.L., and Forbes, R.B., 1989, Preliminary Report of Platinum Group Element Occurrences in Alaska; Alaska Department of Geological and Geophysical Surveys Public Data File 89-20, 33 p., scale 1:2,500,000.

Hawley, C.C., and Garcia, G., 1976, Mineral Appraisal and Geologic Background of the Venetie Native Lands; Unpublished Bureau of Indian Affairs Contract Report No. 6E00-0102598.

U.S. Bureau of Mines, 1995, Spatial Data Extracted from the Minerals Availability System/ Mineral Industry Location System (MAS/MILS); U.S. Bureau of Mines Special Publication 12-95, CDROM.

\section{Circle}

Alaska Department of Revenue, 1985, Mine License Application. 
Bundtzen, T.K., Eakins, G.R., and Conwell, C.N., 1982, Review of Alaska's Mineral Resources; Alaska Division of Geological \& Geophysical Surveys and Alaska Department of Commerce and Economic Development.

Carnes, R.D., 1976, Active Alaskan Placer Operations, 1975; Bureau of Mines Open-File Report 98-76.

Cobb, E.H., 1972, Metallic Mineral Resources Map of the Circle Quadrangle, Alaska; U.S. Geological Survey Miscellaneous Field Studies Map MF-391, 1 sheet, scale 1:250,000.

Forbes, R.B., Kline, J.T., and Clough, A.H., 1987, A Preliminary Evaluation of Alluvial Diamond Discoveries in Placer Gravels of Crooked Creek, Circle District, Alaska; Alaska Division of Geological \& Geophysical Surveys Report Of Investigations RI 87-1, 26 p.

Keith, T.E.C., Barnes, I., and Foster, H.L., 1980, Laumontite Occurrence in the Circle A-1 Quadrangle, Alaska; U.S. Geological Survey Circular 823-B, p. B28-B29.

\section{Cold Bay}

Cobb, E.H., 1972, Metallic Mineral Resources Map of the Cold Bay Quadrangle, Alaska; U.S. Geological Survey Miscellaneous Field Studies Map MF-441, 1 sheet, scale 1:250,000.

\section{Coleen}

Barker, J.C., 1981, Mineral Investigations in the Porcupine River Drainage, Alaska; U.S. Bureau of Mines Open-File Report 27-81, 189 p.

Barker, J.C., 1978, Mineral Investigations of Certain Lands in the Eastern Brooks Range, 1978: A Summary Report; Bureau of Mines Open-File Report 63-78, 25 p.

Barker, J.C., and Clautice, K.H., 1978, Mineral Reconnaissance of the Porcupine River Region: A Summary Report; U.S. Bureau of Mines Open File Report 87-78, 20 p.

Brosge', W.R., and Reiser, H.N., 1968, Geochemical Maps of Granitic Rocks, Coleen and Table Mountain Quadrangles, Alaska; U.S. Geological Survey Open-File Report 323, Scale 1:250,000.

Brosge', W.R., and Reiser, H.N., 1976, Preliminary Geologic and Mineral Resource Maps (excluding petroleum), Arctic National Wildlife Range, Alaska; U.S. Geological Survey Open-File Report 76-539, 4 p., scale 1:500,000.

Brosge', W.R., and Reiser, H.N., 1969, Preliminary Geologic Map of the Coleen Quadrangle, Alaska; U.S. Geological Survey Open-File Report 69-25, Scale 1:250,000.

Cobb, E.H., 1972, Metallic Mineral Resources Map of the Coleen Quadrangle, Alaska; U.S. Geological Survey Miscellaneous Field Studies Map MF-403, 1 sheet, scale 1:250,000.

Dover, J., 1997, Alaska Resource Data File-Colleen Quadrangle; U.S. Geological Survey Open-File Report 97-295, 39 p.

Grybeck, D.J., 1977, Map Showing Known Mineral Deposits of the Brooks Range, Alaska; U.S.

Geological Survey Open-File Report 77-166-C, 45 p., 1 sheet, scale 1:1,000,000. 
U.S. Bureau of Mines, 1995, Spatial Data Extracted from the Minerals Availability System/ Mineral Industry Location System (MAS/MILS); U.S. Bureau of Mines Special Publication 12-95, CDROM.

White, M.G., 1952, Reconnaissance for Radioactive Deposits Along the Upper Porcupine and Lower Coleen Rivers, Northeastern Alaska; U.S. Geological Survey Circular 185, 13 p.

\section{Cordova}

Alaska Department of Revenue, 1982, Mine License Application.

U.S. Department of Labor, Mine Safety and Health Administration, 1985, Mine Safety and Health Examinations, 1975-1985.

\section{Craig}

Alaska Department of Revenue, 1982, Mine License Application.

Berg, H.C., 1984, Regional Geologic Summary, Metallogenesis and Mineral Resources of Southeastern Alaska; U.S. Geological Survey Open-File Report 84-572, 298 p.

Berg, H.C., and Cobb, E.H., 1967, Metalliferous Lode Deposits of Alaska; U.S. Geological Survey Bulletin $1246,254 \mathrm{p}$.

Berg, H.C., Decker, J.E., and Abramson, B.S., 1981, Metallic Mineral Deposits of Southeastern Alaska; U.S. Geological Survey Open-File Report 81-122, 145 p., 1 sheet, scale 1:1,000,000.

Bundtzen, T.K., Eakins, G.R., and Conwell, C.N., 1982, Review of Alaska's Mineral Resources; Alaska Division of Geological \& Geophysical Survey and Alaska Department of Commerce and Economic Development.

Cobb, E.H., 1973, Metallic Mineral Resources Map of the Craig Quadrangle, Alaska; U.S. Geological Survey Miscellaneous Field Studies Map MF-433, 1 sheet, scale 1:250,000.

Erickson, A.W., 1948, Investigation of the Tolstoi Mountain Iron Deposits, Kasaan Peninsula, Prince of Wales Island, Southeastern Alaska; Bureau of Mines Report of Investigations 4373, 5 p.

Glover, A.E., 1951, Union Bay Reconnaissance (Cleveland Peninsula); Alaska Territorial Department of Mines Mineral Investigation MI-119-2, 4 p.

Gonnason Exploration Co., 1963, Magnetometer Survey Jumbo Mine (Prince of Wales Island); Alaska Territorial Department of Mines Miscellaneous Report MR-119-4, 5 p., 2 maps.

Herreid, G., Bundtzen, T.K., and Turner, K.L., 1978, Geology and Geochemistry of the Craig A-2 Quadrangle and Vicinity, Prince of Wales Island, Southeastern Alaska; Alaska Division of Geological and Geophysical Surveys Geologic Report 48, 49 p.

Hodge, E.T., 1944, Southeastern Coastal Alaska Limestone Terrain; Alaska Territorial Department of Mines Miscellaneous Report MR-191-8, 29 p., 2 sheets, scale 1:1,900,800.

Holdsworth, P.R., 1954, Investigation of Claim Staking (Union Bay Area); Alaska Territorial Department of Mines Prospect Evaluation PE-119-23. 
Holt, S.P., and Erickson, A.E., 1945, Tolstoi Mountain, Kasaan Peninsula, Prince of Wales Island, Southeastern Alaska; Bureau of Mines War Minerals Report 361, 6 p.

Holt, S.P., Thorne, R.L., Erickson, A.R., and Tolonen, A.W., 1944, Poor Man Iron Deposit, Kasaan Peninsula, Prince of Wales Island, Southeastern Alaska; Bureau of Mines War Minerals Report 227, $27 \mathrm{p}$.

Holt, S.P., Wright, W.S., and Fosse, E.L., 1945, Jumbo Basin, Prince of Wales Island, Southeastern Alaska--Iron, Copper; Bureau of Mines War Minerals Report 447, 13 p.

Howard, A.L., 1935, Rush and Brown-Salt Chuck (Alaska Gold and Metals Co., Kasaan Bay); Alaska Territorial Department of Mines Miscellaneous Report MR-119-2, 8 p.

Howard, A.L., 1935, Salt Chuck Mine (Alaska Gold and Metals Co., Kasaan Bay); Alaska Territorial Department of Mines Miscellaneous Report MR-119-2A, 14 p.

Myers, L., and Myers, M., 1999, The Epidote Crystals of Green Monster Mountain; Rock \& Gem, p. 64-67.

Noel, G.A., 1963, Peacock Fraction; Alaska Territorial Department of Mines Miscellaneous Report MR$119-5,6 \mathrm{p}$.

Nokleberg, W.J., Plafker, G., and Wilson, F.H., 1994, Geology of Southcentral Alaska; Boulder, Colorado, Geological Society of America, Geology of North America, v. G1, p. 311-366.

Pillmore, C.L., and McQueen, K., 1956, Map of Salt Chuck Area, Prince of Wales Island, Alaska; Showing Linear Features as Seen on Aerial Photographs; U.S. Geological Survey Miscellaneous Geologic Investigations Series Map I-230, 1 sheet, scale 1:12,000.

Roehm, J.C., 1938, Copper Came Group (Karta Bay); Alaska Territorial Department of Mines Prospect Evaluation PE119-10, $2 \mathrm{p}$.

Roehm, J.C., 1938, Copper Center Prospect (Kasaan Peninsula); Alaska Territorial Department of Mines Prospect Evaluation PE-119-9, 2 p.

Roehm, J.C., 1938, Mucker's Dream Group (Windfall Bay); Alaska Territorial Department of Mines Prospect Evaluation PE-119-14, 3 p.

Roehm, J.C., 1938, Shepard Group (Kasaan Peninsula); Alaska Territorial Department of Mines Prospect Evaluation PE-119-11, 2 p.

Roehm, J.C., 1938, Venus Group (Karta Bay); Alaska Territorial Department of Mines Prospect Evaluation PE-119-12, 2 p.

Roehm, J.C., 1941, Iron Capor Mahoney Prospect (Tolstoi Bay); Alaska Territorial Department of Mines Prospect Evaluation PE-119-19, 2 p.

Roehm, J.C., 1946, Some High Calcium Limestone Deposits in Southeastern Alaska; Alaska Territorial Department of Mines Pamphlet 6, 20 p.

Ruckmick, J.C., and Noble, J.A., 1959, Origin of the Ultramafic Complex at Union Bay, Southeastern Alaska; Geological Society of America Bulletin 5908, 36 p.

Schmidt, Jeanine M., 1997, Shale-Hosted Zn-Pb-Ag and Barite Deposits of Alaska; Economic Geology Monograph 9, $31 \mathrm{p}$. 
Shepard, J.G., 1926, Ketchikan District Properties; Alaska Territorial Department of Mines Miscellaneous Report MR-191-1A, 18 p.

U.S. Bureau of Mines, 1945, Mount Andrew Iron Deposit, Kasaan Peninsula, Prince of Wales Island, Southeastern Alaska; Bureau of Mines Draft Preliminary War Minerals Report 4504.

U.S. Bureau of Mines, 1945, Rush and Brown Mine, Kasaan Bay, Prince of Wales Island, Southeastern Alaska; Bureau of Mines War Minerals Report 455, 9 p.

U.S. Bureau of Mines, 1945, Salt Chuck Mine, Kasaan Peninsula, Prince of Wales Island, Southeastern Alaska--Copper, Palladium; Bureau of Mines War Minerals Report 423, 17 p.

U.S. Bureau of Mines, 1985, Unpublished data, 1970-1985.

U.S. Department of Labor, Mine Safety and Health Administration, 1985, Mine Safety and Health Examinations, 1975-1985.

Warner, L.A., Goddard, E.N., and others, 1961, Iron and Copper Deposits of Kasaan Peninsula, Prince of Wales Island, Southeastern Alaska; U.S. Geological Survey Bulletin 1090, 136 p., 28 sheets, scale $1: 63,360$.

Wilcox, H.G., 1938, Kasaan Gold Property (Twelve Mile Arm, Harris Creek); Alaska Territorial Department of Mines Prospect Evaluation PE-119-5, 2 p.

Wright, W.S., and Fosse, E.L., 1946, Exploration of the Jumbo Basin Iron Deposit, Prince of Wales Island, Southeastern Alaska; Bureau of Mines Report of Investigations 3952, 9 p.

\section{De Long Mountains}

Plahuta, J.T., 1978, Geologic Map and Cross Sections of the Red Dog Prospect, DeLong Mountains, Northwestern Alaska; Bureau of Mines Open-File Report 65-78.

Tailleur, I.L., Eberlein, G.D., and Wehr, R., 1970, Lead-Zinc and Barite-Bearing Samples From the Western Brooks Range, Alaska. With a Section on Petrography and Mineralogy; U.S. Geological Survey Open-File Report 70-319, 16 p.

\section{Demarcation Point}

Barker, J.C., 1978, Mineral Investigations of Certain Lands in the Eastern Brooks Range, 1978: A Summary Report; Bureau of Mines Open-File Report 63-78, 25 p.

Bird, K.J., and Molenaar, C.M., 1987, Chapter 5, Stratigraphy (in) Bird, K.J., and Magoon, L.B. (eds.), Petroleum Geology of the Northern Part of the Arctic Wildlife Refuge, Northeastern Alaska; U.S. Geological Survey Bulletin 1778, p. 37 to 59 .

Brosge', W.R., and Reiser, H.N., 1976, Preliminary Geologic and Mineral Resource Maps (excluding petroleum), Arctic National Wildlife Range, Alaska; U.S. Geological Survey Open-File Report 76-539, 4 p., scale 1:500,000.

Cobb, E.H., 1972, Metallic Mineral Resources Map of the Mt. Michelson Quadrangle, Alaska; U.S. Geological Survey Miscellaneous Field Studies Map MF-462, 1 sheet, scale 1:250,000. 
Cobb, E.H., 1975, Summary of References to Mineral Occurrences (other than mineral fuels and construction materials) in Northern Alaska; U.S. Geological Survey Open-File Report 75-628, 106 p.

Cobb, E.H., Mayfield, C.F., Brosge, W.P., 1981, Summaries of Data on and Lists of References to Metallic and Selected Non-Metallic Mineral Occurrences in Eleven Quadrangles in Northern Alaska-Summaries of Data to January 1, 1981; U.S. Geological Survey Open-File Report 81-767, 40 p.

Detterman, R.L., Reiser, H.N., Brosge', W.P., and Dutro, J.T., Jr., 1975, Post-Carboniferous Stratigraphy, Northeastern Alaska; U.S. Geological Survey Professional Paper 886, 46 p.

Grybeck, D.J., 1977, Map Showing Known Mineral Deposits of the Brooks Range, Alaska; U.S. Geological Survey Open-File Report 77-166-C, 45 p., 1 sheet, scale 1:1,000,000.

Kelley, J.S., 1996, Alaska Resource Data File-Demarcation Point Quadrangle; U.S. Geological Survey Open-File Report 96-678, 14 p.

Tourtelot, H.A., and Tailleur, I.L., 1971, The Shublik Formation and Adjacent Strata in Northwestern Alaska; U.S. Geological Survey Open-File Report 71-284, 62 p.

\section{Dillingham}

Berg, H.C., and Cobb, E.H., 1967, Metalliferous Lode Deposits of Alaska; U.S. Geological Survey Bulletin $1246,254 \mathrm{p}$.

Cobb, E.H., 1972, Metallic Mineral Resources Map of the Dillingham Quadrangle, Alaska; U.S. Geological Survey Miscellaneous Field Studies Map MF-375, 1 sheet, scale 1:250,000.

Eberlein, G.D., Chapman, R.M., Foster, H.L., and Gassaway, J.S., 1977, Map and Table Describing Known Metalliferous and Selected Nonmetalliferous Mineral Deposits in Central Alaska; U.S. Geological Survey Open-File Report 77-168-D, 131 p., 1 sheet, scale 1:1,000,000.

Humble Oil and Refining Co., 1959, Kemuk Mountain Iron Ore Prospect; Alaska Territorial Department of Mines Miscellaneous Report MR-102-1, 12 p.

\section{Dixon Entrance}

Alaska Economic Report (Anchorage), 1979, Alaska Mineral Exploration Increasing, but Land Uncertainties Cloud Future; Alaska Economic Report May 15, 1979.

Barker, J.C., and Warner, J.D., 1988, USBM Inventories Alaskan Rare Earths Deposits; Engineering \& Mining Journal, p. $42-43$

Bundtzen, T.K., Eakins, G.R., and Conwell, C.N., 1982, Review of Alaska's Mineral Resources; Alaska Division of Geological \& Geophysical Surveys and Alaska Department of Commerce and Economic Development.

Bundtzen, T.K., and Smith, T.E., 1982, Alaska's Industrial Minerals; Alaska Geographic, p. 64-73.

Campbell, L.J., 1995, Alaska's Mineral Industry Today, Alaska Geographic, p. 31-65.

Cobb, E.H., 1972, Metallic Mineral Resources Map of the Dixon Entrance Quadrangle, Alaska; U.S. Geological Survey Miscellaneous Field Studies Map MF-434, 1 sheet, scale 1:250,000. 
Cobb, E.H., 1973, Metallic Mineral Resources Map of the Craig Quadrangle, Alaska; U.S. Geological Survey Miscellaneous Field Studies Map MF-433, 1 sheet, scale 1:250,000.

Eakins, G.R., 1970, An Experiment in Geobotanical Prospecting for Uranium, Bokan Mountain Area, Southeastern Alaska; Alaska Division of Geological \& Geophysical Surveys Geologic Report 41, $51 \mathrm{p}$.

Eakins, G.R., and Forbes, R.B., 1976, Investigation of Alaska's Uranium Potential; Alaska Division of Geological \& Geophysical Surveys Geologic Report 12, 372 p., 5 sheets, scale 1:1,000,000.

Elmendorf, W.J., 1920, Lime Point Barite Deposit (Prince of Wales Island); Alaska Territorial Department of Mines Miscellaneous Report MR-119-1, 9 p.

Fowler, H.M., 1948, Lime Point Barite Occurrence (Prince of Wales Island); Alaska Territorial Department of Mines Prospect Evaluation PE-119-21, 4 p.

Glover, A.E., 1954, Tah Bay Reconnaissance (Prince of Wales Island); Alaska Territorial Department of Mines Mineral Investigation MI-121-1, 3 p.

Gray, J.E., Sanzolone, R.F., 1996, Environmental Studies of Mineral Deposits in Alaska; U.S. Geological Survey Bulletin 2156, $39 \mathrm{p}$.

Heylmun, E.B., 1999, Rare Earths at Bokan Mountain, Alaska; International California Mining Journal, p. 44-46.

Hodge, E.T., 1944, Southeastern Coastal Alaska Limestone Terrain; Alaska Territorial Department of Mines Miscellaneous Report MR-191-8, 29 p., 2 sheets, scale 1:1,900,800.

MacKevett, E.M., Jr., 1959, Geology of the Ross-Adams Uranium-Thorium Deposit, Alaska; Mining and Engineering (N.Y.) 5909.

Roehm, J.C., 1939, Jack Wilcox Gold Prospect (Nutkwa Property, Nutkwa Bay); Alaska Territorial Department of Mines Prospect Evaluation PE-119-18, 4 p., 2 maps.

Roehm, J.C., 1946, Some High Calcium Limestone Deposits in Southeastern Alaska; Alaska Territorial Department of Mines Pamphlet 6, 20 p.

Rossman, D.L., Henderson, J.R., Jr., and Walton, M.S., Jr., 1956, Reconnaissance Total Intensity Aeromagnetic Map of the Southern Part of Prince of Wales Island, Alaska; U.S. Geological Survey Geophysical Investigations Map GP-135, 1 sheet, scale 1:126,720.

Staatz, M.H., Hall, R.B., Macke, D.L., Armbrustmacher, T.J., and Brownfield, I.K., 1980, Thorium Resources of Selected Regions in the United States; U.S. Geological Survey Circular 824, 32 p.

Thompson, T.B., 1987, Geology and Uranium-Thorium Mineral Deposits of the Bokan Mountain Granite Complex, Southeastern Alaska; Ore Geology Reviews, p. 193-210.

U.S. Bureau of Mines, 1973, Alaska 1:250,000 Scale Quadrangle Map Overlays Showing Mineral Deposit Locations, Principal Minerals, and Number and Type of Claims; Bureau of Mines Open-File Report 20-73, 41 p.

Wallace Miner, 1970, Dawn Uses Option for Sale of Uranium Oxide; Wallace Miner.

Williams, J.A., 1955, Carol Anne Property (Kendrick Bay); Alaska Territorial Department of Mines Prospect Evaluation PE-121-7, 5 p. 
Williams, J.A., 1955, I \& L Property (Kendrick Bay); Alaska Territorial Department of Mines Prospect Evaluation PE-121-5, 8 p.

Williams, J.A., 1955, Lazo Property (Moira Sound); Alaska Territorial Department of Mines Prospect Evaluation PE-121-6, 3 p.

\section{Eagle}

Bottge, R.G., 1975, Comparative Asbestos Mining and Processing Costs--Alaska Versus Yukon Territory; Bureau of Mines Information Circular 8672, $33 \mathrm{p}$.

Cobb, E.H., 1972, Metallic Mineral Resources Map of the Eagle Quadrangle, Alaska; U.S. Geological Survey Miscellaneous Field Studies Map MF-393, 1 sheet, scale 1:250,000.

Foster, H.L., 1969, Asbestos Occurrence in the Eagle C-4 Quadrangle, Alaska; U.S. Geological Survey Circular 611, 7 p.

Mullins, W.J., McOuat, J.F., and Rogers, R.K., 1984, The Alaska Asbestos Project - Project Review; Proceedings of the Industrial Minerals International Congress, p. WJM 1-20.

Saunders, R.H., 1956, Flume Creek, Lode Gold Prospect (Alaska Nickel Co.); Alaska Territorial Department of Mines Prospect Evaluation PE-60-4, 10 p.

\section{Fairbanks}

Alaska Department of Revenue, 1982, Mine License Application.

Cobb, E.H., 1972, Metallic Mineral Resources Map of the Fairbanks Quadrangle, Alaska; U.S. Geological Survey Miscellaneous Field Studies Map MF-410, 1 sheet, scale 1:250,000.

U.S. Bureau of Mines, 1985, Unpublished data, 1970-1985.

U.S. Department of Labor, Mine Safety and Health Administration, 1985, Mine Safety and Health Examinations, 1975-1985.

\section{Goodnews Bay}

Cobb, E.H., and Condon, W.H., 1972, Metallic Mineral Resources Map of the Goodnews Quadrangle, Alaska; U.S. Geological Survey Miscellaneous Field Studies Map MF-447, 1 sheet, scale $1: 250,000$.

\section{Gulkana}

Mulligan, J.J., 1974, Mineral Resources of the Trans-Alaska Pipeline Corridor; Bureau of Mines Information Circular 8626, 24 p., 9 sheets, scale 1:190,080.

Richter, D. H., and Matson, N.A., Jr., 1972, Metallic Mineral Resources Map of the Gulkana Quadrangle, Alaska; U.S. Geological Survey Miscellaneous Field Studies Map MF-419, 1 sheet, scale $1: 250,000$. 
U.S. Department of Labor, Mine Safety and Health Administration, 1985, Mine Safety and Health Examinations, 1975-1985.

\section{Hagemeister Island}

Brooks, A.H., and others, 1915, Mineral Resources of Alaska: Report on Progress of Investigations in 1914; U.S. Geological Survey Bulletin 622, 391 p.

Bundtzen, T.K., Eakins, G.R., and Conwell, C.N., 1982, Review of Alaska's Mineral Resources; Alaska Division of Geological \& Geophysical Surveys and Alaska Department of Commerce and Economic Development.

Cobb, E.H., 1972, Metallic Mineral Resources Map of the Hagemeister Island Quadrangle, Alaska; U.S. Geological Survey Miscellaneous Field Studies Map MF-362, 1 sheet, scale 1:250,000.

Fechner, S.A., 1988, Bureau of Mines Mineral Investigation of the Goodnews Bay Mining District, Alaska; Bureau of Mines Open-File Report 1-88, 230 p.

Griscom, A., 1978, Aeromagnetic Map and Interpretation of the Goodnews and Hagemeister Island Quadrangles Region, Southwestern Alaska; U.S. Geological Survey Open-File Report 78-9-C, 22 p., 2 sheets, scale 1:250,000.

Hoare, J.M., and Coonrad, W.L., 1961, Geologic Map of the Hagemeister Island Quadrangle, Alaska; U.S. Geological Survey Miscellaneous Geologic Investigations Series Map I-321, 1 sheet, scale $1: 250,000$.

Southworth, D.D., and Foley, J.Y., 1986, Lode Platinum-Group Metals Potential of the Goodnews Bay Ultramafic Complex, Alaska; Bureau of Mines Open-File Report 51-86, 82 p., 2 sheets, 1:63,360.

\section{Harrison Bay}

Rawlinson, S.E., 1990, Surficial Geology and Morphology of the Alaskan Central Arctic Coastal Plain; Alaska Division of Geological \& Geophysical Surveys Report Of Investigations 93-1, 172 p., 6 sheets, scale 1:63,360.

\section{Healy}

Berg, H.C., 1972, Geologic Map of Annette Island, Alaska; U.S. Geological Survey Miscellaneous Geologic Investigations Series Map I-684, 8 p., 1 sheet, scale 1:63,360.

Bundtzen, T.K., Eakins, G.R., and Conwell, C.N., 1982, Review of Alaska's Mineral Resources; Alaska Division of Geological \& Geophysical Surveys and Alaska Department of Commerce and Economic Development.

Bundtzen, T.K., and Smith, T.E., 1982, Alaska Industrial Minerals; Alaska Geographic, p. 64-73.

Clark, A.L., and Cobb, E.H., 1972, Metallic Mineral Resources Map of the Healy Quadrangle, Alaska; U.S. Geological Survey Miscellaneous Field Studies Map MF-394, 1 sheet, scale 1:250,000.

Jasper, M.W., and Saunders, R.H., 1955, Reconnaissance of Upper Butte Creek (Susitna River); Alaska Territorial Department of Mines Mineral Investigations MI-67-2, 5 p. 
Moxham, R.M., Eckhart, R.A., and Cobb, E.H., 1960, Geology and Cement Raw Materials of the Windy Creek Area, Alaska; U.S. Geological Survey Bulletin 1039-D, 100 p., 1 sheet, scale 1:48,000.

Rutledge, F.A., Thorne, R.L., Kerns, W.H., and Mulligan, J.J., 1953, Nonmetallic Deposits Accessible to the Alaska Railroad as Possible Sources of Raw Materials for the Construction Industry; Bureau of Mines Report of Investigations 4932, 129 p.

U.S. Bureau of Mines, 1967, Potential Sources of Aluminum; Bureau of Mines Information Circular 8335, 148 p.

U.S. Geological Survey, 1963, Contributions to Economic Geology of Alaska; U.S. Geological Survey Bulletin 1155, 93 p.

Warfield, R.S., 1962, Some Nonmetallic Mineral Resources for Alaska's Construction Industry; Bureau of Mines Report of Investigations 6002, 25 p.

\section{Howard Pass}

Barker, J.C., Still, J.C., Mowatt, T.C., and Mulligan, J.J., 1981, Critical and Strategic Minerals in Alaska: Cobalt, the Platinum-Group Metals, and Chromite; Bureau of Mines Information Circular 8869, 8 p., 1 sheet, scale 1:250,000.

Bates, R.L., 1969, Geology of the Industrial Minerals; Dover, Publications Inc., New York, 459 p.

Churkin, M. Jr., Mayfield, C.F., Theobald, P.K., Barton, H., Nokleberg, W.J., Windler, G.R., and Huie, C., 1978, Geological and Geochemical Appraisal of Metallic Mineral Resources, Southern National Petroleum Reserve in Alaska; U.S. Geological Survey Open-File Report 78-70A, 82 p.

Cobb, E.H., Mayfield, C.F., Brosge, W.P., 1981, Summaries of Data on and Lists of References to Metallic and Selected Non-Metallic Mineral Occurrences in Eleven Quadrangles in Northern Alaska-Summaries of Data to January 1, 1981; U.S. Geological Survey Open-File Report 81-767, 40 p.

Dover, J.H., 1997, Alaska Resource Date File-Howard Pass Quadrangle; U.S. Geological Survey Open-File Report 97-296, 47 p.

Gray, J.E., Sanzolone, R.F., 1996, Environmental Studies of Mineral Deposits in Alaska; U.S. Geological Survey Bulletin 2156, 39 p.

Grybeck, D.J., 1977, Map Showing Known Mineral Deposits of the Brooks Range, Alaska; U.S. Geological Survey Open-File Report 77-166-C, 45 p., 1 sheet, scale 1:1,000,000.

Jansons, U., 1982, Zinc-lead Occurrences in and Near the National Petroleum Reserve in Alaska; U.S. Bureau of Mines Open-File Report MLA 121-82, 55 p.

Jansons, U., and Baggs, D.W., 1980, Mineral Investigations of the Misheguk Mountains and Howard Pass Quadrangles, National Petroleum Reserve-Alaska; U.S. Bureau of Mines Open-File Report 38-80, $76 \mathrm{p}$.

Jansons, U., and Parke, M.A., 1980, 1978 Mineral Investigations of Misheguk Mountain and Howard Pass Quadrangles, Alaska; Bureau of Mines Open-File Report 26-81, 193 p.

Kelley, J.S., Tailleur, I.L., Morin, R.L., Reed, K.M., Harris, A.G., Schmidt, J.M., Brown, F.M., and Kurtak, J.M., 1993, Barite Deposits in the Howard Pass Quadrangle and Possible Relations to Barite Elsewhere in the Northwestern Brooks Range, Alaska; U.S. Geological Survey Open-File Report 93-215, 13 p., 9 sheets, scale 1:63,360. 
Kelley, K.D., Borden, J.C., Bailey, E.A., Fey, D.L., Motooka, J.M., and Roushey, B.H., 1991, Geochemically Anomalous Areas in the West-Central Part of the Howard Pass Quadrangle, National Petroleum Reserve, Alaska: Evidence for Sediment-Hosted Zn-Pb-Ag-Ba Mineralization; U.S. Geological Survey Bulletin 2041, p. 60-69

Kelley, K.D., Leach, D.L., and Johnson, C.A., 1998, Sulfur-, Oxygen-, and Carbon-Isotype Studies of Ag$\mathrm{Pb}-\mathrm{Zn}$ Vein-Breccia Occurrences, Sulfide-Bearing Concretions, and Barite Deposits in the NorthCentral Brooks Range, with Comparisons to Shale-Hosted Stratiform Massive Sulfide Deposits; U.S. Geological Survey Professional Paper 1615, 12 p.

Kurtak, J.M., Hicks, R.W., Werdon, M.B., Meyer, M.P., and Mull, C.G., 1995, Mineral Investigations in the Colville Mining District and Southern National Petroleum Reserve in Alaska; Bureau of Mines Open-File Report, 217 p., 1 sheet, scale 1:250,000.

Mayfield, C.F., Curtis, S.M., Ellersieck, I. F., and Tailleur, I. L., 1979, Reconnaissance Geology of the Ginny Creek Zinc-Lead-Silver and Nimiuktuk Barite Deposits, Northwestern Brooks Range, Alaska; U.S. Geological Survey Open-File Report 79-1092, 21 p., 2 sheets, scale 1:63,360.

Mayfield, C.G., Tailleur, I.L., Mull, C.G., and Sable, E.G., 1978, Bedrock Geologic Map of the South Half of the National Petroleum Reserve in Alaska; U.S. Geological Survey Open-File Report 78-70-B.

Meyer, M.P., and Kurtak, J.M., 1992, Results of the 1991 U.S. Bureau of Mines Colville Mining District Study; U.S. Bureau of Mines Open-File Report 75-92, 101 p.

Morin, R.L., 1997, Gravity Models of Abby Creek and Bion Barite Deposits, Howard Pass Quadrangle, Northwestern Brooks Range, Alaska; U.S. Geological Survey Open-File Report 97-704, 15 p.

Nelson, S.W., Nokleberg, W.J., Miller-Hoare, M., and Mullen, M.W., 1979, Siniktanneyak Mountain Ophiolite, in Johnston, K.M., and Williams, J.R., The United States Geological Survey in Alaska: Accomplishments During 1978; U.S. Geological Survey Circular 804-B, p. B14-B16.

Nokleberg, W.J., and Winkler, G.R., 1978, Geologic Setting of the Lead and Zinc Deposits, Drenchwater Creek Area, Howard Pass Quadrangle, Alaska; U.S. Geological Survey Open-File Report 78-70C, 16 p., 1 sheet, scale 1:19,800.

Nokleberg, W.J., and Winkler, G.R., 1978, Stratiform Zinc-Lead Mineralization, Drenchwater Creek Area, Howard Pass Quadrangle, Western Brooks Range, Alaska; U.S. Geological Survey Circular 772B, p. B15-B17.

Oyler, H., 1993, Baroid Corp. Houston, Texas; Personal Communication.

Patton, W.W., Jr., and Matzko, J.J., 1959, Phosphate Deposits in Northern Alaska; U.S. Geological Survey Professional Paper 302-A, 17 p.

Schmidt, Jeanine M., 1997, Shale-Hosted Zn-Pb-Ag and Barite Deposits of Alaska; Economic Geology Monograph 9, $31 \mathrm{p}$.

Tailleur, I.L., Kent, B.H., and Reiser, H.N., 1966, Outcrop/ Geologic Maps of the Nuka-Etivluk Region, Northern Alaska; U.S. Geological Survey Open-File Report 66-128 (226).

Tailleur, I.L., Pessel, G.H., Brosge', W.P., and Mayfield, C.F., 1976, Informal Cooperation Between U.S. Geological Survey and State of Alaska, Division of Geological and Geophysical Surveys, in the Brooks Range, in Cobb, E.H., ed., The United States Geological Survey in Alaska: Accomplishments During 1975; U.S. Geological Survey Circular 733, p. 29 
Taylor, C.D., Meier, A.L., and d'Angelo, W.M., 1998, A Reconnaissance Study of the Chemistry of Natural Waters Draining Chromite-Bearing Ultramafic Complexes in Alaska U.S. Geological Survey Professional Paper 1595, p. 9-16.

U.S. Bureau of Mines, 1995, Spatial Data Extracted from the Minerals Availability System/ Mineral Industry Location System (MAS/MILS); U.S. Bureau of Mines Special Publication 12-95, CDROM.

U.S. Geological Survey, 1988, Geology and Exploration of the National Petroleum Reserve in Alaska, 1974 to 1982; U.S. Geological Survey Professional Paper 1399, 940 p.

U.S. Geological Survey, 1992, U.S. Geological Survey Emeritus; Written Communication.

\section{Hughes}

Carnes, R.D., 1976, Active Alaskan Placer Operations, 1975; Bureau of Mines Open-File Report 98-76.

Cobb, E.H., 1968, Metallic Mineral Resources Map of the Hughes Quadrangle, Alaska; U.S. Geological Survey Open-File Report 68-44, 4 p., 1 sheet, scale 1:250,000.

Cobb, E.H., 1972, Metallic Mineral Resources Map of the Eagle Quadrangle, Alaska; U.S. Geological Survey Miscellaneous Field Studies Map MF-393, 1 sheet, scale 1:250,000.

Grybeck, D.J., 1977, Map Showing Known Mineral Deposits of the Brooks Range, Alaska; U.S. Geological Survey Open-File Report 77-166-C, 45 p., 1 sheet, scale 1:1,000,000.

Nome Nugget, 1976, Alaska Gold Company: Almost 8,000 Ounces Mined; Nome Nugget Vol. 76, No. 10, $4 \mathrm{p}$.

Patton, W.W., Jr., and Miller, T.P., 1966, Regional Geologic Map of the Hughes Quadrangle, Alaska; U.S. Geological Survey Miscellaneous Geologic Investigations Series Map I-459, 1 sheet, scale $1: 250,000$.

\section{Icy Bay}

Cobb, E.H., 1972, Metallic Mineral Resources Map of the Icy Bay Quadrangle, Alaska; U.S. Geological Survey Miscellaneous Field Studies Map MF-411, 1 sheet, scale 1:250,000.

\section{Iditarod}

Brooks, A.H., and others, 1923, Mineral Resources of Alaska: Report on Progress of Investigations in 1921; U.S. Geological Survey Bulletin 739, 182 p.

Bundtzen, T.K., Eakins, G.R., and Conwell, C.N., 1982, Review of Alaska's Mineral Resources; Alaska Division of Geological \& Geophysical Surveys and Alaska Department of Commerce and Economic Development.

Cobb, E.H., 1972, Metallic Mineral Resources Map of the Iditarod Quadrangle, Alaska; U.S. Geological Survey Miscellaneous Field Studies Map MF-363, 1 sheet, scale 1:250,000.

Cobb, E.H., 1972, Metallic Mineral Resources Map of the Ophir Quadrangle, Alaska; U.S. Geological Survey Miscellaneous Field Studies Map MF-367, 1 sheet, scale 1:250,000. 
Cobb, E.H., 1973, Placer Deposits of Alaska; U.S. Geological Survey Bulletin 1374, 213 p., 1 sheet.

Maloney, R.P., 1962, Investigation of Mercury-Antimony Deposits Near Flat, Yukon River Region, Alaska; Bureau of Mines Report of Investigations 5991, 44 p.

\section{Iliamna}

Berg, H.C., and Cobb, E.H., 1967, Metalliferous Lode Deposits of Alaska; U.S. Geological Survey Bulletin $1246,254 \mathrm{p}$.

Detterman, R.L., and Reed, B.L., 1964, Preliminary Map of the Geology of the Iliamna Quadrangle, Alaska; U.S. Geological Survey Miscellaneous Geologic Investigations Series Map I-407, 1 sheet, scale $1: 250,000$.

Detterman, R.L., and Reed, B.L., 1972, Metallic Mineral Resources Map of the Iliamna Quadrangle, Alaska; U.S. Geological Survey Miscellaneous Field Studies Map MF-364, 1 sheet, scale $1: 250,000$.

MacKevett, E.M., Jr., and Holloway, C.D., 1977, Map Showing Metalliferous Mineral Deposits in the Western Part of Southern Alaska; U.S. Geological Survey Open-File Report 77-169-F, 39 p., 1 sheet, scale 1:1,000,000.

MacKevett, E.M., Jr., and Holloway, C.D., 1977, Map Summarizing Metalliferous and Selected Nonmetalliferous Mineral Deposits in the Eastern Part of Southern Alaska; U.S. Geological Survey Open-File Report 77-169A, 99 p., 1 sheet, scale 1:1,000,000.

Madonna, James A., 1982, Clinoptilolite and Mordenite Deposits of Possible Economic Value at Iliamna Lake, Alaska; Alaska Division of Geological \& Geophysical Surveys Geologic Report 73, p. 1315.

\section{Juneau}

Berg, H.C., Decker, J.E., and Abramson, B.S., 1981, Metallic Mineral Deposits of Southeastern Alaska; U.S. Geological Survey Open-File Report 81-122, 145 p., 1 sheet, scale 1:1,000,000.

Cobb, E.H., 1972, Metallic Mineral Resources Map of the Juneau Quadrangle, Alaska; U.S. Geological Survey Miscellaneous Field Studies Map MF-435, 1 sheet, scale 1:250,000.

Eakins, G.R., 1969, Uranium in Alaska; Alaska Division of Geological \& Geophysical Surveys Geologic Report 38, 49 p., 1 sheet, scale 1:3,800,000.

Lathram, E.H., Loney, R.A., Berg, H.C., and Pomeroy, J.S., 1960, Progress Map of the Geology of Admiralty Island Alaska; U.S. Geological Survey Miscellaneous Geologic Investigations Series Map I-323, 1 sheet, scale 1:250,000.

Lathram, E.H., Loney, R.A., Condon, W.H., and Berg, H.C., 1959, Progress Map of the Geology of the Juneau Quadrangle, Alaska; U.S. Geological Survey Miscellaneous Geologic Investigations Series Map I-303, 1 sheet, scale 1:250,000.

U.S. Bureau of Mines, 1985, Unpublished data, 1970-1985. 
U.S. Department of Labor, Mine Safety and Health Administration, 1985, Mine Safety and Health Examinations, 1975-1985.

\section{Kantishna River}

Heiner, L.E., and Porter, E., 1972, A Computer Processable Storage and Retrieval Program for Alaska Mineral Information--Alaskan Mineral Properties; Mineral Industry Research Laboratory, University of Alaska, Report 24, 814 p.

\section{Karluk}

Becker, G.F., 1898, Reconnaissance of Some Gold Fields of Southern Alaska with Some Notes on General Geology: in Wolcott, Charles D., dir.; U.S. Geological Survey 18th Annual Report, p. 7-86.

Brooks, A.H., 1921, The Future of Alaska Mining, in Martin G.C. and Others, Mineral Resources of Alaska, 1917; U.S. Geological Survey Bulletin 714, p. 5-57.

Capps, S.R., 1937, Kodiak and Adjacent Islands, Alaska, in Smith, P.S. and Others, Mineral Resources of Alaska, 1934; U.S. Geological Survey Bulletin 880, p. 111-184, 1 sheet, scale 1:250,000.

Cobb, E.H., 1972, Metallic Mineral Resources Map of the Karluk Quadrangle, Alaska; U.S. Geological Survey Miscellaneous Field Studies Map MF-459, 1 sheet, scale 1:250,000.

Cobb, E.H., 1973, Placer Deposits of Alaska, U.S. Geological Survey Bulletin 1374, 213 p., 1 sheet.

Cobb, E.H., 1979, Summary of References to Mineral Occurrences in the Afognak, Karluk, Kodiak, and Trinity Islands Quadrangles, Alaska; U.S. Geological Survey Open-File Report 79-860, 49 p.

Dahlin, D.C., Kinney, J.J., and Brown, L.L., 1985, Chromite Deposits Along the Border Ranges Fault, Southern Alaska. (In Two Parts.) 2. Mineralogy and Results of Beneficiatio; Bureau of Mines Information Circular 8991, $37 \mathrm{p}$.

Foley, J.Y., and Barker, J.C., 1985, Chromite Deposits Along the Border Ranges Fault, Southern Alaska. (In Two Parts.) 1. Field Investigations and Descriptions of Chromite Deposits; Bureau of Mines Information Circular 8990, 58 p.

Foley, J.Y., Burns, L.E., Schneider, C.L., and Forbes, R.B., 1989, Preliminary Report of Platinum Group Element Occurrences in Alaska; Alaska Department of Geological and Geophysical Surveys Public Data File 89-20, 33 p., scale 1:2,500,000.

MacKevett, E.M., Jr., and Holloway, C.D., 1977, Map Showing Metalliferous Mineral Deposits in the Western Part of Southern Alaska; U.S. Geological Survey Open-File Report 77-169-F, 39 p., 1 sheet, scale 1:1,000,000.

Maddren, A.G., 1919, The Beach Placers of the West Coast of Kodiak Island, Alaska, in Martin, G.C., and Others, Mineral Resources of Alaska, 1917; U.S. Geological Survey Bulletin 692, p. 299-319.

Martin, G.C., 1913, Mineral Deposits of Kodiak and Neighboring Islands, in Brooks, A.H., and Others, Mineral Resources of Alaska, 1912; U.S. Geological Survey Bulletin 542, p. 125-136.

McGee, D.L., 1972, Kodiak Island and Vicinity, Alaska, Geology and Mineral Resources; Alaska Division of Geological and Geophysical Surveys Open-File Report 31, 7 p., 1 sheet, scale 1:250,000. 
Mertie, J.B., 1969, Economic Geology of the Platinum Minerals; U.S. Geological Survey Professional Paper 630, $120 \mathrm{p}$.

Payne, T.G., Dana, S., Fischer, W., Gryc, G., Lathram, E., Morris, R., Tappan, H., and Yuster, S., 1952, Geology of the Arctic Slope of Alaska; U.S. Geological Survey Oil and Gas Investigations Map 126, 1 sheet, scale 1:1,000,000.

Pilcher, S.H., 1999, Alaska Resource Data File-Karluk Quadrangle; U.S. Geological Survey Open-File Report 99-42, $71 \mathrm{p}$.

Smith, P.S., 1941, The Mineral Industry in 1939, in Smith, P.S., and Others, Mineral Resources of Alaska, 1940; U.S. Geological Survey Bulletin 926, p.1-106.

Smith, P.S., 1933, The Mineral Industry of Alaska in 1930, in Smith, P.S., and Others, Mineral Resources of Alaska, 1930; U.S. Geological Survey Bulletin 836, p. 1-83.

Smith, P.S., 1942, The Mineral Industry of Alaska in 1940, in Smith, P.S., and Others, Mineral Resources of Alaska,

\section{Kenai}

Alaska Department of Revenue, 1982, Mine License Application.

Cobb, E.H., 1972, Metallic Mineral Resources Map of the Kenai Quadrangle, Alaska; U.S. Geological Survey Miscellaneous Field Studies Map MF-377, 1 sheet, scale 1:250,000.

Grantz, A., 1956, Magnetite Deposits at Tuxedni Bay, Alaska; U.S. Geological Survey Bulletin 1024-D, 11 p.

Mulligan, J.J., 1974, Mineral Resources of the Trans-Alaska Pipeline Corridor; Bureau of Mines Information Circular 8626, 24 p., 9 sheets, scale 1:190,080.

Plafker, G., and MacKevett, E.M., Jr, 1956, Occurrence of Diatomaceous Earth Near Kenai, Alaska; U.S. Geological Survey Bulletin 1039-B, 6 p.

U.S. Department of Labor, Mine Safety and Health Administration, 1985, Mine Safety and Health Examinations, 1975-1985.

\section{Ketchikan}

Alaska Department of Revenue, 1982, Mine License Application.

U.S. Bureau of Mines, 1985, Unpublished data, 1970-1985.

U.S. Department of Labor, Mine Safety and Health Administration, 1985, Mine Safety and Health Examinations, 1975-1985.

\section{Killik River}

Barker, J.C., 1978, Mineral Investigations of Certain Lands in the Eastern Brooks Range, 1978: A Summary Report; Bureau of Mines Open-File Report 63-78, 25 p. 
Brosge', W.R., and Reiser, H.N., 1968, Geochemical Maps of Granitic Rocks, Coleen and Table Mountain Quadrangles, Alaska; U.S. Geological Survey Open-File Report 323, Scale 1:250,000.

Brosge', W.R., and Reiser, H.N., 1976, Preliminary Geologic and Mineral Resource Maps (excluding petroleum), Arctic National Wildlife Range, Alaska; U.S. Geological Survey Open-File Report 76-539, 4 p., scale 1:500,000.

Grybeck, D.J., 1977, Map Showing Known Mineral Deposits of the Brooks Range, Alaska; U.S. Geological Survey Open-File Report 77-166-C, 45 p., 1 sheet, scale 1:1,000,000.

Kelley, K.D., 1997, Alaska Resource Data File-Killik River Quadrangle; U.S. Geological Survey Open-File Report 97-266, 20 p.

Kurtak, J.M., Hicks, R.W., Werdon, M.B., Meyer, M.P., and Mull, C.G., 1995, Mineral Investigations in the Colville Mining District and Southern National Petroleum Reserve in Alaska; Bureau of Mines Open-File Report 8-95, 217 p., 1 sheet, scale 1:250,000.

Meyer, M.P., and Kurtak, J.M., 1992, Results of the 1991 U.S. Bureau of Mines Colville Mining District Study; U.S. Bureau of Mines Open-File Report 75-92, 101 p.

O'Conner, W.K., 1992, BuMines Research Center, Salt Lake City, Utah; Written Communication, November 1992.

Summers, C.A., 1992, Mineralogy of the Ivotuk Hills Phosphate Occurrence, Colville Mining District, Alaska; U.S. Bureau of Mines, Unpublished Report, 6 p.

\section{Kodiak}

Cobb, E.H., 1972, Metallic Mineral Resources Map of the Iditarod Quadrangle, Alaska; U.S. Geological Survey Miscellaneous Field Studies Map MF-363, 1 sheet, scale 1:250,000.

Dahlin, D.C., Kinney, J.J., and Brown, L.L., 1985, Chromite Deposits Along the Border Ranges Fault, Southern Alaska. (In Two Parts.) 2. Mineralogy and Results of Beneficiatio; Bureau of Mines Information Circular 8991, $37 \mathrm{p}$.

Foley, J.Y., and Barker, J.C., 1985, Chromite Deposits Along the Border Ranges Fault, Southern Alaska. (In Two Parts.) 1. Field Investigations and Descriptions of Chromite Deposits; Bureau of Mines Information Circular 8990, 58 p.

Pilcher, S.H., 1999, Alaska Resource Data File-Kodiak Quadrangle; U.S. Geological Survey Open-File Report 99-43, 67 p.

U.S. Department of Labor, Mine Safety and Health Administration, 1985, Mine Safety and Health Examinations, 1975-1985.

\section{Kotzebue}

Cobb, E.H., 1972, Metallic Mineral Resources Map of the Livengood Quadrangle, Alaska; U.S. Geological Survey Miscellaneous Field Studies Map MF-413, 1 sheet, scale 1:250,000. 


\section{Lake Clark}

Cobb, E.H., 1972, Metallic Mineral Resources Map of the Karluk Quadrangle, Alaska; U.S. Geological Survey Miscellaneous Field Studies Map MF-459, 1 sheet, scale 1:250,000.

Warfield, R.S., and Rutledge, F.A., 1951, Investigation of Kasna Creek Copper Prospect, Lake Kontrashibuna, Lake Clark Region, Alaska; Bureau of Mines Report of Investigations 4828, 10 p.

\section{Lime Hills}

Bundtzen, T.K., and Gilbert, W.G., 1991, Geology and Geochemistry of the Gargaryah Barite Deposit, Western Alaska Range, Alaska; Alaska Division of Geological \& Geophysical Surveys Professional Report 111, p. 9-20.

Bundtzen, T.K., Laird, G.M., Blodgett, R.B., Clautice, K.H., and Harris, E.E., 1994, Geology of the Gargaryah River Area, Lime Hills C-5 and C-6 Quadrangles, Southwest Alaska; Alaska Division of Geological and Geophysical Surveys Public-Data File 94-40, 17 p., scale 1:63,360.

Schmidt, Jeanine M., 1997, Shale-Hosted Zn-Pb-Ag and Barite Deposits of Alaska; Economic Geology Monograph 9, $31 \mathrm{p}$.

\section{Livengood}

Armbrustmacher, T.J., 1989, Minor Element Content, Including Radioactive Elements and Rare-Earth Elements, in Rocks from the Syenite Complex at Roy Creek, Mount Prindle Area, Alaska; U.S. Geological Survey Open-File Report 89-0146, 11 p.

Bundtzen, T.K., Eakins, G.R., and Conwell, C.N., 1982, Review of Alaska's Mineral Resources; Alaska Division of Geological \& Geophysical Surveys and Alaska Department of Commerce and Economic Development.

Cobb, E.H., 1972, Metallic Mineral Resources Map of the Livengood Quadrangle, Alaska; U.S. Geological Survey Miscellaneous Field Studies Map MF-413, 1 sheet, scale 1:250,000.

Cobb, E.H., 1972, Metallic Mineral Resources Map of the Tanana Quadrangle, Alaska; U.S. Geological Survey Miscellaneous Field Studies Map MF-371, 1 sheet, scale 1:250,000.

Foster, R.L., and Chapman, R.M., 1967, Locations and Descriptions of Lode Prospects in the Livengood Area, East-Central Alaska; U.S. Geological Survey Open-File Report 67-91, 6 p.

Hargreaves, D., 1975, The Livengood Placer Deposit--A Developing Alaskan Gold Mine; Mining Magazine 7505, 4 p.

Mining World, 1951, Alaska--Gold Output at Post-War Peak: Platinum and Tin Placering; Mining World.

Mulligan, J.J., 1974, Mineral Resources of the Trans-Alaska Pipeline Corridor; Bureau of Mines Information Circular 8626, 24 p., 9 sheets, scale 1:190,080.

Saunders, R.H., 1958, Notes on Mineral Resources of the Livengood Creek, Hess Creek, and Their Tributaries; Alaska Territorial Department of Mines Miscellaneous Report MR-49-3, 5 p. 


\section{McCarthy}

Cobb, E.H., 1980, Summaries of Data on and Lists of References to Metallic and Selected Nonmetallic Mineral Deposits in the McCarthy Quadrangle, Alaska; U.S. Geological Survey Open-File Report $80-885,157$ p.

MacKevett, E.M., Jr., 1976, Mineral Deposits and Occurrences in the McCarthy Quadrangle, Alaska; U.S. Geological Survey Miscellaneous Field Studies Map MF-773-B, 1 sheet, scale 1:250,000.

MacKevett, E.M., Jr., and Cobb, E.H., 1972, Metallic Mineral Resources Map of the McCarthy Quadrangle, Alaska; U.S. Geological Survey Miscellaneous Field Studies Map MF-395, 1 sheet, scale 1:250,000.

\section{McGrath}

Bundtzen, T.K., Laird, G.M., and Gilbert, W.G., 1989, Material Studies Along Kuskokwim River, McGrath to Kalskag, Southwest Alaska; Alaska Division of Geological \& Geophysical Surveys Public Data File PDF 89-16, 84 p.

\section{Medfra}

Cobb, E.H., 1972, Metallic Mineral Resources Map of the Ambler River Quadrangle, Alaska; U.S. Geological Survey Miscellaneous Field Studies Map MF-454, 1 sheet, scale 1:250,000.

Cobb, E.H., 1972, Metallic Mineral Resources Map of the Iliamna Quadrangle, Alaska; U.S. Geological Survey Miscellaneous Field Studies Map MF-365, 1 sheet, scale 1:250,000.

Thomas, B., 1948, Nixon Fork Mining District; Alaska Territorial Department of Mines Miscellaneous Report MR-65-2, 43 p.

\section{Melozitna}

Cobb, E.H., 1972, Metallic Mineral Resources Map of the Big Delta Quadrangle, Alaska; U.S. Geological Survey Miscellaneous Field Studies Map MF-388, 1 sheet, scale 1:250,000.

\section{Misheguk Mountain}

Barnes, D.F., Mayfield, C.F., Morin, R.L., and Brynn, S., 1982, Gravity Measurements Useful in the Preliminary Evaluation of the Nimiuktuk Barite Deposit, Alaska; Economic Geology, v. 77, p. 185-198.

Bundtzen, T.K., Swainbank, R.C., Clough, A.H., Henning, M.W., and Charlie, K.M., 1996, Alaska's Mineral Industry 1995; Alaska Division of Geological and Geophysical Surveys, Special Report 50, p. 62 .

Churkin, M. Jr., Mayfield, C.F., Theobald, P.K., Barton, H., Nokleberg, W.J., Windler, G.R., and Huie, C., 1978, Geological and Geochemical Appraisal of Metallic Mineral Resources, Southern National Petroleum Reserve in Alaska; U.S. Geological Survey Open-File Report 78-70A, 82 p. 
Cobb, E.H., Mayfield, C.F., Brosge, W.P., 1981, Summaries of Data on and Lists of References to Metallic and Selected Non-Metallic Mineral Occurrences in Eleven Quadrangles in Northern Alaska-Summaries of Data to January 1, 1981; U.S. Geological Survey Open-File Report 81-767, 40 p.

Degenhart, C.E., Griffis, R.J., McOuat, J.F., and Bigelow, C.G., 1978, Mineral Studies of the Western Brooks Range Performed Under Contract to the U.S. Bureau of Mines, Contract \#J0155089, Vol. 1; Bureau of Mines Open-File Report 103-78, 544 p., 11 sheets, scale 1:63,360.

Dover, J.H., 1997, Alaska Resource Date File-Misheguk Mountain Quadrangle; U.S. Geological Survey Open-File Report 97-297, 18 p.

Foley, J.Y., Barker, J.C., and Brown, L.B., 1985, Critical and Strategic Minerals Investigations in Alaska: Chromium; U.S. Bureau of Mines Open File Report 97-85, 54 p.

Foley, J.Y., Burns, L.E., Schneider, C.L., and Forbes, R.B., 1989, Preliminary Report of Platinum Group Element Occurrences in Alaska; Alaska Department of Geological and Geophysical Surveys Public Data File 89-20, 33 p., scale 1:2,500,000.

Gaccetta, J.D., and Church, S.E., 1989, Lead Isotope Data Base for Sulfide Occurrences from Alaska, December, 1989; U.S. Geological Survey Open-File Report 89-688, 60 p.

Grybeck, D.J., 1977, Map Showing Known Mineral Deposits of the Brooks Range, Alaska; U.S. Geological Survey Open-File Report 77-166-C, 45 p., 1 sheet, scale 1:1,000,000

Kelley, J.S., Tailleur, I.L., Morin, R.L., Reed, K.M., Harris, A.G., Schmidt, J.M., Brown, F.M., and Kurtak, J.M., 1993, Barite Deposits in the Howard Pass Quadrangle and Possible Relations to Barite Elsewhere in the Northwestern Brooks Range, Alaska; U.S. Geological Survey Open-File Report 93-215, 13 p., 9 sheets, scale 1:63,360.

Mayfield, C.F., Curtis, S.M., Ellersieck, I. F., and Tailleur, I. L., 1979, Reconnaissance Geology of the Ginny Creek Zinc-Lead-Silver and Nimiuktuk Barite Deposits, Northwestern Brooks Range, Alaska; U.S. Geological Survey Open-File Report 79-1092, 21 p., 2 sheets, scale 1:63,360.

Schmidt, Jeanine M., 1997, Shale-Hosted Zn-Pb-Ag and Barite Deposits of Alaska; Economic Geology Monograph 9, $31 \mathrm{p}$.

U.S. Bureau of Mines, 1995, Spatial Data Extracted from the Minerals Availability System/ Mineral Industry Location System (MAS/MILS); U.S. Bureau of Mines Special Publication 12-95, CDROM.

\section{Mount Fairweather}

American Exploration \& Mining Co. \& Walper, 1966, Muir Inlet Nunatak Drill Logs; Alaska Territorial Department of Mines Miscellaneous Report MR-111-2, 42 p., 1 map.

Apell, G.A., Erickson, A.E., and Tolonen, A.W., 1943, Muir Inlet or Nunatak Molybdenum Deposits, Glacier Bay, Southeastern Alaska; Bureau of Mines War Minerals Report 300, 4 p.

Berg, H.C., Decker, J.E., and Abramson, B.S., 1981, Metallic Mineral Deposits of Southeastern Alaska; U.S. Geological Survey Open-File Report 81-122, 145 p., 1 sheet, scale 1:1,000,000.

Brew, D.A., Johnson, B.R., Grybeck, D.J., Griscom, A., and Barnes, D.F., 1978, Mineral Resources of the Glacier Bay National Wilderness Study Area, Alaska; U.S. Geological Survey Open-File Report 78-494, 670 p., 6 sheets, scale 1:125,000. 
Cobb, E.H., 1972, Metallic Mineral Resources Map of the Mount Fairweather Quadrangle, Alaska; U.S. Geological Survey Miscellaneous Field Studies Map MF-436, 1 sheet, scale 1:250,000.

Cobb, E.H., 1973, Placer Deposits of Alaska; U.S. Geological Survey Bulletin 1374, 213 p., 1 sheet.

Fisher, R.B., Thorne, R.L., and VanCott, C., 1945, Paligorskite: A Possible Asbestos Substitute; Bureau of Mines Information Circular 7313, 5 p.

MacKevett, E.M., Jr., Brew, D.A., Hawley, C.C., Huff, L.C., and Smith, J.G., 1967, Mineral Resources of Glacier Bay National Monument, Alaska; U.S. Geological Survey Open-File Report 67-151, 176 p., 10 sheets, $1: 125,000$.

MacKevett, E.M., Jr., Brew, D.A., Hawley, C.C., Huff, L.C., and Smith, J.G., 1971, Mineral Resources of Glacier Bay National Monument, Alaska; U.S. Geological Survey Professional Paper 632, 90 p., 8 sheets, scale 1:250,000.

Rossman, D.L., 1957, Ilmenite-Bearing Beach Sands Near Lituya Bay, Alaska; U.S. Geological Survey Open-File Report 57-98, 11 p., 1 sheet, scale 1:125,000.

Shepard, J.G., 1926, Smith Prospect (Willoughby Island); Alaska Territorial Department of Mines Prospect Evaluation PE-111-1, 4 p.

Storm, L.W., 1917, Report on the Dundas Bay Iron Property; Alaska Juneau Gold Mining Co.

Thomas, B.I., and Berryhill, R.V., 1962, Reconnaissance Studies of Alaskan Beach Sands, Eastern Gulf of Alaska; Bureau of Mines Report of Investigations 5986, 40 p.

U.S. Bureau of Mines, 1943, Molybdenum Deposits, Muir Inlet, Alaska; Bureau of Mines War Minerals Report 40, 7 p.

\section{Mount Hayes}

Bundtzen, T.K., Eakins, G.R., and Conwell, C.N., 1982, Review of Alaska's Mineral Resources; Alaska Division of Geological \& Geophysical Surveys and Alaska Department of Commerce and Economic Development.

Cobb, E.H., 1972, Metallic Mineral Resources Map of the Mount Hayes Quadrangle, Alaska; U.S. Geological Survey Miscellaneous Field Studies Map MF-414, 1 sheet, scale 1:250,000.

Mulligan, J.J., 1974, Mineral Resources of the Trans-Alaska Pipeline Corridor; Bureau of Mines Information Circular 8626, 24 p., 9 sheets, scale 1:190,080.

U.S. Department of Labor, Mine Safety and Health Administration, 1985, Mine Safety and Health Examinations, 1975-1985.

\section{Mount Katmai}

Moxham, R.M., 1952, Pumice Deposits in the Alaska Peninsula-Cook Inlet Region; U.S. Geological Survey Open-File Report 52-103, 21 p., 5 sheets, scales 1:253,440, 1:95,040, and 1:950,400. 


\section{Mount McKinley}

Berg, H.C., and Cobb, E.H., 1967, Metalliferous Lode Deposits of Alaska; U.S. Geological Survey Bulletin $1246,254 \mathrm{p}$.

Bundtzen, T.K., Eakins, G.R., and Conwell, C.N., 1982, Review of Alaska's Mineral Resources; Alaska Division of Geological \& Geophysical Surveys and Alaska Department of Commerce and Economic Development.

Cobb, E.H., 1972, Metallic Mineral Resources Map of the Mount McKinley Quadrangle, Alaska; U.S. Geological Survey Miscellaneous Field Studies Map MF-366, 1 sheet, scale 1:250,000.

MacKevett, E.M., Jr., and Holloway, C.D., 1977, Map Summarizing Metalliferous and Selected Nonmetalliferous Mineral Deposits in the Eastern Part of Southern Alaska; U.S. Geological Survey Open-File Report 77-169A, 99 p., 1 sheet, scale 1:1,000,000.

\section{Mount Michelson}

Cobb, E.H., 1972, Metallic Mineral Resources Map of the Mt. Michelson Quadrangle, Alaska; U.S. Geological Survey Miscellaneous Field Studies Map MF-462, 1 sheet, scale 1:250,000.

Detterman, R.L., 1989, Triassic Phosphate Deposits, North-Eastern Alaska, USA; Phosphate Deposits of the World, vol. 2, p. 14-17.

\section{Nabesna}

Foley, J.Y., Barker, J.C., and Brown, L.B., 1985, Critical and Strategic Minerals Investigations in Alaska: Chromium; U.S. Bureau of Mines Open File Report 97-85, 54 p.

Matson, N.A., and Richter, D.H., 1971, Geochemical Data from the Nabesna A-1 Quadrangle, Alaska; U.S. Geological Survey Open-File Report 71-0202, 10 p.

Matson, N.A., and Richter, D.H., 1971, Geochemical Data from the Nabesna C-5 Quadrangle, Alaska; U.S. Geological Survey Open-File Report 71-0204, 10 p.

Richter, D.H., 1970, A Corundum Occurrence in the Eastern Alaska Range, Alaska; U.S. Geological Survey Professional Paper 700-C, p. C98-C102.

Richter, D.H., 1997, Alaska Resource Data File-Nabesna Quadrangle; U.S. Geological Survey Open-File Report 97-749, 93 p.

Richter, D.H., 1967, Geology of the Upper Slana-Mentasta Pass Area, South-Central Alaska; Alaska Division of Geological and Geophysical Surveys Geological Report 30, 1 sheet, scale 1:63,360, 27 p.

Richter, D.H., 1971, Reconnaissance Geologic Map, and Section of the Nabesna A-3 Quadrangle, Alaska; U.S. Geological Survey Miscellaneous Investigations Series Map I-655, scale 1:63,360.

Richter, D.H., and Matson, N.A., 1969, Geochemical Data from the Nabesna A-3 Quadrangle, Alaska; U.S. Geological Survey Open-File Report 69-223, 5 p., 1 sheet, scale 1:63,360.

Richter, D.H., and Matson, N.A., Jr., 1972, Metallic Mineral Resources Map of the Nabesna Quadrangle, Alaska; U.S. Geological Survey Miscellaneous Field Studies Map MF-422, 1 sheet, scale $1: 250,000$. 
Richter, D.H., and Others, 1973, Reconnaissance Geologic Map of the Nabesna A-1 Quadrangle, Alaska; U.S. Geological Survey Miscellaneous Investigations Series Map I-807, scale 1:63,360.

Richter, D.H., and Schmoll, 1973, Geologic Map of the Nabesna C-5 Quadrangle, Alaska; U.S. Geological Survey Geologic Quadrangle Map GQ-1062, scale 1:63,360.

Richter, D.H., Singer, D.A., and Cox, D.P., 1975, Mineral Resources Map of the Nabesna Quadrangle, Alaska; U.S. Geological Survey Miscellaneous Field Studies Map MF-655-K, 1 sheet, scale 1:250,000.

U.S. Bureau of Mines, 1995, Spatial Data Extracted from the Minerals Availability System/ Mineral Industry Location System (MAS/MILS); U.S. Bureau of Mines Special Publication 12-95, CDROM.

U.S. Department of Labor, Mine Safety and Health Administration, 1985, Mine Safety and Health Examinations, 1975-1985.

\section{Naknek}

Cobb, E.H., 1972, Metallic Mineral Resources Map of the Dixon Entrance Quadrangle, Alaska; U.S. Geological Survey Miscellaneous Field Studies Map MF-434, 1 sheet, scale 1:250,000.

\section{Noatak}

Saunders, R.H., 1955, Sours Chromium Prospect (Agashashok River); Alaska Territorial Department of Mines Prospect Evaluation PE-26-1, 4 p.

U.S. Bureau of Mines, 1985, Unpublished data, 1970-1985.

\section{Nome}

Cobb, E.H., 1972, Metallic Mineral Resources Map of the Nome Quadrangle, Alaska; U.S. Geological Survey Miscellaneous Field Studies Map MF-463, 1 sheet, scale 1:250,000.

Hudson, T.L., Miller, M.L., and Peckthorn, W.J., 1977, Map Showing Metalliferous and Selected Nonmetalliferous Mineral Deposits, Seward Peninsula, Alaska; U.S. Geological Survey Open-File Report 77-796-B, 46 p., 1 sheet, scale 1:1,000,000.

Hummel, C.H., 1962, Preliminary Geologic Map of the Nome D-1 Quadrangle, Seward Peninsula, Alaska; U.S. Geological Survey Miscellaneous Field Studies Map MF-248, 1 sheet, scale 1:63,360.

U.S. Department of Labor, Mine Safety and Health Administration, 1985, Mine Safety and Health Examinations, 1975-1985.

U.S. Geological Survey, 1971, Geological Survey Research 1971; U.S. Geological Survey Professional Paper 750-D, 223 p. 


\section{Nulato}

Foley, J.Y., Hinderman, T., Kirby, D.E., and Mardock, C.L., 1983, Chromite Occurrences in the Kaiyuh Hills, West-Central Alaska; Bureau of Mines Open-File Report 178-84, 20 p.

U.S. Department of Labor, Mine Safety and Health Administration, 1985, Mine Safety and Health Examinations, 1975-1985.

\section{Ophir}

Cobb, E.H., 1972, Metallic Mineral Resources Map of the Ophir Quadrangle, Alaska; U.S. Geological Survey Miscellaneous Field Studies Map MF-367, 1 sheet, scale 1:250,000.

Roberts, W.S., 1984, Economic Potential for Chromium, Platinum, and Palladium in the Mount Hurst Ultramafics, West-Central Area, Alaska; Bureau of Mines Open-File Report 22-84, 52 p.

\section{Petersburg}

Berg, H.C., and Cobb, E.H., 1967, Metalliferous Lode Deposits of Alaska; U.S. Geological Survey Bulletin $1246,254 \mathrm{p}$.

Berg, H.C., Decker, J.E., and Abramson, B.S., 1981, Metallic Mineral Deposits of Southeastern Alaska; U.S. Geological Survey Open-File Report 81-122, 145 p., 1 sheet, scale 1:1,000,000.

Bundtzen, T.K., Eakins, G.R., and Conwell, C.N., 1982, Review of Alaska's Mineral Resources; Alaska Division of Geological \& Geophysical Surveys and Alaska Department of Commerce and Economic Development.

Cobb, E.H., 1972, Metallic Mineral Resources Map of the Petersburg Quadrangle, Alaska; U.S. Geological Survey Miscellaneous Field Studies Map MF-415, 1 sheet, scale 1:250,000.

Eakins, G.R., 1975, Uranium Investigations in Southeastern Alaska; Alaska Division of Geological \& Geophysical Surveys Geologic Report 44, 62 p.

Glover, A.E., 1951, Salmon Bay-Red Bay Reconnaissance (Prince of Wales Island); Alaska Territorial Department of Mines Mineral Investigation MI-117-1, 6 p.

Karl, S.M., Berg, H.C., Grybeck, D.J., and Abramson, B.S., 1980, Preliminary Map and Tables Describing Metalliferous and Selected Nonmetalliferous Mineral Deposits in the Petersburg \& E. Port Alexander Quadrangles Alaska; U.S. Geological Survey Open-File Report 80-793, 14 p., 1 sheet, scale 1:250,000.

U.S. Bureau of Mines, 1985, Unpublished data, 1970-1985.

U.S. Department of Labor, Mine Safety and Health Administration, 1985, Mine Safety and Health Examinations, 1975-1985.

Warner, J.D., 1989, Columbium-, Rare-Earth-Element-, and Thorium-Bearing Veins Near Salmon Bay, Southeastern Alaska; U.S. Bureau of Mines Open-File Report 06-89, 25 p.

Wedow, H., Jr., and others, 1953, Preliminary Summary of Reconnaissance for Uranium and Thorium in Alaska, 1952; U.S. Geological Survey Circular 248, 15 p., 1 sheet, scale 1:11,088,000. 


\section{Philip Smith Mountains}

Mulligan, J.J., 1974, Mineral Resources of the Trans-Alaska Pipeline Corridor; Bureau of Mines Information Circular 8626, 24 p., 9 sheets, scale 1:190,080.

\section{Port Alexander}

Bundtzen, T.K., Eakins, G.R., and Conwell, C.N., 1982, Review of Alaska's Mineral Resources; Alaska Division of Geological \& Geophysical Surveys and Alaska Department of Commerce and Economic Development.

Cobb, E.H., 1972, Metallic Mineral Resources Map of the Port Alexander Quadrangle, Alaska; U.S. Geological Survey Miscellaneous Field Studies Map MF-464, 1 sheet, scale 1:250,000.

Roehm, J.C., 1938, Children Group (Hungerford Creek); Alaska Territorial Department of Mines Prospect Evaluation PE-116-1, 2 p.

Twenhofel, W.S., Reed, J.C., and Gates, G.O., 1949, Some Mineral Investigations in Southeastern Alaska; U.S. Geological Survey Bulletin 963-A, 44 p.

U.S. Bureau of Mines, 1973, Alaska 1:250,000 Scale Quadrangle Map Overlays Showing Mineral Deposit Locations, Principal Minerals, and Number and Type of Claims; Bureau of Mines Open-File Report 20-73, 41 p.

U.S. Department of Labor, Mine Safety and Health Administration, 1985, Mine Safety and Health Examinations, 1975-1985.

Williams, J.A., 1951, Juneau, Sitka, and Petersburg Precincts; Alaska Territorial Department of Mines Itinerary Report IR-191-1, 5 p.

\section{Port Moller}

Cobb, E.H., 1972, Metallic Mineral Resources Map of the Port Moller Quadrangle, Alaska; U.S. Geological Survey Miscellaneous Field Studies Map MF-443, 1 sheet, scale 1:250,000.

\section{Prince Rupert}

Barker, J.C., Still, J.C., Mowatt, T.C., and Mulligan, J.J., 1981, Critical and Strategic Minerals in Alaska: Cobalt, the Platinum-Group Metals, and Chromite; Bureau of Mines Information Circular 8869, 8 p., 1 sheet, scale 1:250,000.

Berg, H.C., 1972, Geologic Map of Annette Island, Alaska; U.S. Geological Survey Miscellaneous Geologic Investigations Series Map I-684, 8 p., 1 sheet, scale 1:63,360.

Berg, H.C., 1999, Alaska Resource Data File-Prince Rupert Quadrangle; U.S. Geological Survey Open-File Report 99-306, 16 p.

Berg, H.C., Decker, J.E., and Abramson, B.S., 1981, Metallic Mineral Deposits of Southeastern Alaska; U.S. Geological Survey Open-File Report 81-122, 145 p., 1 sheet, scale 1:1,000,000. 
Berg, H.C., Elliott, R.L., and Koch, R.D., 1978, Map and Tables Describing Areas of Metalliferous Mineral Resource Potential in the Ketchikan and Prince Rupert Quadrangles, Alaska; U.S. Geological Survey Open-File Report 78-73M, scale 1:250,000, 48 p. pamphlet.

Berg, H.C., Elliott, R.L., and Koch, R.D., 1988, Geologic Map of the Ketchikan and Prince Rupert Quadrangles, Southeastern Alaska; U.S. Geological Survey Miscellaneous Investigations Series Map I-1807, scale 1:250,000.

Campbell, L.J., 1995, Alaska's Mineral Industry Today; Alaska Geographic, v.22, no.3, p. 31-65.

Clark, A.L., and Greenwood, W.R., 1972, Geochemistry and Distribution of Platinum-Group Metals in Mafic to Ultramafic Complexes of Southern and Southeastern Alaska, in Geological Survey Research; U.S. Geological Survey Professional Paper 800-C, p. C157-C160.

Cobb, E.H., 1972, Metallic Mineral Resources Map of the Ketchikan Quadrangle, Alaska; U.S. Geological Survey Miscellaneous Field Studies Map MF-420, 1 sheet, scale 1:250,000.

Cobb, E.H., 1972, Metallic Mineral Resources Map of the Prince Rupert Quadrangle, Alaska; U.S. Geological Survey Miscellaneous Field Studies Map MF-437, 1 sheet, scale 1:250,000.

Cobb, E.H., and Elliott, R.L., 1980, Summary of Data on and Lists of References to Metallic and Selected Nonmetallic Mineral Deposits in the Ketchikan and Prince Rupert Quadrangles, Alaska; U.S. Geological Survey Open-File Report 80-1053, 156 p.

Elliott, R.L., Berg, H.C., and Karl, S.M., 1978, Map and Table Describing Metalliferous and Selected Nonmetalliferous Mineral Deposits, Ketchikan and Prince Rupert Quadrangles, Alaska; U.S. Geological Survey Open-File Report 78-73-B, 17 p., 1 sheet, scale 1:250,000.

Glover, A.E., 1954, Kelp and Duke Islands Magnetics; Alaska Territorial Department of Mines Mineral Investigation MI-122-2, $1 \mathrm{p}$.

Irvine, T.N., 1974, Petrology of the Duke Island Ultramafic Complex, Southeastern Alaska; Geological Society of America Memoir 138, 240 p.

MacKevett, E.M., 1963, Geology and Ore Deposits of the Bokan Mountain Uranium-Thorium Area, Southeastern Alaska; U.S. Geological Survey Bulletin 1154, 125 p.

Roehm, J.C., 1945, Preliminary Report of Investigations and Itinerary of J.C. Roehm in the Ketchikan and Hyder Mining Precincts, July 14-August 18, 1945; Alaska Territorial Department of Mines Itinerary Report 195-36, 14 p.

Sainsbury, C.L., 1957, Some Pegmatite Deposits in Southeastern Alaska; U.S. Geological Survey Bulletin 1024-G, p. 141-161.

Taylor, H.P., and Noble, J.A., 1960, Origin of the Ultramafic Complexes in Southeastern Alaska; International Geological Congress, 21st, Copenhagen, Report, p. 175-187.

U.S. Bureau of Mines, 1974, Claim Map, Prince Rupert; U.S. Bureau of Mines Map, no. 122, Scale $1: 250,000$.

\section{Ruby}

Cobb, E.H., 1972, Metallic Mineral Resources Map of the Ruby Quadrangle, Alaska; U.S. Geological Survey Miscellaneous Field Studies Map MF-405, 1 sheet, scale 1:250,000. 


\section{Russian Mission}

Bundtzen, T.K., Laird, G.M., and Gilbert, W.G., 1989, Material Studies Along Kuskokwim River, McGrath to Kalskag, Southwest Alaska; Alaska Division of Geological \& Geophysical Surveys Public Data File PDF 89-16, 84 p.

Hoare, J.M., and Cobb, E.H., 1972, Metallic Mineral Resources Map of the Russian Mission Quadrangle, Alaska; U.S. Geological Survey Miscellaneous Field Studies Map MF-444, 1 sheet, scale $1: 250,000$.

Hoare, J.M., and Coonrad, W.L., 1959, Geology of the Russian Mission Quadrangle, Alaska; U.S. Geological Survey Miscellaneous Geologic Investigations Series Map I-292, 1 sheet, scale $1: 250,000$.

\section{Sagavanirktok}

Mulligan, J.J., 1974, Mineral Resources of the Trans-Alaska Pipeline Corridor; Bureau of Mines Information Circular 8626, 24 p., 9 sheets, scale 1:190,080.

\section{Seldovia}

Alaska Department of Revenue, 1982, Mine License Application.

Bain, H.F., 1946, Alaska's Minerals as a Basis for Industry; Bureau of Mines Information Circular 7379, 89 p.

Berg, H.C., and Cobb, E.H., 1967, Metalliferous Lode Deposits of Alaska; U.S. Geological Survey Bulletin $1246,254 \mathrm{p}$.

Bird, M.L., 1977, Electron-Microprobe Analysis of Chromite and Olivine From Alpine Ultramafic Complexes; U.S. Geological Survey Open-File Report 77-236, 66 p.

Bird, M.L., 1978, Electron-Microprobe Study of Chromitites Associated with Alpine Ultramafic Complexes and Some Genetic Implications; U.S. Geological Survey Open File Report 78-119, 39 p.

Brooks, A.H., 1918, The Alaska Mining Industry in 1916, in Brooks, A.H., and others, Mineral Resources of Alaska, 1916; U.S. Geological Survey Bulletin 662, p. 11-62.

Brooks, A.H., 1921, The Future of Alaska Mining, in Martin G.C. and Others, Mineral Resources of Alaska, 1917; U.S. Geological Survey Bulletin 714, p. 5-57.

Burns, L.E., 1985, The Border Range Ultramafic and Mafic Complex, Southcentral Alaska: Cumulative Fractionates of Island-Arc Volcanics; Canadian Journal of Earth Science, v. 22, p. 1020-1038.

Campbell, L.J., 1995, Alaska's Mineral Industry Today; Alaska Geographic, v.22, no.3, p. 31-65.

Cobb, E.H., 1972, Metallic Mineral Resources Map of the Seldovia Quadrangle, Alaska; U.S. Geological Survey Miscellaneous Field Studies Map MF-397, 1 sheet, scale 1:250,000.

Cobb, E.H., 1979, Summary of References to Mineral Occurrences (other than minerals fuels and construction materials) in the Seldovia Quadrangle, Alaska; U.S. Geological Survey Open-File Report 80-87, 47 p. 
Dahlin, D.C., Kinney, J.J., and Brown, L.L., 1982, Alluvial Chromite Deposits, Red Mountain District, Kenai Peninsula, Alaska; Bureau of Mines.

Dahlin, D.C., Kinney, J.J., and Brown, L.L., 1985, Chromite Deposits Along the Border Ranges Fault, Southern Alaska. (In Two Parts.) 2. Mineralogy and Results of Beneficiatio; Bureau of Mines Information Circular 8991, 37 p.

Foley, J.Y., 1992, Ophiolite and Other Ultramafic Metallogenic Provinces in Alaska (west of the 141th meridian); U.S. Geological Survey Open-File Report 92-20B, 65 p.

Foley, J.Y., and Barker, J.C., 1985, Chromite Deposits Along the Border Ranges Fault, Southern Alaska. (In Two Parts.) 1. Field Investigations and Descriptions of Chromite Deposits; Bureau of Mines Information Circular 8990, 58 p.

Foley, J.Y., Barker, J.C., and Brown, L.L., 1986, Chromite Resources in Alaska; U.S. Bureau of Mines Information Circular 9087, p. 23-29.

Forbes, R.B., 1974, Garnet-Clinopyrozenite From Red Mountain Pluton, Alaska; Geological Society of America Bulletin v. 85, p. 285-292.

Gill, A.C., 1920, Preliminary Report on the Chromite of Kenai Peninsula; U.S. Geological Survey Bulletin 712, p. 99-129

Gill, A.C., 1922, Chromite of Kenai Peninsula, Alaska; U.S. Geological Survey Bulletin 742, 52 p.

Grant, U.S., and Higgins, D.F., 1910, Preliminary Report on the Mineral Resources of the Southern Part of Kenai Peninsula; U.S. Geological Survey Bulletin 442, p. 166-178.

Gray, J.E., Sanzolone, R.F., 1996, Environmental Studies of Mineral Deposits in Alaska; U.S. Geological Survey Bulletin 2156, 39 p.

Guild, P.W., 1942, Chromite Deposits of Kenai Peninsula, Alaska; U.S. Geological Survey Bulletin 931-G, p. $139-175$.

Huber, Jeff, 1999, Alaska Resource Data File-Seldovia Quadrangle; U.S. Geological Survey Open-File Report 99-391, 70 p.

MacKevett, B.N., Jr., Singer, D.A., and Holloway, C.D., 1978, Maps and Tables Describint Metalliferous Mineral Resource Potential of Southern Alaska; U.S. Geological Survey Open-File Report 78-1-E, 45 p., maps, scale 1:1,000,000.

MacKevett, E.M., Jr., and Holloway, C.D., 1977, Map Summarizing Metalliferous and Selected Nonmetalliferous Mineral Deposits in the Eastern Part of Southern Alaska; U.S. Geological Survey Open-File Report 77-169A; 99 p., 1 sheet, scale 1:1,000,000.

Martin, G.C., 1920, The Alaskan Mining Industry in 1918; U.S. Geological Survey Bulletin 712, p. 11-52.

Martin, G.C., and others, 1915, Geology and Mineral Resources of Kenai Peninsula, Alaska; U.S. Geological Survey Bulletin 587, 243 p.

Mertie, J.B., Jr., 1919, Chromite Deposits in Alaska; U.S. Geological Survey Bulletin 692, p. 265-267.

Moxham, R.M., and Nelson, A.E., 1952, Reconnaissance for Radioactive Deposits in the Southern Cook Inlet Region, Alaska, 1949; U.S. Geological Survey Circular 207, 7 p. 
Nockleberg, W.J., Bundtzen, T.K., Berg, H.C., Brew, D.A., Grybeck, D., Robinson, M.S., Smith, T.E., and Yeend, W., 1987, Significant Metalliferous Lode Deposits and Placer Districts of Alaska; U.S. Geological Survey Bulletin 1786, 104 p.

Rutledge, F.A., 1946, Exploration of Red Mountain Chromite Deposits, Kenai Peninsula, Alaska; Bureau of Mines Report of Investigations 3885, 26 p.

Sanford, R.S., 1944, Red Mountain Chromite Deposits, Kenai Peninsula, Alaska; Bureau of Mines War Minerals Report 191, 51 p.

Sanford, R.S., and Cole, J.W., 1941, Claim Point Chromite Deposits, Kenai Peninsula, Alaska; Bureau of Mines Report of Investigations 4419, $11 \mathrm{p}$.

Sanford, R.S., and Cole, J.W., 1943, Claim Point Chromite Deposits, Kenai Peninsula, Alaska; Bureau of Mines War Minerals Report 253, 34 p.

Smith, P.S., 1933, Mineral Industry of Alaska in 1931; U.S. Geological Survey Bulletin 844-A, p. 1-82.

Smith, P.S., 1934, Mineral Industry of Alaska in 1932; U.S. Geological Survey Bulletin 857-A, p. 1-91.

Smith, P.S., 1936, Mineral Industry of Alaska 1934; U.S. Geological Survey Bulletin 868-A, p. 1-91.

Smith, P.S., 1937, Mineral Industry of Alaska in 1935; U.S. Geological Survey Bulletin 880-A, p. 1-95.

Smith, P.S., 1938, Mineral Industry of Alaska in 1936; U.S. Geological Survey Bulletin 897-A, p. 1-107.

Taylor, C.D., Meier, A.L., and d'Angelo, W.M., 1998, A Reconnaissance Study of the Chemistry of Natural Waters Draining Chromite-Bearing Ultramafic Complexes in Alaska; U.S. Geological Survey Professional Paper 1595, p. 9-16.

Toth, M.I., 1981, Petrology, Geochemistry, and Origin of the Red Mountain Ultramafic Body Near Seldovia, Alaska; U.S. Gelogical Survey Open-File Report 81-0514, 92 p.

Twenhofel, W.S., 1953, Potential Alaska Mineral Resources for Proposed Electrochemical and Electrochemical and Eletrometallurgical Industries in the Upper Lynn Canal Area, Alaska; U.S. Geological Survey Circular 252, 14 p.

U.S. Department of Labor, Mine Safety and Health Administration, 1985, Mine Safety and Health Examinations, 1975-1985.

Wells, R.R., Sterling, F.T., Erspamer, E.G., and Stickney, W.A., 1957, Laboratory Concentration of Chromite Ores, Red Mountain District, Kenai Peninsula, Alaska; Bureau of Mines Report of Investigations 5377, $22 \mathrm{p}$.

Williams, J.A., 1954, Magnetic Exploration of the Red Mountain Chromite Deposit, Kenai, Peninsula; Prospect or Properties Examined, Alaska Territorial Department of Mines PE 104-3, 22 p.

\section{Seward}

Berg, H.C., and Cobb, E.H., 1967, Metalliferous Lode Deposits of Alaska; U.S. Geological Survey Bulletin $1246,254 \mathrm{p}$.

Condon, W.H., and Cass, J.T., 1958, Map of a Part of the Prince William Sound Area, Alaska; Showing Linear Geologic Features as Shown on Aerial Photographs; U.S. Geological Survey Miscellaneous Geologic Investigations Series Map I-273, 1 sheet, scale 1:125,000. 
Kurtak, J.M., 1982, A Manganese Occurrence on Chenega Island, Prince William Sound, Alaska; Bureau of Mines MLA124-82, 9 p.

MacKevett, E.M., Jr., and Holloway, C.D., 1977, Map Summarizing Metalliferous and Selected Nonmetalliferous Mineral Deposits in the Eastern Part of Southern Alaska; U.S. Geological Survey Open-File Report 77-169A, 99 p., 1 sheet, scale 1:1,000,000.

Rutledge, F.A., 1953, Investigation of the Copper Bullion Claims, Rua Cove, Knight Island, Alaska; Bureau of Mines Report of Investigations 4986, 6 p.

Seplocha, S., 1982, Manganese Found on Chenega Island; Anchorage Daily News, 2 p.

Tysdal, R.G., 1979, Mines, Prospects, and Occurrences Map of the Seward and Blying Sound Quadrangles, Alaska; U.S. Geological Survey Miscellaneous Field Studies Map MF-880-A, 2 sheets, scale 1:250,000.

U.S. Department of Labor, Mine Safety and Health Administration, 1985, Mine Safety and Health Examinations, 1975-1985.

\section{Shungnak}

Bain, H.F., 1946, Alaska's Minerals as a Basis for Industry; Bureau of Mines Information Circular 7379, 89 p.

Cobb, E.H., 1972, Metallic Mineral Resources Map of the Shungnak Quadrangle, Alaska; U.S. Geological Survey Miscellaneous Field Studies Map MF-448, 1 sheet, scale 1:250,000.

Heide, H.E., Wright, W.S., and Rutledge, F.A., 1949, Investigation of the Kobuk River Asbestos Deposits, Kobuk District, Northwestern Alaska; Bureau of Mines Report of Investigations 4414, 25 p.

\section{Sitka}

Asbury, D.W., 1964, Vevelstad Copper-Iron Property, Stag Bay; Alaska Division of Geological \& Geophysical Surveys Miscellaneous Report MR-114-10, 3 p.

Bittenbender, P.E., Still, J.C., Maas, K.M., and McDonald, M.E., Jr., 1999, Mineral Resources of the Chichagof and Baranof Islands Area, Southeast Alaska; U.S. Bureau of Land Manangement Technical Report 19, 222 p., 3 sheets, scales 1:63,360 and 1:12,000.

Bundtzen, T.K., Eakins, G.R., and Conwell, C.N., 1982, Review of Alaska's Mineral Resources; Alaska Division of Geological \& Geophysical Surveys and Alaska Department of Commerce and Economic Development.

Cobb, E.H., 1972, Metallic Mineral Resources Map of the Sitka Quadrangle, Alaska; U.S. Geological Survey Miscellaneous Field Studies Map MF-467, 1 sheet, scale 1:250,000.

Flint, G.M., Jr., and Cobb, E.H., 1953, Gypsum Deposits Near Iyoukeen Cove, Chichagof Island, Southeastern Alaska; U.S. Geological Survey Bulletin 989-B, 10 p., 1 sheet, scale 1:4,800.

Gustafson, F.D., 1946, Camel-Gypsum Group (Iyoukeen Cove); Alaska Territorial Department of Mines Miscellaneous Report MR-114-6, 61 p., 3 maps. 
Herreid, G.H., 1962, Camel Gypsum Property (Iyoukeen Cove); Alaska Territorial Department of Mines Prospect Evaluation PE-114-14, 5 p., 1 map.

Jermain, G.D., and Rutledge, F.A., 1952, Diamond Drilling the Gypsum-Camel Prospect, Iyoukeen Cove, Chichagof Island, Southeastern Alaska; Bureau of Mines Report of Investigations 4852, 6 p.

Loney, R.A., Berg, H.C., Pomeroy, J.S., and Brew, D.A., 1963, Reconnaissance Geologic Map of Chichagof Island and Northwestern Baranof Island, Alaska; U.S. Geological Survey Miscellaneous Geologic Investigations Series Map I-388, 7 p., 1 sheet, scale 1:250,000.

Mulligan, J.J., 1974, Mineral Resources of the Trans-Alaska Pipeline Corridor; Bureau of Mines Information Circular 8626, 24 p., 9 sheets, scale 1:190,080.

Stewart, B.D., 1931, Mineral Resources of the Chichagof Island; Alaska Territorial Department of Mines Miscellaneous Report MR-114-3, 5 p.

U.S. Bureau of Mines, 1985, Unpublished data, 1970-1985.

U.S. Department of Labor, Mine Safety and Health Administration, 1985, Mine Safety and Health Examinations, 1975-1985.

\section{Skagway}

Berg, H.C., Decker, J.E., and Abramson, B.S., 1981, Metallic Mineral Deposits of Southeastern Alaska; U.S. Geological Survey Open-File Report 81-122, 145 p., 1 sheet, scale 1:1,000,000.

Bundtzen, T.K., Eakins, G.R., and Conwell, C.N., 1982, Review of Alaska's Mineral Resources; Alaska Division of Geological \& Geophysical Surveys and Alaska Department of Commerce and Economic Development.

Cobb, E.H., 1972, Metallic Mineral Resources Map of the Skagway Quadrangle, Alaska; U.S. Geological Survey Miscellaneous Field Studies Map MF-424, 1 sheet, scale 1:250,000.

Cobb, E.H., 1972, Metallic Mineral Resources Map of the Sumdum Quadrangle, Alaska; U.S. Geological Survey Miscellaneous Field Studies Map MF-425, 1 sheet, scale 1:250,000.

Conwell, C.E., 1970, Palmer Barite Deposit; Alaska Division of Geological \& Geophysical Surveys Prospect Evaluation PE-109-6.

Goldberg, I., Hammerbeck, E.C.I., Labuschagne, L.S., and Rossouw, C., 1992, International Strategic Minerals Inventory Summary Report-Vanadium; U.S. Geological Survey Circular 930-K, 45 p.

Herreid, G.H., 1961, Morey-Quinlan-Tengs Limestone Property (Mile 39, Haines Highway, Klukwan); Alaska Territorial Department of Mines Prospect Evaluation PE-109-4, 6 p., 1 map.

MacKevett, E.M., Jr., 1971, Analyses of Samples and Preliminary Geologic Summary of Barite-SilverBase Metal Deposits Near Glacier Creek, Skagway B-4 Quadrangle, Southeastern; U.S. Geological Survey Open-File Report 71-195, 8 p.

MacKevett, E.M., Jr., Brew, D.A., Hawley, C.C., Huff, L.C., and Smith, J.G., 1967, Mineral Resources of Glacier Bay National Monument, Alaska; U.S. Geological Survey Open-File Report 67-151, 176 p., 10 sheets, 1:125,000. 
MacKevett, E.M., Jr., Robertson, E.C., and Winkler, G.R., 1974, Geology of the Skagway B-3 and B-4 Quadrangles, Southeastern Alaska; U.S. Geological Survey Professional Paper 832, 33 p., 1 sheet, scale $1: 63,360$.

Race, W.H., 1963, H. Stelting Iron Deposit; Alaska Territorial Department of Mines Prospect Evaluation PE-109-5, 7 p.

Robertson, E.C., 1956, Magnetite Deposits Near Klukwan and Haines, Alaska; U.S. Geological Survey Open-File Report 56-101, 37 p., 11 sheets, scales 1:9,000, 1:3,168,000, 1:4,500, 1:600, and $1: 18,000$.

Still, J.C., 1984, Copper, Gold, Platinum, and Palladium Sample Results From the Klukwan Mafic/Ultramafic Complex, Southeast Alaska; Bureau of Mines Open-File Report 21-84, 53 p.

Still, J.C., 1984, Stratiform Massive Sulfide Deposits of the Mt. Henry Clay Area, Southeast Alaska; Bureau of Mines Open-File Report 118-84, 62 p.

U.S. Department of Labor, Mine Safety and Health Administration, 1985, Mine Safety and Health Examinations, 1975-1985.

Wells, R.R., and Thorne, R.L., 1953, Concentration of Klukwan, Alaska, Magnetite Ore; Bureau of Mines Report of Investigations 4984, 15 p.

Williams, J.A., 1956, Alibill No. 2 Claim (Alfred C. Wolk Property); Alaska Territorial Department of Mines Prospect Evaluation PE-109-3, 8 p.

Williams, J.A., 1956, Itinerary Report - Skagway and Haines, April 18 to 20; Alaska Territorial Department of Mines Itinerary Report IR-195-50, 2 p.

\section{Sleetmute}

Bundtzen, T.K., Laird, G.M., and Gilbert, W.G., 1989, Material Studies Along Kuskokwim River, McGrath to Kalskag, Southwest Alaska; Alaska Division of Geological \& Geophysical Surveys Public Data File PDF 89-16, 84 p.

\section{Solomon}

Cobb, E.H., 1972, Metallic Mineral Resources Map of the Solomon Quadrangle, Alaska; U.S. Geological Survey Miscellaneous Field Studies Map MF-445, 1 sheet, scale 1:250,000.

Cobb, E.H., 1978, Summary of References to Mineral Occurrences (Other Than Mineral Fuels and Construction Materials) in the Solomon Quadrangle, Alaska; U.S. Geological Survey Open-File Report 78-181, 185 p.

Hudson, T.L., Miller, M.L., and Peckthorn, W.J., 1977, Map Showing Metalliferous and Selected Nonmetalliferous Mineral Deposits, Seward Peninsula, Alaska; U.S. Geological Survey Open-File Report 77-796-B; 46 p., 1 sheet, scale 1:1,000,000. 


\section{Sumdum}

Barker, J.C., Still, J.C., Mowatt, T.C., and Mulligan, J.J., 1981, Critical and Strategic Minerals in Alaska: Cobalt, the Platinum-Group Metals, and Chromite; Bureau of Mines Information Circular 8869, 8 p., 1 sheet, scale 1:250,000.

Bassett, C.D., 1952, Alaska Iron Ores and Their Available Markets; Alaska Territorial Department of Mines Miscellaneous Report MR-191-6, 5 p.

Brew, D.A., Grybeck, D.J., Johnson, B.R., and Jachens, R.C., 1977, Mineral Resources of the Tracy ArmFords Terror Wilderness Study Area and Vicinity, Alaska; U.S. Geological Survey Open-File Report 77-649, 467 p., 4 sheets, scale 1:125,000.

Cobb, E.H., 1972, Metallic Mineral Resources Map of the Sumdum Quadrangle, Alaska; U.S. Geological Survey Miscellaneous Field Studies Map MF-425, 1 sheet, scale 1:250,000.

Fowler, H.M., 1950, Snettisham Iron Deposit; Alaska Territorial Department of Mines Mineral Investigation MI-115-1, 3 p., 1 map.

Kaufman, A., 1958, Southeastern Alaska's Mineral Industry; Bureau of Mines Information Circular 7844, $37 \mathrm{p}$.

Thorne, R.L., and Wells, R.R., 1956, Studies of the Snettisham Magnetite Deposit, Southeastern Alaska; Bureau of Mines Report of Investigations 5195, 41 p.

U.S. Bureau of Mines, 1985, Unpublished data, 1970-1985.

Williams, J.A., 1952, Snettisham Magnetic Survey; Alaska Territorial Department of Mines Prospect Evaluation PE-115-3, 10 p.

Williams, J.A., 1953, Snettisham Magnetic Survey (Port Snettisham); Alaska Territorial Department of Mines Prospect Evaluation PE-115-5, 25 p.

Williams, J.A., 1955, BBH Property (Endicott Arm); Alaska Territorial Department of Mines Prospect Evaluation PE-115-7, 7 p., 1 sheet, scale 1:480.

\section{Table Mountain}

Barker, J.C., 1981, Mineral Investigations of Certain Lands in the Eastern Brooks Range, 1978; U.S. Bureau of Mines Open-File Report 37-81, 288 p.

Brosge', W.P., and Reiser, H.N., 1977, Lead-Zinc Mineralization at Bear Mountain, Southeastern Brooks Range, in Blean, K.M., ed., The United States Geological Survey in Alaska: Accomplishments During 1976; U.S. Geological Survey Circular, p. B8-B10.

Cobb, E.H., Mayfield, C.F., Brosge, W.P., 1981, Summaries of Data on and Lists of References to Metallic and Selected Non-Metallic Mineral Occurrences in Eleven Quadrangles in Northern Alaska-Summaries of Data to January 1, 1981; U.S. Geological Survey Open-File Report 81-767, 40 p.

Dover, J.H., 1997, Alaska Resource Data File-Table Mountain Quadrangle; U.S. Geological Survey OpenFile Report 97-293, 14 p.

U.S. Geological Survey, 1977, Geological Survey Research, 1977; U.S. Geological Survey Professional Paper, 411 p. 


\section{Talkeetna}

Alaska Department of Revenue, 1985, Mine License Application.

Barker, J.C., Still, J.C., Mowatt, T.C., and Mulligan, J.J., 1981, Critical and Strategic Minerals in Alaska: Cobalt, the Platinum-Group Metals, and Chromite; Bureau of Mines Information Circular 8869, 8 p., 1 sheet, scale 1:250,000.

Bundtzen, T.K., Eakins, G.R., and Conwell, C.N., 1982, Review of Alaska's Mineral Resources; Alaska Division of Geological \& Geophysical Surveys and Alaska Department of Commerce and Economic Development.

Clark, A.L., and Cobb, E.H., 1972, Metallic Mineral Resources Map of the Talkeetna Quadrangle, Alaska; U.S. Geological Survey Miscellaneous Field Studies Map MF-369, 1 sheet, scale 1:250,000.

Cobb, E.H., 1973, Placer Deposits of Alaska; U.S. Geological Survey Bulletin 1374, 213 p., 1 sheet.

MacKevett, E.M., Jr., and Holloway, C.D., 1977, Map Summarizing Metalliferous and Selected Nonmetalliferous Mineral Deposits in the Eastern Part of Southern Alaska; U.S. Geological Survey Open-File Report 77-169A, 99 p., 1 sheet, scale 1:1,000,000.

Mattson, M.J., 1978, Production Statistics of Cache Creek, Yentna District, Talkeetna Quadrangle; Letter to Thad E. Sandford.

Reed, B.L., Nelson, S.W., Curtin, G.C., and Singer, D.A., 1978, Mineral Resources Map of the Talkeetna Quadrangle, Alaska; U.S. Geological Survey Miscellaneous Field Studies Map MF-870-D, 1 sheet, scale 1:250,000.

U.S. Department of Labor, Mine Safety and Health Administration, 1985, Mine Safety and Health Examinations, 1975-1985.

\section{Talkeetna Mountains}

Bundtzen, T.K., Eakins, G.R., and Conwell, C.N., 1982, Review of Alaska's Mineral Resources; Alaska Division of Geological \& Geophysical Surveys and Alaska Department of Commerce and Economic Development.

Cobb, E.H., 1972, Metallic Mineral Resources Map of the Taku River Quadrangle, Alaska; U.S. Geological Survey Miscellaneous Field Studies Map MF-407, 1 sheet, scale 1:250,000.

Hawkins, D.B., 1976, Commercial-Grade Mordenite Deposits of the Horn Mountains, South-Central Alaska; Alaska Division of Geological \& Geophysical Surveys Special Report 11, 11 p.

Hawkins, D.B., 1988, A Potential Economic Mordenite Deposit Talkeetna Mountains, Alaska; Occurance, Properties, and Utilization of Natural Zeolites, August 12-16, 1985, p. 19-28.

\section{Tanacross}

Alaska Department of Revenue, 1982, Mine License Application. 
U.S. Department of Labor, Mine Safety and Health Administration, 1985, Mine Safety and Health Examinations, 1975-1985.

\section{Tanana}

Brooks, A.H., and others, 1911, Mineral Resources of Alaska: Report of Progress of Investigations in 1910; U.S. Geological Survey Bulletin 480, 333 p, 1 sheet, scale 1:5,000,000.

Bundtzen, T.K., Eakins, G.R., and Conwell, C.N., 1982, Review of Alaska's Mineral Resources; Alaska Division of Geological \& Geophysical Surveys and Alaska Department of Commerce and Economic Development.

Cobb, E.H., 1972, Metallic Mineral Resources Map of the Tanana Quadrangle, Alaska; U.S. Geological Survey Miscellaneous Field Studies Map MF-371, 1 sheet, scale 1:250,000.

Cobb, E.H., 1973, Placer Deposits of Alaska; U.S. Geological Survey Bulletin 1374, 213 p., 1 sheet.

Eberlein, G.D., Chapman, R.M., Foster, H.L., and Gassaway, J.S., 1977, Map and Table Describing Known Metalliferous and Selected Nonmetalliferous Mineral Deposits in Central Alaska; U.S. Geological Survey Open-File Report 77-168-D, 131 p., 1 sheet, scale 1:1,000,000.

Plafker, G., and MacKevett, E.M., Jr, 1969, Mafic and Ultramafic Rocks From a Layered Pluton at Mt. Fairweather, Alaska; U.S. Geological Survey Open-File Report. 69-208, 10 p.

Saunders, R.H., 1957, Salt Creek Asbestos Deposit; Alaska Territorial Department of Mines Miscellaneous Report MR-48-5, 4 p.

Thomas, B.I., 1957, Tin-Bearing Placer Deposits Near Tofty, Hot Springs District, Central Alaska; Bureau of Mines Report of Investigations 5373, 56 p.

Thomas, B.I., 1965, Reconnaissance Sampling of the Avnet Manganese Prospect, Tanana Quadrangle, Central Alaska; Bureau of Mines Open-File Report 10-65, 8 p.

Thorne, R.L., and Wright, W.S., 1945, Sullivan Creek Tailings, Manley Hot Springs, Tofty, Alaska—Tin; Bureau of Mines War Minerals Report 467, 9 p.

Thorne, R.L., and Wright, W.S., 1948, Sampling Methods and Results at the Sullivan Creek Tin Placer Deposits, Manley Hot Springs, Tofty, Alaska; Bureau of Mines Report of Investigations 4346, 8 p.

U.S. Bureau of Mines, 1985, Unpublished data, 1970-1985.

Warner, L.A., Goddard, E.N., and others, 1961, Iron and Copper Deposits of Kasaan Peninsula, Prince of Wales Island, Southeastern Alaska; U.S. Geological Survey Bulletin 1090, 136 p., 28 sheets, scale $1: 63,360$.

Wayland, R.G., 1961, Tofty Tin Belt, Manley Hot Springs District, Alaska; U.S. Geological Survey Bulletin 1058-I, 51 p., 2 sheets, scales 1:96,000 and 1:24,000.

\section{Teller}

Berg, H.C., and Cobb, E.H., 1967, Metalliferous Lode Deposits of Alaska; U.S. Geological Survey Bulletin $1246,254 \mathrm{p}$. 
Cobb, E.H., and Sainsbury, C.L., 1972, Metallic Mineral Resources Map of the Teller Quadrangle, Alaska; U.S. Geological Survey Miscellaneous Field Studies Map MF-426, 1 sheet, scale 1:250,000.

Heide, H.E., 1943, Lost River Mines, Seward Peninsula, Alaska-Tin; Bureau of Mines War Minerals Report 45, 9 p.

Hudson, T.L., Miller, M.L., and Peckthorn, W.J., 1977, Map Showing Metalliferous and Selected Nonmetalliferous Mineral Deposits, Seward Peninsula, Alaska; U.S. Geological Survey Open-File Report 77-796-B, 46 p., 1 sheet, scale 1:1,000,000.

Killeen, P.L., and Ordway, R.J., 1955, Radioactivity Investigations at Ear Mountain, Seward Peninsula, Alaska, 1945; U.S. Geological Survey Bulletin 1024-C, 35 p.

Lorain, S.H., Wells, R.R., Mihelich, M., Mulligan, J.J., Thorne, R.L., and Herdlick, J.A., 1958, Lode-Tin Mining at Lost River, Seward Peninsula, Alaska; Bureau of Mines Information Circular 7871, 76 p.

Lost River Mining Corporation, Ltd. (Toronto), 1972, Annual Report, 1972; Lost River Mining Corporation Ltd, 15 p.

Mulligan, J.J., 1959, Sampling Stream Gravels for Tin, Near York, Seward Peninsula, Alaska; Bureau of Mines Report of Investigations 5520, 25 p.

Mulligan, J.J., 1959, Tin Placer and Lode Investigations, Ear Mountain Area, Seward Peninsula, Alaska; Bureau of Mines Report of Investigations 5493, 53 p.

U.S. Bureau of Mines, 1945, Imuruk Basin, Seward Peninsula, Alaska-Graphite; Bureau of Mines Draft Preliminary War Minerals Report 4501.

Williams, J.A., and Saunders, R.H., 1953, Lost River Geophysical Work--Tin Deposit; Alaska Territorial Department of Mines Prospect Evaluation PE-43-2, 21 p., 5 sheets, scale 1:1,200.

Williams, J.A., and Saunders, R.H., 1954, Magnetic Exploration of Cape Mountain Placer Tin Deposits; Alaska Territorial Department of Mines Prospect Evaluation PE-43-3, 15 p., 6 maps, scale $1: 2,400$.

\section{Tyonek}

Cobb, E.H., 1972, Metallic Mineral Resources Map of the Tyonek Quadrangle, Alaska; U.S. Geological Survey Miscellaneous Field Studies Map MF-385, 1 sheet, scale 1:250,000.

\section{Unalaska}

U.S. Bureau of Mines, 1945, Proposed Investigation of Mineral Deposits on Alaska Peninsula and Aleutian Islands; Bureau of Mines Draft Preliminary War Minerals Report 4503.

\section{Valdez}

Berg, H.C., and Cobb, E.H., 1967, Metalliferous Lode Deposits of Alaska; U.S. Geological Survey Bulletin 1246; 254 p. 
Bundtzen, T.K., Eakins, G.R., and Conwell, C.N., 1982, Review of Alaska's Mineral Resources; Alaska Division of Geological \& Geophysical Surveys and Alaska Department of Commerce and Economic Development.

Cobb, E.H., and Matson, N.A., Jr., 1972, Metallic Mineral Resources Map of the Valdez Quadrangle, Alaska; U.S. Geological Survey Miscellaneous Field Studies Map MF-438, 1 sheet, scale $1: 250,000$.

MacKevett, E.M., Jr., and Holloway, C.D., 1977, Map Summarizing Metalliferous and Selected Nonmetalliferous Mineral Deposits in the Eastern Part of Southern Alaska; U.S. Geological Survey Open-File Report 77-169A, 99 p., 1 sheet, scale 1:1,000,000.

Mulligan, J.J., 1974, Mineral Resources of the Trans-Alaska Pipeline Corridor; Bureau of Mines Information Circular 8626, 24 p., 9 sheets, scale 1:190,080.

Nichols, D.R., and Yehle, L.A., 1969, Engineering Geologic Map of the Southwestern Copper River Basin, Alaska; U.S. Geological Survey Miscellaneous Geologic Investigations Series Map I-524, 1 sheet, scale $1: 2,500,000$.

U.S. Department of Labor, Mine Safety and Health Administration, 1985, Mine Safety and Health Examinations, 1975-1985.

\section{Wiseman}

Brosge, W.P., and Reiser, H.N., 1960, Progress Map of the Geology of the Wiseman Quadrangle, Alaska; U.S. Geological Survey Open-File Report 60-19, 3 sheets, scale 1:250,000.

Mulligan, J.J., 1974, Mineral Resources of the Trans-Alaska Pipeline Corridor; Bureau of Mines Information Circular 8626, 24 p., 9 sheets, scale 1:190,080.

\section{Yakutat}

Cobb, E.H., 1972, Metallic Mineral Resources Map of the Yakutat Quadrangle, Alaska; U.S. Geological Survey Miscellaneous Field Studies Map MF-408, 1 sheet, scale 1:250,000.

Cobb, E.H., 1973, Placer Deposits of Alaska; U.S. Geological Survey Bulletin 1374, 213 p., 1 sheet.

MacKevett, E.M., Jr., and Holloway, C.D., 1977, Map Summarizing Metalliferous and Selected Nonmetalliferous Mineral Deposits in the Eastern Part of Southern Alaska; U.S. Geological Survey Open-File Report 77-169A; 99 p., 1 sheet, scale 1:1,000,000.

Miller, D.L., 1961, Geology of the Yakutat District, Gulf of Alaska Tertiary Province, Alaska; U.S. Geological Survey Open-File Report 61-103, 2 sheets, scale 1:96,000. 